
- 



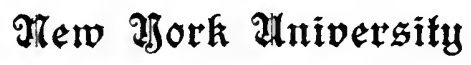
Ottendorfer Sertes of Eermanic Monographs To. 4.

\section{HEYSE AND HIS PREDECESSORS IN THE THEORY OF THE NOVELLE}

Robert McBurney Mitchell, Ph. D.

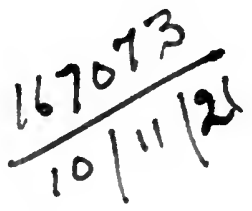

Frankfurt a. $M$.

Joseph Baer \& Co. 

Arsens

$\rightarrow$ 
Dem Andenken Oswald Ottendorfers 


\section{CONTENTS.}

Introduction . . . . . . . . . . . . . . . . . . . . 1

I. Naturalization of the Word Novelle: 1523-1798 . . . . . . 3

II. Theory of the Novelle from the Schlegels to Young Germany: 1798-1834 . . . . . . . . . . . . . . . . . . . . . 8

III. Theory of the Novelle from Young Germany to Heyse: 1834-1871 44

IV. Heyse's Theory of the Novelle: 1871-1912 . . . . . . . . . 76

Conclusion . . . . . . . . . . . . . . . . . . . . . 101 


\section{Introduction.}

Of the four acknowledged masters of the novelle in Germany - Theodor Storm, Paul Heyse, Gottfried Keller and Conrad Ferdinand Meyer - Heyse alone has expressed himself with any considerable fullness on the theory of this literary species. Just as in America Edgar Allen Poe's theory of the short story - or short-story, to follow a happy suggestion of Professor Brander Matthews ${ }^{1}$ ) - has met with universal acceptance and appreciation, so in Germany Heyse's famous "Falcon Theory" has met with general approval as being by all odds the best and clearest statement on the theory of the novelle. But Heyse's position in the historical development of this theory in Germany is quite different from that of Poe in America. Poe was the first American critic to point out the fact that the short-story is a distinct genre in literature with certain specific laws governing its composition, and American and English criticism still accepts this norm with little or no modification. Heyse on the contrary may be said to have closed a long discussion which had gone on intermittently for three quarters of a century in Germany, and which in its beginnings antedates Poe by nearly half a century.

It is the purpose of the present investigation to trace the development of the theory of the novelle in Germany from its beginnings to what is, for the present at least, its culmination in Heyse's justly famous critical statement. In the course of the investigation the fact has become constantly more evident that

1) "I have written 'Short-stories' with a capital S and a hyphen because I wished to emphasise the distinction between the Short-story and the story which is merely short." The Philosophy of the Short-story, New York I901, pp. $25-26$. 
the terms novelle and short-story are by no means synonymous, and so the term novelle has been used throughout to designate the literary species under discussion ${ }^{1}$ ). English terminology still lacks an appropriate name for what has been called the "long short-story", exemplified in Hale's The Man Without a Country, which in Germany would pass unquestioned as a novelle.

American criticism in particular has too often made the mistake of approaching the briefer prose tales of Italy, France and Germany with prejudices in favor of the standard set by Poe, and has stood embarassed before stories of evident literary excellence which refuse to measure up (or down) to the Poe norm ${ }^{2}$ ). By carefully tracing the theory of the novelle in its historical development there are brought to light subtile and far reaching differences in essentials between the novelle and the short-story. The two are evidently closely related, yet distinct, literary forms. It is to be hoped that the Romance novella, nouvelle and conte will eventually be subjected to a scrutiny similar, perhaps, to that attempted here for the novelle, that we may gain a clearer picture of the relation which these various forms bear to one another, in their family resemblances as well as in their individual differences.

1) To note only a single striking difference: the short-story is a form which imperatively demands extreme brevity and compactness, while for the novelle this has never been more than a minor consideration. This and other differences have already been pointed out: cf. Paul Bastier, La Nouvelle individualiste en. Allemagne, Paris 1910, p. 46, and especially the review of this book by Prof. Camillo von Klenze, Journal of Eng. and Germ. Philology, XI (1912) 113. note; also R. M. Mitchell, Poe and Spielhagen; Novelle and Short-story, Mod. Lang. Notes, Feb. I9I4. Indicative of the German attitude toward the technic. of the short-story is a phrase of R. M. Meyer: "Ubung im Zusammenschieben, wie sie durch die short-story aufkam". Die deutsche Lit. des 19. Fhdts. 3. Aufl., 1906, p. 845 .

2) Cf., e. g., C. S. Baldwin, Studies out of Hours, New York 1907. pp. I10-161: Three Studies in the Short Story. Here Prof. Baldwin in a careful analysis of the hundred tales of the Decamerone finds only two that can be classified as short-stories. With the exception of a few, which are obviously mere anecdotes, these tales pass unchallenged in Germany as novellen. 


\section{Nataralization of the Word Novelle: 1523-1798.}

Among literary forms in Germany the novelle is one of the youngest. Before the beginning of the Igth century the word novelle in its German form is of extremely rare occurrence. It is found almost exclusively in the plural form, it is used practically without exception only with reference to foreign literatures and is almost invariably accompanied by some attempt at explanation or definition. This slow process of naturalization is most interesting to follow, as well for its bearing upon the beginnings of the theory of the novelle in Germany as for its indication of the foreign model and inspiration for the native product, all in corroboration of the etymology of the name. Before the last half of the I8th century the word is found only in the foreign form. Pamphilius Gengenbach adds to the title of his Novella (1523) an implicit definition:

Waer jemantz der new maer begaert

Der wirt in disem buechlin gewaert.

Er wirt hoeren groß obenthür

Die do kurtzlich ist gangen für $\left.{ }^{\mathbf{1}}\right)$.

The Strassburg translation of the Decameron (I535) also suggests a German equivalent for the Italian novella in the title: Decameron, das ist cento novelle in welsch und hundert histori oder neve fabel in teutsche $e^{2}$. Here in both cases, just as in the Italian form, the German translation accentuates the element of novelty.

A transitional form, a compromise between the foreign and the native, is the word Nouvellenschreiberin coined by Lessing (I759), in his Briefe die neueste Literatur betreffend, III, 53, with reference to a French writer, Mme. Gillot de Sainctonge $^{3}$ ). And we must look again to Lessing for what is probably the first use of the word novelle in the singular form. Incidentally

1) Karl Goedeke, Pamphilius Gengenbach. Ein Beitrag zur deutschen Literaturgeschichte der Reformationszeit. Hannover I855, 262 ff.

$\left.{ }^{2}\right)$ Cf. Grimms Wörterbuch, VII, 966, under Novelle.

$\left.{ }^{3}\right)$ Lessing, Sämtliche Schritten, hrsg. von Lachmann-Muncker, VIII, I 59. 
he gives us here also the first hint of any feeling for the close relationship existing between the drama and the novelle, a point highly stressed by many modern theorists. In the Hamburgische Dramaturgie, 2. Bd., 54. Stück (6. Nov. 1767), he writes: „Banks [Verfasser des Trauerspiels „Der unglückliche Liebling, oder Graf von Essex", 1682] scheinet keinen von seinen französischen Vorgängern gekannt zu haben. Er ist aber einer N o v e 11 e gefolgt, die den Titel, Geheime Geschichte der Königin Elisabeth und des Grafen von Essex (The Companion to the theatre, II, 99) führet, wo er den ganzen Stoff sich so in die Hände gearbeitet fand, daß er ihn bloß zu dialogisieren, ihm bloß die äußere dramatische Form $z u$ erteilen brauchte ${ }^{\text {(1) }}$ ).

Three years earlier in his Don Sylvio von Rosalva (I764) Wieland mentions ,die Arabischen und Persianischen Erzählungen, und die $\mathrm{N}$ ovelle n und Feenmärchen" 2 ), and this is probably the first use of the native form of the word in German literature. But it is evident that the term novelle, is not in familiar use for he hastens to add in a lengthy footnote: „Novellen werden vorzüglich eine Art von Erzählungen genannt, welche sich von den großen Romanen durch die Simplicität des Plans und den kleinen Umfang der Fabel unterscheiden, oder sich zu denselben verhalten, wie die kleinen Schauspiele zu der großen Tragödie und Comödie. Die Spanier und Italiener haben derer eine unendliche Menge. Von jenen sind die Novellen des Cervantes durch die französische Übersetzung und durch eine deutsche Übersetzung der französischen bekannt. Sie sind ihres Verfassers nicht unwürdig. Von den Italienischen hat man uns zu Venedig 1754 einen Auszug unter dem Titel Il Novelliere It a liano in vier Oktavbänden geliefert, der nicht weniger als I77 Novellen von mehr als acht und zwanzig verschiedenen Verfassern enthält. Die meisten sind Nachahmer des durch seinen Dekamerone so berühmten Boccaccio. Auch die Franzosen haben, seitdem die bekannte Mad. de Ville-dieu diese Art von kleinen Romanen beliebt gemacht hat, eine Menge Werkchen dieser Art aufzuweisen, wovon die Besten in der Bibliothèque de Campagne zu finden sind ${ }^{\text {“3 }}$ ).

1) op. cit. $X, 8$.

2) Wieland, Don Sylvio von Rosalva, Karlsruhe $1777-80$, I $8 \mathrm{f}$.

3) loc. cit. $18 \mathrm{f}$. 
A generation later in the title Novelle ohne Titel (I805) Wieland uses the term without apology for its foreign origin despite the fact that this must have been one of the earliest occasions of its use on a titlepage $\mathbf{1}^{\mathbf{1}}$. This first considerable attempt at a definition here in Don Sylvio is also the first faltering step toward a clear distinction between roman and novelle. The expressions "Simplicität des Plans" and, in a certain sense, even ,kleinen Umfang der Fabel“ point in the right direction, but Wieland characteristically chooses the broad and easy way and ends lamely with , diese Art von kleinen Romanen“, utterly failing to pierce to the essence of the matter. In his reference to the drama Lessing hints at an essential similarity of genre, but for Wieland the comparison is purely quantitative.

Wieland's note on the novelle shows, too, how dependent on foreign models any attempt at a definition or a theory at this time in Germany must necessarily have been. In the chap-books and folk tales, in Meißner's Skizzen (I778-96) and Goethe's Unterhaltungen deutscher Ausgewanderten (1795), the modern student of literature sees the beginnings of the German novelle distinctly enough, but during the last quarter of the I8th century these stories and their like were simply ignored by serious critics. Johann Jakob Engel in his Anfangsgrïnde einer Theorie der Dichtungsarten aus deutschen Mustern entwickelt (Berlin 1783 , 2. Aufl. I804), except for an excursus on the fable, disregards the prose tale entirely, just as earlier (I774) in his Fragmente über Handlung, Gespräch und Erzählung ${ }^{2}$ ) he had dealt with the art

1) Bernhard Seuffert, in his article on Goethes Novelle in the GoetheFahrbuch, XIX (1898) I 33 ff., claims that the word novelle after I 795 „,vereinzelt auf Büchertiteln zu erscheinen beginnt". I have found nothing earlier than Wieland's Novelle ohne Titel (1805), with the single exception of Karl Grosse's Des Grafen von Vargas Novellen, Berlin I792. It is worthy of note that Blankenburg in his Zusätze zu Sulzers allg. Theorie der schönen Künste (1796), cited by Seuffert, mentions nothing of the sort in a long list of German tales in prose and verse. The same is true of Sulzer's $3 \mathrm{~d}$ edition, 1798 , which brings the list down to date. Goedeke lists a few titles, but it is not clear in most cases whether the word novelle actually appears on the title page.

2) J. J. Engel, Schriften, Berlin 1801-06, IV, 101-266. 
of narration and not with the erzählung as a literary form. Johann Joachim Eschenburg, the friend of Wieland and collaborator on the Shakespeare translation, in his Entwourf einer Theorie und Litteratur der schönen Wissenschaften (Berlin und Stettin I783), also lays the emphasis almost exclusively on verse as opposed to prose. Indeed it appears that prose fiction had as yet scarcely attained to the dignity of being ranked as literature. After defining novels as ,,größere Erzählungen, deren Stoff mannigfaltiger und ergiebiger, und deren Ausführung umständlicher ist" (p. 265), Eschenburg begins an apology for the novel with the words: „Man sieht aus diesem allen, daß man die Romane gewissermaßen auch als eine poetische Gattung ansehen kann" (p. 267).

This same apologetic note runs through the preface to the first German theory of the novel, Chr. Fr. von Blankenburg's Versuch über den Roman (Leipzig und Liegnitz I774): „Vielleicht hat man es nicht der Mühe werth gehalten, über eine Gattung von Schriften viel nachzudenken, die nur für die Unterhaltung der Menge geschrieben ist . . . . I Ich glaube, ein Roman könne zu einem sehr angenehmen und sehr lehrreichen Zeitvertreibe dienen und nicht etwan für müßige Frauenzimmer, sondern auch für den denkenden Kopf ..... . Ich sehe den Roman, den g u t e $\mathrm{n} \mathrm{R}$ o m a n, für das an, was, in den ersten Zeiten Griechenlands, die Epopee für die Griechen war; wenigstens glaub' ich's, daß der g u te R o m a n für uns das werden könne." Such was the attitude of the ablest critics of the day in the face of the English novelists and Rousseau abroad and Agathon and Werther at home. Small wonder then, with the novel thus in disrepute, that the prose tale should meet with scant consideration. Eschenburg's attempt to differentiate here between prose and verse is interesting in showing what demands were made upon the erzählung in either form: „Die poetische Erzählung stimmt mit der prosaischen darin überein, da $\mathrm{B}$ beyde den Vortrag einer bestimmten Handlung oder Begebenheit enthalten. Nur darin liegt ihr Unterschied, daB man bey der prosaischen Erzählung bloß auf Wahrheit oder Wahrscheinlichkeit, Deutlichkeit, Ordnung, Kürze und Vollständigkeit zu sehen hat, da bey der poetischen hingegen, außer diesen Eigenschaften, auch die möglichst vollkommene sinnliche Darstellung 
der Handlung oder Begebenheit erfordert wird" (p. 55). Here there is no attempt to distinguish between the tale and the novel (the latter, indeed, is nowhere mentioned) unless it be implicit in the word „Kürze“ or in the (properly emphasized) ,Votrag e i n e r bestimmten Handlung oder Begebenheit". In the subsequent treatment of the tale in verse the prose tale is passed over in silence. Incidentally mention is made of the ,kleinere prosaische Erzählungen oder Novellen" of the Italians and of the ,Novellensammlung", Cento novelle antiche (p. 270). But there is no hint that the term novelle might be used in connection with anything German. Blankenburg in his Literarische Zusätze zu Johann George Sulzers allgemeiner Theorie der schönen Künste (3 Bde., Berlin I796-98) in the article Erzählung uses the plural form „Novellen" repeatedly ( $\mathrm{x} 6$ times) but always exclusively of Italian and Spanish collections of stories $^{1}$ ). This article is entirely bibliographical and nowhere attempts a definition of erzählung ${ }^{2}$ ) or novelle, except tentatively in the distinction drawn between the earliest prose tales in France and ,die sogenannten, eigentlichen $\mathrm{N}$ o u v e $11 \mathrm{e} \mathrm{s}$, welche gegen die Mitte des siebzehnten Jahrhundertes Mode wurden. Sie zeichnen, von den angeführten, kürzern und fröhlichern oder auch traurigern, sich durch größere Umständlichkeit, durch mehrere Entwickelung des Inhaltes, durch mehr Ernst, oder Feyerlichkeit im Tone aus; es sind wirkliche kleine Romane; und, wahrscheinlicher Weise sind die vorher angeführten Spanischen Erzählungen, im Ganzen, ihr Muster gewesen"3). Blankenburg, like Wieland, finds the difference between novelle and roman to be mainly quantitative. So too the Nachträge zu Sulzers allgemeiner Theorie der schönen Künste... von einer Gesellschaft von Gelehrten (Leipzig 1792)

$\left.{ }^{1}\right)$ Seuffert, op. cit. 133 , is mistaken in finding here the first use of the word Novellen.

$\left.{ }^{2}\right)$ The article Erzählung in the 3d ed. of Sulzer's Allg. Theorie der schönen Künste, Frankfurt and Leipzig 1798, was repeated from the earlier editions without change except for the addition of Blankenburg's bibliography from the Zusätze. This article deals exclusively with the tale in verse except for a closing paragraph on Arabic „Erzählungen" and „Contes“.

3) Sulzer, op. cit., 3d ed. I798, II, I54. 
had stated: „Der Roman ist eine erdichtete Erzählung von größerem Umfang. Durch diesen größern Umfang ist er leicht von den kleinern Erdichtungen zu unterscheiden, die man besonders Erzählungen zu nennen pflegt." (I, 38).

\section{Theory of the Novelle, from the Schlegels to Young Germany: $1798-1834$.}

Up to the close of the r8th century it would seem then that no theory for the brief prose tale had been developed in Germany. The term novelle is used exclusively with reference to foreign literatures, and here but sparingly; erzählung is the term used to cover all prose fiction except the novel ${ }^{1}$ ), and there is no hint that any but a quantitative difference between these two forms was perceived, though they have since come to be so sharply differentiated. For one particular case Lessing points to the affinity between novelle and drama, but before the Schlegels there is no attempt to set off the novelle as an independent literary genre or to formulate its theory definitely. Just at the close of the century, however, we come upon a hint regarding the direction which the development of the theory of the novelle is to take. Two years after the appearance of Blankenburg's Zusätze (I796) A. W. Schlegel in the Athenaeum Fragments writes: „Wie die Novelle in jedem Punkt ihres Seyns und ihres Werdens neu und frappant seyn muß, so sollte vielleicht das poetische Mährchen und vorzüglich die Romanze unendlich bizarr seyn; denn sie will nicht bloß die Fantasie interessieren, sondern auch den Geist bezaubern und das Gemüth reizen; und das Wesen des Bizarren scheint eben in gewissen willkürlichen und seltsamen Verknüpfungen und Verwechselungen des Denkens, Dichtens und Handelns zu bestehen“'2). We have here not only the theory of the Schlegels in nuce but also a distinct foreshadowing of the lines along which the novelle

1) Eschenburg (p. 63) and Sulzer (3d ed., II, 129) distinguish between „kurze Erzählung“ and „äsopische Fabel“, but both have reference only to the tale in verse. Eschenburg includes allegory under the caption „poetische Erzählung".

2) Athenaeum, I (1798), 2. Stück, p. 139. 
of German Romanticism was to develop, for what is said of the nature of the bizarre applies quite as well to that element in the Romantic novelle as to the romanze. That the theme of the novelle must be novel and striking is also the essence of Heyse's theory; indeed this dictum is valid to the present day for the best productions in this field.

Though in general so lacking in definite sense of external form, the German Romanticists nevertheless did the novelle good service even on the strictly technical side. In their aversion from an uncongenial present their search for a more congenial past fortunately led them directly to the two great masters of form in medieval Romance prose ${ }^{\mathbf{1}}$ ), to Cervantes and to Boccaccio, whose genius had come to happiest expression in the novelle. In sharpest contrast with the formlessness of the I8th century prose tale in Germany, which in the work of Jean Paul had wellnigh broken with any sort of formal restraint, was the clear-cut cameo technic of the Decamerone. To the theorists among the Romanticists the fact was patent that the conscious art of Boccaccio had here created a new literary species. The new literary movement was searching for a new form of expression. Characteristic of the movement was a love of the miraculous, the marvellous, as opposed to the real and actual. Characteristic of the Romance novella and its forebears back to the days of the Pharaohs $^{2}$ ) was a decided preference for the marvellous, unusual, unique, in choice of subject, for the novella is strictly oral in its origin and must hold the attention of the listener at any cost. Now the Romantic love of miracle (,,das Wunder") was essentially lyric and subjective, while the element of the marvellous or unusual in the Romance novella was essentially epic and objective ${ }^{3}$ ). This

1) Medieval, that is, in the Romantic sense, for both belong to the Renaissance.

2) Cf. Alfred Wiedemann, Altägyptische Sagen und Märchen (Der Volksmund, Bd. VI), Leipzig 1906; G. Maspero, Les Contes populaires de l'Egypte ancienne, zième éd., Paris 1905.

3) Cf. Paul Bastier, op. cit., p. 59. This is doubtless one reason why German Romanticism produced next to nothing of lasting value in this particular field. There are, however, exceptions like Brentano's Geschichte vom 
distinction apparently was not felt by the German Romanticists; at any rate it constituted no hindrance to the enthusiastic acceptance of the new genre. The affinity between the miraculous and the unusual, unique, was sufficient to overshadow all technical dissimilarities of literary treatment. And so it is not surprising that Friedrich Schlegel proceeded to the analysis of the Italian novella strictly on the basis of preconceptions in harmony with the German Romantic movement.

He devotes the closing paragraphs of his Nachricht von den poetischen Werken des Johannes Boccaccio, $\mathrm{I}^{80 \mathrm{I}^{\mathbf{1}}}$ ), to an attempt at a general characterization of the new genre which results in little else than a confession of faith in the subjective in art. From the peculiar visual angle of Romanticism he finds: ,.. . . . die Novelle ist sehr geeignet, eine subjektive Stimmung und Ansicht, und zwar die tiefsten und eigentümlichsten derselben, indirekt und gleichsam sinnbildlich darzustellen"'2). $\mathrm{He}$ points out that Cervantes' personality shines through the best of his Novelas exemplares just as does Shakespeare's in the dramatized novelle, Romeo and Juliet, and continues: „Auch bedarf es keiner Auseinandersetzung, um zu zeigen, daß diese indirekte Darstellung des Subjektiven für manche Fälle angemessener und schicklicher sein kann, als die unmittelbare lyrische, ja $\mathrm{da} B$ gerade das Indirekte und Verhüllte dieser Art der Mitteilung ihr einen höheren Reiz leihen mag. Auf ähnliche Weise ist die Novelle selbst $\mathrm{zu}$ dieser indirekten und verborgenen Subjektivität vielleicht eben darum besonders geschickt, weil sie übrigens sich sehr zum Objektiven neigt...."3).

braven Kasperl und dem schönen Annerl. Kleist's rare sense of form gives him a place apart though his work falls within this same period.

1) The essay has been published four times: I. A. W. nnd Fr. Schlegel, Charakteristiken und Kritiken, 2 Bde., Königsberg 1801, II, 360-400. 2. Fr. Schlegel, Sämtliche Werke, Wien 1825 ff., X, 3-36. 3: Fr. von Schlegel, Sämtliche Werke, 2. Original-Ausgabe, Wien 1846, VIII, 5-29. 4. J. Minor, Fr. Schlegel 1794-1802: seine prosaischen Fugendschriften, 2 Bde., Wien 1882, II, 396-414, from which I here quote.

') Minor, II, 4II.

s) loc. cit. 4 I 2 . 
A subjectivity which consists in nothing more than an indication of the poet's personal leanings in his choice of subject is quite as characteristic of Homer as of Shakespeare, two classic examples of absolute objectivity in literature. In this sense the novelle, typically the extreme of objectivity, as Schlegel admits, may be conceded to be subjective. But the author of Lucinde is naturally not content with a subjectivity of this nature: „Es werden sich ihm [dem Erzähler] eine große Menge [Geschichten] darbieten, die etwas objektiv Merkwürdiges und mehr oder weniger allgemein Interessantes haben. Was anders soll die Auswahl aus der Menge bestimmen, als die subjektive Anneigung, die sich allemal auf einen mehr oder minder vollkommenen Ausdruck einer eigenen Ansicht, eines eigenen Gefühles gründen wird? Und welchem Erzähler einzelner Geschichten ohne innern, weder historischen noch mythischen Zusammenhang, würden wir wohl lange mit Interesse zuhören, wenn wir uns nicht für ihn selbst $\mathrm{zu}$ interessieren anfingen? Man isoliere diese natürliche Eigenheit der Novelle, man gebe ihr die höchste Kraft und Ausbildung, und so entsteht jene . . . . A Art derselben, die ich die allegorische nennen möchte, (in welcher sich das subjektive Gefühl in seiner ganzen Tiefe ausspricht,) und die wenigstens, mag man sie so oder anders bezeichnen wollen, sich immer als der Gipfel und die eigentliche Blüte der ganzen Gattung bewähren 'wird'1)“"

It is evident that the critic is here speaking strictly pro domo and is only incidentally concerned with establishing the nature and boundaries of a literary form. However he does attempt a definition: „Es ist die Novelle eine Anekdote, eine noch unbekannte Geschichte; so erzählt, wie man sie in Gesellschaft erzählen würde, eine Geschichte, die an und für sich schon einzeln interessieren können muß, ohne irgend auf den Zusammenhang der Nationen oder der Zeiten, oder auch auf die Fortschritte der Menschheit und das Verhältnis zur Bildung derselben zu sehen. Eine Geschichte also, die streng genommen, nicht zur Geschichte gehört, und die Anlage zur Ironie schon in der Geburtsstunde mit

1) loc. cit. 413. The parenthesis is added from the version in the Sämtliche Werke (1825 ff.). 
auf die Welt bringt. Da sie interessieren soll, so muß sie in ihrer Form irgend etwas enthalten, was vielen merkwürdig oder lieb sein zu können verspricht" ${ }^{\prime 1}$ ).

First of all the story should be new. But Boccaccio retells many a tale that had long been common property, and Schlegel is forced to seek an alternative: „Der andere Weg, der sich dem künstlichern Erzähler, dem vielleicht die ersten Blüten schon vorweggenommen sind, zeigt, ist der, daß er auch bekannte Geschichten durch die Art, wie er sie erzählt und vielleicht umbildet, in neue zu verwandeln scheine. “2) Novelty then, either in subject or in treatment, is a prime requisite, whether the plot be old or new. The story must interest the listener in any event, and the form of the telling must be shaped to this end. The differentiation between fiction and historic fact seems to be either reiteration of the demand for novelty or, it may be, an indistinct foreshadowing of his brother A. W. Schlegel's distinction between political history and the "Geschichte außer der Geschichte“ which occurs „gleichsam hinter dem Rücken der bürgerlichen Verfassungen und Anordnungen" and depends on the novelle for its recording ${ }^{3}$ ). There is, too, a hint of the oral origin and tradition of the species: the story should be told in the manner of the raconteur in company, the homo facetus of the Renaissance. This idea is met with occasionally in the work of later theorists; in practice the vast majority of frame stories (rahmenerzählungen) are essentially nothing more than the introduction of the raconteur and his one or more auditors. In this connection Schlegel emphasizes the fact that the species has its origin in cultivated society ${ }^{4}$ ), and we should hardly be straining the point to see in this a tacit endeavor to distinguish between the popular tale (fabliau, schwank, märchen etc.) and the more highly developed novelle.

1) loc. cit. 412 .

$\left.{ }^{2}\right)$ loc. cit. 413.

3) See below, p. 16 and note 2 .

4) loc. cit 412: , . . . wiewohl sie [die Novelle] das Lokale und das Kostüm gerne mit Genauigkeit bestimmt, es dennoch ganz im Allgemeinen hält, den Gesetzen und Gesinnungen der feinen Gesellschaft gemäß, wo sie ihren Ursprung und ihre Heimat hat." 
But what is meant here by an innate tendency to irony? Surely not romantische Ironie, the ironic superiority of the poet over the characters of his creation. This would predicate a very much more aggressive subjectivity than that which Schlegel has been so careful to restrict and limit: a subjectivity which manifests itself only in the author's choice of subject. Nor should it be forgotten that Schlegel has the Decamerone constantly in mind. Even a thorough going Romanticist would have hesitated to charge Boccaccio with "Romantic Irony" and thereby put himself in an absurdly indefensible position. $\mathrm{Haym}^{1}$ ) has shown how varied and contradictory Fr. Schlegel's conceptions of "irony" were at different periods of his life, but as it happens, one of the earliest and clearest of these definitions throws a great deal of light on this particular feature of the essay on Boccaccio. The definition of 1797 runs: „Ironie ist die Form des Paradoxen. Paradox ist alles, was zugleich groß und gut ist" ${ }^{\text {"2). }}$. Three years later in the last pages of the Athenaeum he returns to this definition when attempting to clear up many misunderstandings, particulary that of the term "irony" 3 ), - and in the following year the Boccaccio essay was written. It is then not only entirely possible, but even most probable, that Schlegel here uses Ironie and paradox interchangeably. Certainly the novelle from Boccaccio to the present day has an innate tendency to paradox or extreme contrast, and this is a point which A. W. Schlegel later elaborated in his conception of the turning points (wendepunkte) which was to form the very core of Tieck's theory of the novelle $e^{4}$.

In this first serious discussion of the novelle two good technical points are made: novelty in theme and a tendency toward paradox or contrast. There is no attempt to distinguish

1) Rud. Haym, Die romantische Schule, Berlin 1870, p. 257 ff., 262, 493. 691; 3. Aufl., 1914, p. 295 ff., 55 I, 753 f.

$\left.{ }^{2}\right)$ Cf. 1. Kritische Fragmente in the Lyceum der schönen Künste, Berlin 1797, Bd. I, Teil 2, I46. 2. A. W. und Fr. Schlegel, Charakteristiken und Kritiken, Königsberg 1801, I, 255. 3. Minor, Fr. Schlegel, II, 190, Nr. 48.

3) Athenaeum, Berlin 1798-1800, III, 345. Cf. Minor, op. cit. II, 39 I.

4) See below, pp. 17, 20, $34 \mathrm{f}$. 
between roman and novelle; both forms exist for Friedrich Schlegel only in so far as they can be made vehicles for the subjectivity of the poet. This is the one really clear and definite statement in his Brief über den Roman ${ }^{1}$ ) which appeared a year before the essay on Boccaccio. For him the novel is ",nicht sowohl eine Gattung, wie ein Element der Poesie“"2) and he loathes the novel ,insofern er eine besondere Gattung sein will“. For him ,ein Roman ist ein romantisches Buch" and he can not conceive of it otherwise than as ,gemischt aus Erzählung, Gesang und andern Formen". As a literary form it differs from the drama in that it is meant to be read, not heard. It does not even yield to the general classification, epic: ,Mein eigentlicher Einwurf ist folgender: Es ist dem epischen Stil nichts entgegengesetzter, als wenn die Einflüsse der eigenen Stimmung im geringsten sichtbar werden; geschweige denn, daß er sich seinem Humor so überlassen, so mit ihm spielen dürfte, wie es in den vortrefflichsten Romanen geschieht. "3) Quite as in the case of the novelle he is convinced „daß das Beste in den besten Romanen nichts anderes ist, als ein mehr oder minder verhülltes Selbstbekenntnis des Verfassers" 4 ), and we are not surprised when he concludes: „Die Confessions von Rousseau sind in meinen Augen ein höchst vortrefflicher Roman; die Heloise nur ein sehr mittelmäßiger"5).

Schleiermacher's Vertraute Briefe über Fr. Schlegels Lucinde ${ }^{6}$ ) show conclusively that his conception of the technical aspect of roman and novelle was at least equally confused. He states explicitely that Wilhelm. Meister is nothing but a novelle, while Lucinde on the contrary is a real novel ${ }^{7}$ ). At first even the best critical brain of the movement, A. W. Schlegel, was sufficiently biased to give a definition of the novel that would better suit the märchen of early Romanticism: „Um es kurz zu

1) Athenaeum, III (1800), I12-I28; Sämtliche Werke (1825-46), Bd. V; J. Minor, op. cit., II, $367-76$, here cited.

2) Minor, 373 .

3) loc. cit. 373 .

4) loc. cit. 374 .

$\left.{ }^{5}\right)$ loc. cit 375 .

9) Lübeck und Leipzig 1800, Anfang des 9. Briefes.

7) Cf. Haym, op. cit. 522; 3. Aufl., $58 \mathrm{r}$. 
sagen, im echten Roman ist entweder alles Episode oder gar nichts, und es kommt bloß darauf an, daß die Reihe der Erscheinungen in ihrem gaukelnden Wechsel harmonisch sei, die Phantasie festhalte und nie bis zum Ende die Bezauberung sich auflösen lasse "1). Later his brother's Lucinde became for him an „Unroman“"2), and in the Berlin Lectures ${ }^{3}$ ), delivered.in the years I8oI-04, he has come to considerable clarity in his ideas on this and other literary forms. Here ${ }^{4}$ ) he points out that, in contrast with classic antiquity, prose is an element met with in the first beginnings of modern literature. Prose is the natural and essential medium of the novel, which is not a late and degenerate form in modern European literature, but one that is representative of the best which the period produced. In classical antiquity history approached the epic so closely in treatment that Herodotus is without question to be ranked among the poets. In modern literature poetry stands so closely in touch with history that Dante, Shakespeare and Camoens rank among the best of national historians. Our daily life however is full of remarkable occurrences which find place neither in political history as such nor in poetry with historic background, and these events, at once typical and yet out of the ordinary, are worthy of being recorded in some fashion: ,Deswegen muß es auch in der modernen Poesie eine eigentümlich historische Gattung geben, deren Verdienst darin besteht, etwas zu erzählen, was in der eigentlichen Historie keinen Platz findet, und dennoch allgemein interessant ist. Der Gegenstand der Historie ist das fortschreitende Wirken des Menschengeschlechts; der jener wird also dasjenige sein, was immerfort geschieht, der tägliche Weltlauf, aber freilich damit er verdiene aufgezeichnet zu werden. Die Gattung, welche sich dies vornimmt, ist die Novelle, und hieraus läßt sich einsehen, daß sie, um echt

1) A. W. Schlegel, Sämtliche Werke hrsg. von Ed. Böcking, Leipzig I846-47, XI, 408-26: a review of Cervantes' Don Quixote in Tieck's translation, first published in the Jenaische Zeitung, I799, Nrs. 230-3I.

$\left.{ }^{2}\right)$ Cf. Haym, op. cit. 835 ; 3. Aufl., 553.

a) A. W. Schlegel, Vorlesungen über schöne Literatur und Kunst, nach der Hs. hrsg. von J. Minor, 3 Bde., Heilbronn I884. (Seufferts Literaturdenkmale, Bd. XVII, XVIII, XIX.)

๑) op. cit., XIX, $240 \mathrm{ff}$. 
zu sein, von der einen Seite durch seltsame Einzigkeit auffallen, von der anderen Seite eine gewisse allgemeine Gültigkeit haben $\mathrm{mu} B$, wie man denn leicht bemerken kann, daß viele der besten und wahrhaft unsterbliche Geschichten in allen Ländern und Zeiten erzählt werden, als gerade dort und dann geschehen, worin man auch in einem gewissen Sinne unstreitig recht hat. Da nun die Novelle Erfahrung von wirklich geschehenen Dingen mitteilen soll, so ist die ihr ursprünglich und wesentlich eigene Form die Prosa' ${ }^{\text {(1) }}$ ). More precisely stated: „Die Novelle ist eine Geschichte außer der Geschichte; sie erzählt folglich merkwürdige Begebenheiten, die gleichsam hinter dem Rücken der bürgerlichen Verfassungen und Anordnungen vorgefallen sind“' ${ }^{\text {) }}$.

Since both roman and novelle deal with actuality and prose is therefore their essential medium, it follows that verse is here distinctly out of place. Verse is a fitting medium for the medieval romances of chivalry, since they do not attempt to portray actual occurrences, but move in a world of fantasy. This is not the case with the novelle, and the use of verse by Hans Sachs, La Fontaine and Wieland is ,eine leere und verkehrte Tendenz. " ${ }^{\text {) }}$ ) The French fabliaux took the verse form with no conscious artistic purpose, doubtless only as an aid to the memory and to facilitate oral transmission, but Boccaccio, the conscious artist, in reworking the same material, chose with unerring instinct the prose form. La Fontaine, on the other hand, thinking to improve upon Boccaccio, failed of his effect in every instance and chiefly through the use of verse, the unsuitable medium. „Seine Erzählungen rücken nicht aus der Stelle, und die wesentlichen Punkte verschwimmen ganz in der fremdartigen übergegossenen Brühe" ${ }^{\text {". }}$ ) Wieland's novellen in verse are likewise ,das non plus ultra von laxer Weitschweifigkeit" ${ }^{\text {"5) }}$. Only as a part of a larger whole is the novelle at all justified in assuming the verse form. Ariosto is not bound by the restrictions which Wieland and La Fontaine disregard to their detriment: ,Unstreitig hatte er dabei den
1) loc. cit. 242 .
2) loc. cit. 248 .
$\left.{ }^{3}\right)$ loc. cit. 243 .
4) loc. cit. 243 .
s) loc. cit. 244 . 
Boccaz als das große Muster beständig vor Augen, daher die rasche Bewegung, Leichtigkeit, Konzision seiner Erzählungen, das Verzichtleisten auf unpassenden Schmuck, welches man ihm dann und wann als Trockenheit vorgeworfen"1).

Versification of good novelle material is to be condemned, since it tends to retard the action and militates against the necessary concentration, but this is not true of dramatization. Both novelle and drama are dependent for their effect upon the elimination of all elements not essential to the rapid forward movement of the plot: „Es kann das Drama dadurch einen eigenen geheimnisvollen Reiz gewinnen, daß der Dichter seine Erfindung begrenzt und eine bedingte Aufgabe sich zur Lösung vorsetzt. Möglich mag es vielleicht sein, alle Novellen zu dramatisieren, und dies könnte vielleicht, bei der Notwendigkeit im Dramatischen gründlicher und detaillierter zu motivieren, eine Probe der Richtigkeit abgeben. Keinesweges aber möchte ich behaupten, daß jede Novelle die bequeme Empfänglichkeit für die dramatische Form sogleich solle ansehen lassen; denn es könnten zufällige Äußerlichkeiten im Wege stehen. So viel ist gewiß: die Novelle bedarf entscheidender Wendepunkte, so daß die Hauptmassen der Geschichte deutlich in die Augen fallen, und dies Bedürfnis hat auch das Drama. Mit leisen und allmählichen Fortschritten und Veränderungen $b l o B$ in den inneren Verhältnissen der Personen zu einander ist es nicht getan, diese bleiben der ausführlichen Darstellung des Romans billig vorbehalten, denn sie fordern eine graduelle Entwicklung“').

Though the drama and the novelle are so closely related that capability of dramatization might be made a test for the worth of the material treated in a given novelle, it by no means follows that the novel, so long held to differ from the novelle chiefly in bulk alone, will yield to this same test. „Aus obigem ergibt sich schon, daß nicht gefordert werden kann, jeder Roman solle auch als Novelle verkürzt gedacht werden dürfen. Allein das ist ausgemacht, $\mathrm{da} B$ viele der modernen und unromantischen Romane sich gerade dasselbe zum Ziel gesetzt, was die

1) loc. cit. 244 .

2) loc. cit. 245 . 
Novelle: nämlich Erfahrungen über den Weltlauf mitzuteilen, und etwas als wirklich geschehen $z u$ erzählen .... Wie wenige dies leisten, liegt wieder am Tage. Denn erstens enthalten sie keine Wahrheit, sondern Fratzen, und zweitens geschieht auch nichts darin. Im besten Falle aber, wenn beides geleistet wird, wofern das Detail .... . keinen poetischen Wert an sich hat, so muß doch der Gehalt eines solchen Romans auf das eigentlich Faktische reduziert werden, d. h. dasjenige, was sich darin zur Novelle qualifiziert ..... Eben wegen dieser faktischen Leerheit ist es mit der Dramatisierung solcher Romane so übel gegangen, da wir vielmehr unter den aus Novellen entwickelten Dramen die reichhaltigsten Meisterstücke aufzuweisen haben" ${ }^{\prime 1}$ ). In contrast with Romeo and Juliet Goldoni's dramatization of Pamela is cited sardonically as a play ,welches des Romans vollkommen würdig ist" ${ }^{\text {"2). }}$.

Schlegel then proceeds to definite details of technic: „Um eine Novelle gut zu erzählen, muß man das Alltägliche, was in die Geschichte mit eintritt, so kurz als möglich abfertigen, und nicht unternehmen, es auf ungehörige Art aufstutzen zu wollen, nur bei dem Außerordentlichen und Einzigen verweilen, aber auch dieses nicht motivierend zergliedern, sondern es eben positiv hinstellen und Glauben dafür fordern. Das Unwahrscheinlichste darf dabei nicht vermieden werden, vielmehr ist es oft gerade das Wahrste, und also ganz an seiner Stelle. An die materielle Wahrscheinlichkeit, d. h. die Bedingungen der Wirklichkeit eines Vorfalls, muß sich der Erzähler durchaus binden, hier erfordert sein Zweck die größte Genauigkeit“"3). „Die Novelle kann von ernsten Begebenheiten mit tragischer Katastrophe bis zur bloßen Posse alle Töne durchlaufen, aber immer soll sie in der wirklichen Welt zu Hause sein, deswegen liebt sie auch die ganz bestimmten Angaben von Ort, Zeit und Namen der Personen. Daher muß sie den Menschen in der Regel nach seinem Naturstande nehmen, d. h. mit allen den Schwächen, Leidenschaften und selbstischen Trieben, welche der. ungeläuterten Natur anhängen. Sie soll den Weltlauf schildern,
1) loc. cit. 246 .
) loc. cit. 246 .
$.2)$ loc. cit. 247 . 
wie er ist; sie darf also die Motive im allgemeinen nicht über Gebühr veredeln"1).

A comparison of the work of the brothers Schlegel on the theory of the novelle readily brings characteristic differences to light. Friedrich sees in the novelle, strictly in accord with his Romantic program, little else than a suitable vehicle for poetic subjectivity; the clearer critical mind of the elder brother on the contrary is concerned only with establishing, as objectively as may be, the character and limits of a poetic genre. Friedrich, like all who preceed him, fails to distinguish between the novel and the novelle, but he does point out two essentials: novelty of theme and (if our interpretation be correct) a tendency to paradox or extreme contrast. August Wilhelm is not altogether clear in his distinction between the two epic forms, but it is evident that the briefer form is to his thinking by no means simply a condensed novel, and he states definitely that the gradual and leisurely development of character is permissable only in the novel ${ }^{2}$ ). This implies a demand for concentration which is made explicitly in another connection ${ }^{3}$ ). With him also novelty of theme is a dominant note; we meet repeatedly with such expressions as ,,seltsame Einzigkeit“, „,merkwürdige Begebenheiten“, ,,das Außerordentliche

1) loc. cit. 247 f. This passage is reminiscent of Schleiermacher's Vertraute Briefe (9. Brief), where he allows only the novelle "das Gemeine und Unwürdige mit.auf den Schauplatz zu bringen". The idea that the characters of the story should not be idealized out of all human semblance may well be a reminiscence of the frame story to Goethe's Unterhaltungen deutscher Ausgewanderten. See below, p. 24 and note I.

2) Cf. Spielhagen, Beiträge zur Theorie und Technik des Romans, Leipzig 1883 , p. 245 , where the chief distinction between novel and novelle is based upon the criterion of fixed and developing character. He returns again to the same idea in the Neue Beiträge zur Theorie und Technik der Epik und Dramatik, Leipzig I 898, p. 74: ,.... immer wird ihr [der Novelle] Charakter bleiben, da $B$ sie - zum Unterschied von dem Roman, in welchem eine Entwicklung der Charaktere, mindestens des Helden stattfindet - fertige Charaktere aufeinander treffen läßt, die sich in dem Kontakt nur zu entfalten, gewissermaßen auseinanderzuwickeln haben." Mundt regards the matter in the same light (see below, p. $42 \mathrm{f}$. and p. 43 , note I), but for Schlegel it is not nearly so vital a matter: it is one reason for the comparative bulk of the two forms, and little else.

${ }^{3}$ ) See beginning of quotation in next paragraph above. 
und Einzige", and the like. And Friedrich's idea of the tendency to contrast and paradox in the novelle brings August Wilhelm to what is perhaps his most important contribution to the entire discussion, to the idea that the novelle and the drama both require "decisive turning points" (entscheidende Wendepunkte) in their plots and are hence closely related as literary species. If we except the hint given by Lessing for a specific instance, A. W. Schlegel must be credited with having first pointed out the essentially dramatic elements in the structure of the novelle, a feature repeatedly emphasized by modern theorists, especially since Spielhagen $^{1}$ ), who goes farther than Schlegel would venture and makes the possibility of dramatization the supreme test for the value of any novelle motif ${ }^{2}$ ). It is here that Schlegel especially emphasizes the need of concentration: only the unusual and unique may be dwelt upon at any length. He conceives the novelle to be then: the objective relating in prose of events which are extraordinary to the point of uniqueness, and yet in a sense so typical as to be absolutely credible. Noteworthy in this connection are the words: „Das Unwahrscheinlichste darf dabei nicht vermieden werden, vielmehr ist es oft gerade das Wahrste, und also ganz an seiner Stelle". The structure of the novelle is dramatic, not only in its concentration (upon the unusual), but also in its need of decisive turning points in the action. This concentration upon essentials predicates a conciseness which excludes all extraneous matter absolutely, even to the development

1) Cf. Spielhagen, Beiträge, $246 \mathrm{f}$ : „Deshalb hat auch die Novelle sowohl in ihrem Endzweck als in ihrer künstlerischen Okonomie eine entschiedene Ahnlichkeit mit dem Drama, während der Roman (und nichts ist vielleicht bezeichnender für den tiefen Unterschied zwischen Novelle und Roman) in jeder Beziehung des Stoffes, der Okonomie, der Mittel ..... der volle Gegensatz des Dramas ist." Th. Storm's feeling toward the relation of the novelle to the drama was similar: „Die Novelle ist die strengste und geschlossenste Form der Prosadichtung, die Schwester des Dramas." Storm an Keller, 14. August I88r. Cf. Briefwechsel zwischen Th. Storm und G. Keller, hrsg. von Albert Köster, Berlin I904, p. II6. Cf. also II9 f.

2) Beiträge, 285: ,Kein Romanstoff ist auch zugleich ein Dramenstoff, folglich kann kein Roman in ein Drama umgedichtet werden. Ein Novellenstoff ist fast immer zugleich dramatisch, folglich kann beinahe jede Novelle in ein Drama umgedichtet werden." 
of character, and which will result in relative brevity. As to the style, August Wilhelm agrees with his brother that the manner of the cultivated raconteur is the ideal for the novelle: „Die Erfahrungen des geselligen Lebens sind eine der beliebtesten und angemessensten Unterhaltungen in der Gesellschaft; deswegen ist das eigentliche Muster für den Vortrag der Novelle der gebildete gesellige Erzähler, natürlich mit derjenigen Freiheit der Erhöhung des natürlichen Urbildes, welche der Poesie überall zugestanden wird $\left.^{\prime \prime 1}\right)$. Not only the persons who appear in the frame story of the Decamerone, but also the Abbe in Goethe's Unterhaltungen deutscher Ausgewanderten may well have furnished Schlegel with a model for „der gebildete gesellige Erzähler" of this paragraph.

In the same year with the close of A. W. Schlegel's Berlin Lectures (1804) appeared Sophie Brentano's Spanische Novellen, a translation and adaption of the Novelas amorosas y exemplares of Donna Maria de Zayas y Sottomayor. In reviewing this translation an anonymous critic makes an interesting attempt to define in a single sentence the form as cultivated in 17 th century Spain: ,,Schon die Einleitung beweist, daß die Verfasserin es klar gedacht hat, daß die Novelle eine Erzählung sein solle, welche auf eine romantische, gesellschaftlich interessierende und beziehungsreiche Weise die Aufmerksamkeit und die Neugier stimmen, spannen, befriedigen soll. “2) The definition is of course unsatisfactory because of its failure to set off the novelle from such other related forms as the erzählung, or even the novel, but it is interesting for its echo of the Schlegels' insistence upon the high social origin of the novelle as a distinguishing characteristic.

A reflection of some of the best points already made by A. W. Schlegel is found in the foreword to Wieland's Novelle ohne Titel (1805) where one of the characters of the frame story

1) Seufferts Literaturdenkmale, XIX, 247.

$\left.{ }^{2}\right)$ Jenaische Allg. Literatur-Zeitung, I 804, Nr. I94, Sp. 300 ff. Cited in Clemens Brentanos Sämtl. Werke hrsg. von Carl Schüddekopf u. A., München and Leipzig rgII, XIII, p. XX. 
is made to distinguish between fairy tale and novelle as follows: „Bei einer Novelle, sagte er, werde vorausgesetzt, daß sie sich weder im Dschinnistan der Perser, ..... noch in einem andern idealischen oder utopischen Lande, sondern in unserer wirklichen Welt begeben habe, wo alles natürlich und begreiflich zugeht, und die Begebenheiten zwar nicht alltäglich sind, aber sich doch unter denselben Umständen alle Tage allenthalben zutragen könnten “1). This is exactly Schlegel's conception: actuality which is unusual, yet of typical occurrence and hence credible. Naturally Wieland's tastes did not lie in the direction of a form so rigorous in its demands upon the poet, and the character acting as his mouthpiece immediately resumes: „Es sei also nicht von einer Novelle zu erwarten, daß sie (wenn auch alles übrige gleich wäre) den Zuhörern eben denselben Grad von Anmutung und Vergnügen gewähren könnte, den man aus glücklich gefundenen oder sinnreich erfundenen und lebhaft erzählten Märchen zu schöpfen pflege." As Heyse has pointed out ${ }^{2}$ ), Wieland shows here small sense for the artistic development of a good novelle motif, for with monstrous naiveté he gives his readers a choice between different conclusions of the story. Spielhagen would have condemned such lack of literary artistry even more caustically, for he declares in no uncertain terms that the conclusion of any novelle is predicated absolutely by the nature of the characters which come into conflict during the course of the story. ${ }^{3}$ ) In English criticism we have an interesting parallel to Spielhagen's view of this matter when Robert Louis Stevenson writes: "To make another end, that is to make the beginning all wrong. The dénouement of a long story is nothing, it is just a full close, which you may approach and ac-

1) Wieland, Werke (Hempel-Ausg.), XIII, 78.

2) Deutscher Novellenschatz, I, p. VI f. Cf. Wieland, op. cit. 93 ff.

3) Beiträge, 245: „Die Novelle hat es mit fertigen Charakteren zu tun, die, durch eine besondere Verkettung der Umstände und Verhältnisse, in einen interessanten Konflikt gebracht werden, wodurch sie gezwungen sind, sich in ihrer allereigensten Natur zu offenbaren, also, daß der Konflikt, der sonst Gott weiß wie hätte verlaufen können, gerade diesen, durch die Eigentümlichkeit der engagierten Charaktere bedingten und schlechterdings keinen anderen Ausgang nehmen kann und muß". 
company as you please - it is a coda, not an essential member of the rythm; but the body and end of a short-story is bone of the bone and blood of the blood of the beginning"'1).

After the work of the Schlegels the first really important contribution to the theory of the novelle is Goethe's famous definition in r827: ,Was ist die Novelle anders als eine sich ereignete, unerhörte Begebenheit ?" "2) Here, as elsewhere so often, Goethe has happily expressed in the briefest possible formula the result of a long investigation, one which can be traced definitely as far back as the year I795, thus antedating in a fashion even the pioneer work of the Schlegels. It is intensely interesting to trace the growth of this conception in the mind of the poet and, incidentally, to arrive at the real meaning of the definition; for as it stands alone in its epigrammatic brevity the expressions ,,unerhört", ,,sich ereignet" and ,Begebenheit" are all open to an interpretation which would distort the meaning that Goethe intended them to convey $\left.{ }^{3}\right)$.

To follow Goethe's definition to its source we must go back to his Unterhaltungen deutscher Ausgewanderten (I795). Here within the frame story, which is a modern adaptation of Boccaccio's frame for the Decamerone, there are six stories of varied length and character, two of them real novellen: Ferdinand and the Prokurator. The former was entirely Goethe's own creation, while the latter has a French source in the Cent nowvelles nouvelles, though Schiller ascribed it to Boccaccio ${ }^{4}$ ). Throughout the entire frame story the word novelle is nowhere so much as mentioned, though the "moral tale" and the fairy tale are defined at some length. More important is the definition of the term erzählung. The Baroness, a character of the frame story, voices the views of

1) Valima Letters, I, 47. Quoted by Brander Matthews, op. cit., I 5 f.

$\left.{ }^{2}\right)$ Gespräche mit Eckermann, 29. Jan. I 827.

3) Paul Joh. Arnold in his article on Goethes Novellenbegriff, Lit. Echo, $\mathrm{XIV}$ (I9II-I2), Sp. I25I-54, has given an excellent interpretation of the definition, but with no attempt to trace the growth of the conception chronologically.

4) Schiller an Goethe, 28. Okt. I794 und 20. März 1795. Cf. Schillers Briefe, Kritische Gesamtausgabe, hrsg. von Fritz Jonas, Stuttgart usw. I 892 ff., IV, 49 f., I 50. 
the author, and much of what she says applies as well to the novelle, though no distinction between the two forms is drawn: „Doch wenn Sie uns eine Geschichte zur Probe geben wollen, so muß ich Ihnen sagen, welche Art ich nicht liebe. Jene Erzählungen machen mir keine Freude, bei welchen, nach Weise der Tausend und Einen Nacht, eine Begebenheit in die andere eingeschachtelt, ein Interesse durch das andere verdrängt wird; wo sich der Erzähler genötigt sieht, die Neugierde, die er auf eine leichtsinnige Weise erregt hat, durch Unterbrechung zu reizen, und die Aufmerksamkeit, anstatt sie durch eine vernünftige Folge zu befriedigen, nur durch seltsame und keineswegs lobenswürdige Kunstgriffe aufzuspannen. Ich tadle das Bestreben, aus Geschichten, die sich der E inheit des Gedichts nähern sollen, rhapsodische Rätsel zu machen und den Geschmack immer tiefer zu verderben. Die Gegenstände Ihrer Erzählungen gebe ich Ihnen ganz frei, aber lassen Sie uns wenigstens an der Form sehen, daß wir in guter Gesellschaft sind. Geben Sie uns zum Anfang eine Geschichte von wenig Personen und Begebenheiten, die gut erfunden und gedacht ist, wahr, natürlich und nicht gemein, so viel Handlung als unentbehrlich und so viel Gesinnung als nötig; die nicht still steht, sich nicht auf Einem Flecke zu langsam bewegt, sich aber auch nicht übereilt; in der die Menschen erscheinen wie man sie gern mag, nicht vollkommen, aber gut, nicht außerordentlich, aber interessant und liebenswürdig. Ihre Geschichte sei unterhaltend, so lange wir sie hören, befriedigend, wenn sie zu Ende ist, und hinterlasse uns einen stillen Reiz weiter nachzudenken“1).

Noteworthy in this passage is the expression „Geschichten, die sich der Einheit des Gedichts nähern sollen". Half a century later Edgar Allan Poe was to express precisely this idea in his definition of the short-story. The idea that we must see from the very form of the story "that we are in good society" expresses in its way the distinction later drawn by the Schlegels between the higher social origin of the novelle and the more vulgar source of the schwank and fabliau. It can hardly be asserted that Goethe has here the novelle as a distinct species definitely

1) Goethe, Werke, Weimarer Ausgabe, XVIII, $158 \mathrm{f}$. The spacing throughout does not appear in the original. 
in mind, and yet it is significant that the four preceeding stories are nothing more than anecdotes, while the two that follow are the only real novellen of the group. At the close of the Prokurator the Baroness remarks: „..... er [der Prokurator] ist zierlich, vernünftig, unterhaltend und unterrichtend; so sollen alle diejenigen sein, die uns von einer Verirrung abhalten oder davon zurückbringen wollen. Wirklich verdient die Erzählung vor vielen anderen den Ehrentitel einer moralischen Erzählung “1). She sees indeed only the moral import of the story, and she makes no comment on the form, which is, however, entirely in agreement with the demands of her own definition, including the high level of culture and the "unity which approaches that of the poem".

Before the beginning of the Ferdinand-Novelle another person of the frame story gives the conversation a new turn, and what is said here makes the introduction to Wieland's Novelle ohne Titel, which appeared ten years later, sound decidedly reminiscent: „Ich leugne nicht, daß ich die Geschichten nicht liebe, die unsere Einbildungskraft immer in fremde Länder nötigen. $\mathrm{Mu} B$ denn alles in Italien und Sizilien, im Orient geschehen? Sind denn Neapel, Palermo und Smyrna die einzigen Orte, wo etwas Interessantes vorgehen kann? Mag man doch den Schauplatz der Feenmärchen nach Samarcand und Ormus versetzen, um unsere Einbildungskraft zu verwirren. Wenn Sie aber unsern Geist, unser Herz bilden wollen, so geben Sie uns einheimische, geben Sie uns Familiengemälde, und wir werden uns desto eher darin erkennen, und wenn wir uns getroffen fühlen, desto gerührter an unser Herz schlagen" 2 ). One has only to glance through any one of the fourteen volumes of A. G. Meißner's Skizzen (r778-96) to learn to what depths the so-called familiengemalde of that day had sunk. In his Prokurator Goethe had just given an example of what the much abused "moral tale" might become in the hands of a master, and he proceeds in Ferdinand to do as much for the familiengemälde. Lack of psychological penetration was perhaps the greatest fault of this type of story, and so the narrator is made to approach the problem from pre-

\footnotetext{
1) loc. cit. $187 \mathrm{f}$.

2) loc. cit. $190 \mathrm{f}$.
} 
cisely the psychological side when he replies: „Auch darin soll Ihnen gewillfahrt werden. Doch ist es mit den Familiengemälden eine eigene Sache. Sie sehen einander alle so gleich, und wir haben fast allc Verhältnisse derselben schon gut bearbeitet auf unsern Theatern gesehen. Indessen will ich's wagen und eine Geschichte erzählen, . . . . die nur durch eine genaue Darstellung dessen, was in den Gemütern vorging, $n$ e $u$ und in teressa $n t$ werden dürfte"1).

If not in theme, then at least in treatment, the story is to be "new and interesting", and this has ever been a prime requirement for the novelle. In two brief paragraphs the narrator begins his story with a concise statement as to the hero's inherited traits of character, then interrupts the course of the story for a moment to make a statement which, in the light of the definition of 1827 , is highly significant: „Ich übergehe mancherlei Scenen, die in seiner Jugend vorfielen, und erzähle nur eine $B$ e g e be $n$ heit, die seinen ganzen Charakterins Lichtsetzt, und in seinem Leben eine entschiedene Epoche $\left.\mathrm{macht} \mathrm{e}^{\prime \prime 2}\right)$. The entire novelle consists really of this single "occurrence" which throws a spot-light on the character of the hero and marks an epoch in his life. Some thirty years later Tieck expressed the same idea in very much the same way: ,.... die Novelle [sollte] sich dadurch aus allen anderen Aufgaben hervorheben, daß sie einen großen oder kleinen $\mathrm{V}$ orf a 11 in $\mathrm{s}$ hellst e $\mathrm{Licht}$ stelle ...." $\left.{ }^{\prime 3}\right)$. In this instance Goethe seems to our modern sense almost too anxious to force the „Begebenheit" in question into the lime-light, for just as the reader is about to learn what it is, the narrator is made to say: „Zu dieser Gemütsstimmung traf e in sonderbare r $Z$ ufall, der ihm eine reizende Gelegenheit gab, dasjenige zu tun, wozu er nur einen dunk-

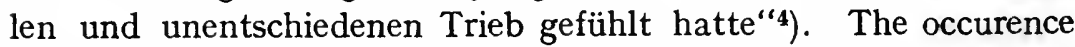
is then related, its consequences are depicted, and we are shown that it did indeed mark an epoch in the life of the hero. At the close of the story one of the hearers remarks: „Diese Geschichte

1) 1oc. cit. I9I.

2) loc. cit. 192.

3) See below, p. 34 .

4) Werke, XVIII, I99. 
gefällt mir,... und ob sie gleich aus dem gemeinen Leben genommen ist, so kommt sie mir doch $\mathrm{nicht}$ all $\mathrm{täglich}$ vor" $\left.{ }^{1}\right)$. This juxtaposition of the expressions ,,aus dem gemeinen Leben" and "nicht alltäglich" is precisely that of ,sich ereignet" and ,unerhört" in the definition of 1827 , and the former furnishes an excellent commentary on the latter. By the addition of the „Begebenheit, die.... in seinem Leben entschiedene Epoche machte" we have the entire definition of thirty years later complete except for the one word "Novelle". Evidently the poet realizes that he is creating here a very definite type of story. His having neglected to give it the name we might expect is immaterial. However even the name can be supplied by reference to Goethe's letter to Schiller of December I7th, I795: ,Dagegen habe ich an den $\mathrm{N}$ ovelle $\mathrm{n}$ des Cervantes einen wahren Schatz gefunden, sowohl der Unterhaltung als der Belehrung. Wie sehr freut man sich, wenn man das anerkannte Gute auch anerkennen kann, und wie sehr wird man auf seinem Wege gefördert, wenn man Arbeiten sieht, die $n a c h$ eben den Grundsätzen gebildet sind, $n$ ach denen wir $n a c h$ unserm Maße und in unserm Kreise selbst verfahren" ${ }^{2}$ ).

There can be no doubt that Goethe is here referring to the novellen of the Unterhaltungen, then only just published, and that he finds in them essentially the same type of story that Cervantes had created in his Novelas exemplares. The Unterialtungen appeared serially in Schiller's Horen between January and October I795, and the various stories within this framework were all written after October I794, as the correspondence with Schiller shows. We have no evidence that Goethe became acquainted with the Novelas exemplares till after the publication of the Unterhaltungen ${ }^{3}$ ). Independent of Cervantes, he took over the Romance novella and proceeded

1) loc. cit. $216 \mathrm{f}$.

2) Werke, Abt. IV, Bd. X, 350 .

$\left.{ }^{3}\right)$ Gervinus assumes that Goethe read the Novelas exemplares for the first time in December 1795: ,Cervantes ...... griff zu dieser Gattung [Novelle] und ist das große Beispiel darin auch für Tieck gewesen, und Goethe durfte sich fühlen, mit ihm, ohne ihn zu kennen, hier auf gleichem Wege gewandelt zu sein." Geschichte der deutschen Dichtung, 5. Aufl., Leipzig 1874, V, 775. 
to broaden and deepen it in its psychological aspect, quite in the spirit of his great predecessor. And so Goethe would appear to have created two true novellen in the modern sense and even to have furnished, between the lines as it were, a definition for the genre, - all this in I795, six years before Fr. Schlegel's essay on Boccaccio and nearly a decade before the close of A. W. Schlegel's Berlin Lectures.

In the following year (I796) the novelle in verse, Alexis und Dora, appeared in the May and June numbers of the Musenalmanach, and here the problem is the same as that of the Ferdinand-Novelle: the depiction of the entire life and character of the hero in the single "Begebenheit“. ${ }^{1}$ ) A year later Goethe planned an epic poem, "Die Jagd", which on Schiller's advice he laid aside for the time being, but reworked thirty years later in prose as the "Novelle", the discussion of which with Eckermann gave rise to the definition of 1827 . The correspondence with Schiller in the months of April and June, 1797, is full of material which throws light on the later definition. On the 22nd of April he writes to Schiller: ,Mein neuer Stoff [,Die Jagd'] hat keinen einzigen retardierenden Moment, es schreitet alles von Anfang bis zu Ende in einer geraden Reihe fort, allein er hat die Eigenschaft, daß große Anstalten gemacht werden, daß man viele Kräfte mit Verstand und Klugheit in Bewegung setzt, daB aber die Entwicklung auf eine Weise ge schieht, die den Anstalten ganz entgegen ist und auf einem ganz unerwarteten, jedoch na$t$ ür liche $n$ W e ge. Nun fragt sich, ob sich ein solcher Plan auch für einen epischen ausgeben könne. . . . . I Ich habe jetzt keine interessantere Betrachtung, als über die Eigenschaften der Stoffe inwiefern sie diese oder jene Behandlung fordern. Ich habe mich darinnen so oft in meinem Leben vergriffen, daB ich endlich einmal ins Klare kommen möchte um wenigstens künftig von diesem Irrtum nicht mehr zu leiden"'2).

Here is an element in the theory of the novelle which the later definition does not touch upon, but of which the Schlegels,

1) Cf. K. Heinemann, Goethe, 3. Aufl., Leipzig 1903, 520 f.

2) Werke, IV. Abt., Bd. XII, 93 f. 
and later Tieck, made much: the element of paradox, the development toward an ending which one is not led to expect from the beginning, - unless, indeed, we see in the word ,unerhört" this element as well as that of novelty of theme. In his reply Schiller seizes at once upon this element as essentially unepic: „Die Art, wie Sie Ihre Handlung entwickeln wollen, scheint mir mehr der Komödie als dem Epos eigen zu sein. Wenigstens werden Sie viel zu tun haben, ihr das Überraschende, Verw underung Erregende zu nehmen, weil dieses nicht so recht episch ist"1). To this Goethe replies: „Wird der Stoff nicht für rein episch erkannt, ob er gleich in $\mathrm{meh} \mathrm{r}$ a ls $\mathrm{E}$ in e $\mathrm{m}$ Sinne bede utend und in teressant ist, so mußsich dartun lassen, in welcher andern Form er eigentlich behandelt werden müBte“2 $)$. Here the matter is allowed to rest for the time being, but in June Goethe informs Schiller that he has thought of recasting the material in a poem with strophic form, and Schiller replies in agreement with the idea: ,Zugleich [in der Strophenform] participiert er alsdann von gewissen Rechten des romantischen Gedichts, ohne daß es eigentlich eines wäre, es darf sich wo nicht des Wunderbaren, doch des Selts a men und Überras che nde n mehr bedienen, und.... erweckt dann gar kein Befremden mehr"'3). To this Goethe replies on the following day: ,..... es scheint mir jetzt auch ausgemacht, da $B$ meine Tiger und Löwen in diese Form gehören, ich fürchte nur fast, daB das eigentliche Interessante des $\mathrm{Su}$ j e $\mathrm{t}$ s sich zuletzt gar in e i n e B a 11 a d e auflösen möchte "4).

The idea was then put aside altogether and was not taken up again till thirty years later, when Goethe entirely recast the material for the prose novelle. The last sentence quoted probably marks the first occurrence of the comparison between the ballad and the novelle, which has since become so common. It seems a little strange that Goethe did not turn to the prose form in the first place, but his preference for epic verse may well be due to the fact that Alexis und Dora had just been so

\footnotetext{
1) Schillers Briefe, V, I8I f.

2) Werke, Abt. IV, Bd. XII, Ioo.

3) Schillers Briefe, V, $206 \mathrm{f}$.

4) Werke, Abt. IV, Bd. XII, I 70.
} 
enthusiastically received by the public, while the Unterhaltungen had met with general and outspoken disapproval. Be that as it may, he turned from the novelle to other forms during the next ten years. We know that in 1805 he read the novellen of Cervantes once again, and that with pleasure ${ }^{1}$ ), and it is not improbable that his return to the novelle was at least in part due to his renewed interest in Cervantes. It was not long after this, as we learn from his Journal, that Goethe was at work upon stories later to be woven into the fabric of the Wanderjahre. One of these passages in the Journal is of particular interest here. Under the 9th of December, r807, we find: „Novellen zu Wilhelm Meisters Wanderjahren “2). This seems to be Goethe's first explicit use of the term novelle for any of his own productions. The various stories of the Wanderjahre began to appear in 1809 , some of them separately in the Taschenbuch für Damen (1809, I8I0, I8I6-I9), some not completely before the final edition of the novel in 1829 , but of those which may be classed as novellen none has the compact structure of the two in the Unterhaltungen. In the Tages- und Jahreshefte for the Summer of 1807 Goethe speaks of being at work upon the stories for the Wanderjahre, and among these he mentions Die Wahlverwandtschaften, which he had at first planned to include with the rest ${ }^{3}$ ). However the story eventually outgrew the first plan and was published separately in I809 with the sub-title "Roman". It is interesting to note that critics since Goethe's day (e. g. Mundt and Spielhagen) have been inclined to classify it rather as a novelle. In the tenth chapter of the second part is the story of Die wunderlichen Nachbarskinder to which Goethe gave the sub-title "Novelle", and this was the first of his works to come before the public with that title. It meets with the requirements of the final definition in every respect, and the immediate framework of the story is in places suggestive of the definition. The narrator is described as a man , den

1) H. Voss an K. W. F. Solger, 8. Feb. 1805: „Nun liest Goethe die Cervantischen Novellen, die ihm Freude machen". Cf. Biedermann, Goethes Gespräche, Gesamtausgabe, 2. Aufl., Leipzig I909, I, 384.

2) Werke, Abt. III, Bd. III, 305.

2) Werke, XXXVI, 28. 
eigentlich auf der Reise nichts mehr interessierte als die s o n d e r$\mathrm{b}$ a re $\mathrm{n}$ Ereig $\mathrm{n}$ is se, welche durch natürliche und künstliche Verhältnisse, durch den Konflikt des Gesetzlichen und des Unge bändigten, des Verstandes und der Vernunft, der Leidenschaft und des Vorurteils hervorgebracht werden ... . "1). We are thus prepared in advance for a story that is unusual and paradoxical ${ }^{2}$ ). A few lines below we are given an implicit definition of the term ,,bedeutend“" ,,denn nicht allein bedeutende Bemerkungen, sondern auch die trivialsten Außerungen können auf eine so mißklingende Weise mit dem Interesse der Gegenwärtigen zusammentreffen." And then the narrator is asked to give the company ,etwas von den vielen angenehmen und bedeutenden Anekdoten und Geschichten" which he had made a point of collecting on his travels. Finally as the immediate introduction to the novelle: „Denn nachdem der Begleiter durch manche s onderbare, bede ut e nde, heitere, rührende, furchtbare $\mathrm{Ges} \mathrm{ch}$ i $\mathrm{ch}$ t e $\mathrm{n}$ die Aufmerksamkeit erregt und die Teilnahme aufs höchste gespannt hatte, so dachte er $\mathrm{mit}$ einer $\mathrm{z}$ war sonderbare $n$, aber sanfteren Begebe $n$ heit zu schließen....."

This is the same conception of the novelle that Goethe had held in I795, except for the addition of the idea of paradox which goes back to the correspondence of I797. This receives here considerable prominence, and the conception had undergone no change when in October, I826, Goethe returned to the material of the Jagd and made of it his Novelle. The first notes in the Journal are interesting: (Oct. 4th) „Erneuertes Schema der w u n d e r b a r e n J a g d“ and (Oct. Ioth) „Kleines Gedicht zum Abschluß der projectierten $\mathrm{N}$ ove $11 \mathrm{e}^{\text {("3 }}$ ). From this time on the work is called simply , die Novelle“. In the meantime the original plan for the Jagd had been lost - fortunately, as Goethe himself thought, when he gave Eckermann the completed manuscript

1) Werke, $\mathrm{XX}, 32 \mathrm{If}$.

2) In the body of the novelle itself this idea of paradox is kept constantly in the foreground by such expressions as „Neigung unter der Form des Widerstrebens" or ,, auf eine ganz natürliche aber doch sonderbare Weise stand er seiner schönen Nachbarin abermals entgegen", etc.

2) Werke, Abt. III, Bd. X, 252, 255. 
to $\left.\operatorname{read}^{\mathbf{1}}\right)$. A few days later Goethe explained the construction of the novelle to Eckermann as follows: „Um für den Gang dieser Novelle ein Gleichnis zu haben, ..... . so denken Sie sich aus der Wurzel hervorschießend ein grünes Gewächs, das eine Weile aus einem starken Stengel kräftige grüne Blätter nach den Seiten austreibt und zuletzt mit einer Blume endet. D i e B l u m e war unerwartet, überraschend, abersie $m u$ te k o m m e $n$; ja, das grüne Blätterwerk war nur für sie da .... Zu zeigen, wie das Unbändige, Unüberwindliche oft besser durch Liebe und Frömmigkeit als d u rch Gewalt bezw ungen werde, war die Aufgabe dieser Novelle ..... Dies ist das Ideelle, dies die Blume. Und das

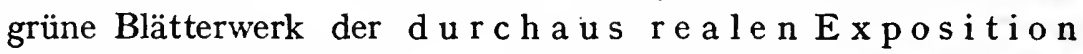
ist nur dieserwegen $\mathrm{da} . .$. . Schiller war gegen eine Behandlung. meines Gegenstandes in Hexametern, wie ich es damals gleich nach Hermann und Dorothea willens war; er riet zu den achtzeiligen Stanzen. Sie sehen aber wohl, daß ich mit der P r o s a am besten gefahren bin. Denn es kam sehr auf ge n a u e $\mathrm{Z}$ e i c h nung der Lokalität an, wobei man doch in solchen Reimen wäre geniert gewesen. Und dann ließ sich auch $\mathrm{der}$ anfänglich ganz reale und am Schluss ganz ideelle Charakter der Novelle in Prosa am besten geben“2).

Here is still the original idea of novelty and surprise combined with the later conception of paradox and contrast, - all within the realm of reality. New is the thought that prose is the proper medium for the realistic, but in this particular A. W. Schlegel was Goethe's predecessor by over a quarter of a century. As in the case of Die wunderlichen Nachbarskinder, Goethe had consciously constructed what he conceived to be a novelle, but he was rather at a loss for a name to give the story. On the evening of January 29th, I827, Eckermann returned the manuscript. No name could be found which suited both the beginning and the end of the story, and so Goethe finally decided

1) Gespräche mit Eckermann, 15. Jan. 1827. Cf. Biedermann, op. cit. III, 317 .

2) loc. cit. $325 \mathrm{f}$. 
to give it the name of the species and let it stand as an "exemplary" novelle in the formal sense of the term, a proceeding which has an earlier parallel in the Märchen of the Unterhaltungen. ,Wissen Sie was, sagte Goethe, wir wollen es die Novelle nennen; denn was ist die Novelle anders als eine sich ereignete unerhörte Begebenheit. Dies ist der eigentliche Begriff, und so vieles, was in Deutschland unter dem Titel Novelle geht, ist gar keine Novelle, sondern bloß Erzählung oder was Sie sonst wollen. In jenem ursprünglichen Sinne einer unerhörten Begebenheit kommt auch die Novelle in den Wahlverwandtschaften vor" ${ }^{1}$ ).

The full import of this final definition becomes clear only through tracing the development of Goethe's conception of the novelle during a period of over thirty years, but even so one can hardly join wholeheartedly in Bastier's boundless enthusiasm. for Goethe's epigram when he declares: "Ces quelques mots contiennent les questions essentielles que peut soulever la Nouvelle techniques, esthétiques, ou éthiques. Il suffit de développer les idées qu'ils enferment: thème unique; unité d'intérêt; singularité et vérité de l'action; aspect historique, périmé de cette action; et enfin, sousentendu: récit de cette action" 2). For him the theory of the novelle begins and ends with Goethe, and he sees in the work of every other theorist purely a dogmatic interpretation pro domo. Nevertheless Goethe's definition, excellent as it is, by no means entirely exhausts the question $\left.{ }^{3}\right)$. Only two years later Tieck was to make a new and very fruitful contribution to the discussion.

Since r82I Tiecks Novellen had been appearing, and in I829, while preparing a collected edition of his works for publication, he feels called upon in a dedicatory preface to define what he conceives to be the novelle as distinguished from all other forms of the prose tale $\left.{ }^{4}\right)$. He deprecates the loose use of the term in Germany to cover any sort of prose tale not included under the rubric roman, and complains that the English have always

1) loc. cit. 335 .

2) Bastier, op. cit. $4 \mathrm{I}$ f. Cf. $40 \mathrm{ff}$.

3) For fuller treatment of this topic cf. my article, Goethe's Theory of the Novelle, Publ. of the Mod. Lang. Association of America, June 1915.

4) Tieck, Schriften, 20 Bde., Berlin 1828-40, XI (1829), pp. LXXXIV-XC. 
styled even their novels novellen ${ }^{1}$ ). In origin the word is Italian and at first it signified ,,jede Erzählung, jeden Vorfall ..... , die neu. nicht bekannt waren“ "2). „Boccaz, Cervantes und Goethe sind die Muster in dieser Gattung geblieben, und wir sollten billig nach den Vorbildern, die in dieser Art für vollendet gelten können, das Wort Novelle nicht mit Begebenheit, Geschichte, Erzählung, Vorfall, oder gar Anekdote als gleichbedeutend brauchen" 3). „Eine Begebenheit sollte anders vorgetragen werden, als eine Erzählung; diese sich von Geschichte unterscheiden, und die Novelle nach jenen Mustern sich dadurch aus allen anderen Aufgaben hervorheben, daß sie einen großen oder kleinern Vorfall ins hellste Licht stelle, der, so leicht er sich ereignen kann, doch wunderbar, vielleicht einzig ist. Diese Wendung der Geschichte, dieser Punkt, von welchem aus sie sich unerwartet völlig umkehrt, und doch natürlich, dem Charakter und den Umständen angemessen, die Folge entwickelt, wird sich der Phantasie des Lesers umso fester einprägen, als die Sache, selbst im Wunderbaren, unter andern Umständen wieder alltäglich sein könnte" ${ }^{4}$ ).

Tieck like his predecessors builds up his theory about the central idea that the theme is to be unusual. This central theme is to be thrown into high relief by the turning point, which brings the story to an unexpected, though, under the given circumstances, perfectly natural conclusion. In a sense this is a repetition of $\mathbf{A}$. W. Schlegel's thought: „Die Novelle bedarf entscheidender Wendepunkte, so daß die Hauptmassen der Geschichte deutlich in die Augen fallen," but the use of the singular and the plural in each case is significant, as is also the fact that the "turning points" are for Schlegel a purely technical criterion serving to associate the novelle with the drama and to distinguish them both from the

1) The reproach would apply rather to the German translators of the socalled Waverley Novellen. There can be no doubt that these German translations of the English name by a cognate term actually did cause considerable confusion. More than twenty years later Reinbeck still had occasion to grow sarcastic over a case where a novel had been given the sub-title Romanze after the analogy with English romance. See below, $p 67$.

2) Schriften, XI, p. LXXXIV.

2) loc. cit. LXXXV.

4) loc. cit. LXXXVI. 
novel, while for Tieck the conception is far more fundamental. Not only is the wendepunkt a technical device for setting the novelle as a genre apart, it also has the greatest significance for the content of each separate story and serves to set the one novelle off against every other in the memory of the reader. Upon it depends not only the characteristic feature of the species, but also the very individuality of each separate specimen. And in this wendepunkt lies Tieck's entire conception of the marvellous, which divides him in this later period so sharply from the Romanticists, with whom he had earlier been closely associated. They had been forced to turn to the past for the wonderful and the marvellous; he believes that the marvellous is never lacking in any age: ,Das Wunder war nicht vor unserer Zeit, es ist zu allen Zeiten. Es ist kein außerordentlicher Zustand, es umgibt uns an allen Orten; es ist in uns, außer uns, unser ganzes Dasein ist ein Wunder" 1).

A. W. Schlegel with the Romanticists had found the present scarcely worthy of poetic treatment, at any rate so far as the novelle is concerned. He asserts: „In der Novelle muB etwas geschehen; ein dreister energischer Charakter der Sitten ist ihr daher vorteilhaft und es läßt sich mehr als bezweifeln, ob es in unsern Zeiten, wo das Leben sich in lauter Kleinlichkeiten zerbröckelt, und fast niemand eigentlich das Herz hat unbekümmert nach seinem Sinne zu leben, möglich sein dürfte, eine solche Masse von Novellen aufzubringen, die in unsern Sitten gegründet und der Denkart des Zeitalters angemessen wären, als die unter den Boccazischen sind, welche einen historischen Grund haben und das damalige Zeitalter schildern" ${ }^{2}$ ). In contrast with Schlegel Tieck is intensely modern in his attitude toward the world about him: „Aber alle Stände, alle Verhältnisse der neuen Zeit, ihre Bedingungen und Eigentümlichkeiten sind dem klaren, dichterischen Auge gewiß nicht minder zur Poesie und edlen Darstellung geeignet, als es dem Cervantes seine Zeit und Umgebung war, und es ist wohl nur Verwöhnung einiger vorzüglichen Kritiker,

1) Rud. Köpke, Ludwig Tieck. Erinnerungen aus dem Leben des Dichters nach mündlichen und schriftlichen Mitteilungen, 2 Bde., Leipzig I855, II, 25 I.

$\left.{ }^{2}\right)$ Seufferts Literaturdenkmale, XIX, 245. 
in der Zeit selbst einen unbedingten Gegensatz vom Poetischen und Unpoetischen anzunehmen"1).

On the technical side, Tieck's discussion of the novelle, as compared with A. W. Schlegel's careful detail work, is sketchy and impressionistic. Given the one clear and decisive element, the turning point, the novelle may proceed in its structure as chance and the whim of the author may dictate: „Bizarr, eigensinnig, phantastisch, leicht witzig, geschwätzig und sich ganz in Darstellung auch von Nebensachen verlierend, tragisch wie komisch, tiefsinnig und neckisch, alle diese Farben und Charaktere läßt die echte Novelle $z u$, nur wird sie immer jenen sonderbaren auffallenden Wendepunkt haben, der sie von allen anderen Gattungen der Erzählung unterscheidet “' 2 ). This is certainly retrogression from A. W. Schlegel's strict requirements in the matter of concentration on the central theme. Indeed from our point of view at the present day this sentence sounds almost like a tart bit of ironic selfcriticism. A better summary of Tieck's weak and strong points could hardly be gathered into a single sentence.

In Tieck's novellen dialog in the form of discussion and debate plays a most important part, and this side also of his technic is here touched upon: „Es wird sich auch anbieten, daß Gesinnung, Beruf und Meinung, im Kontrast, im Kampf der handelnden Personen sich entwickeln, und dadurch selbst in die Handlung übergehen. Dies scheint mir der echten Novelle vorzüglich geeignet, wodurch sie individuelles Leben erhält"“3). Nowadays we relegate such discussion to the novel as unsuitable in a form demanding extreme concentration upon the central theme, but just here, as also in the dictum that the present is quite as worthy of poetic treatment as the past, Tieck joins hands with the authors of the Young German movement whose work, poetically of comparatively little intrinsic value, marks nevertheless a decided advance toward modern realism ${ }^{4}$ ).

Despite the important role played by dialog in his novellen, despite the fact that his Vogelscheuche is actually divided

1) Schriften, XI, p. LXXXVII.

a) loc. cit. LXXXVII.

3) loc. cit. LXXXVIII.

4) See below, p. 47 and p. 5 I f. 
into acts and scenes and Der Geheimnisvolle was first conceived as a comedy ${ }^{1}$ ), Tieck did not feel the affinity between the novelle and the drama which had been so keenly present to A. W. Schlegel. Some years before the appearance of the preface here under discussion, in a review of Körner's Tony ${ }^{2}$ ), he finds on the contrary that it is most difficult to dramatize a novelle with any success, and he points out that Shakespeare never based a play upon a really good novelle. „In der Erzählung muß Zeit und Ort beständig anklingen, um so mehr, als es Altertum oder ferne Gegend ist; das Detail der Umstände macht die Spannung, die sich des Gemütes bemeistert, sanft und künstlerisch; die hereinbrechende Entwicklung, die unvorhergesehenen Zufälle und Personen, die oft dem Anfange widersprechen dürfen, das Anknüpfen der Hauptbegebenheit an Kleinigkeiten, ihre Lösung durch nicht $\mathrm{zu}$ berechnendes Ungefähr: alles dies kann der Erzählung Reiz und wunderbaren Charakter geben“"3). In the drama, however, the past is of necessity present before our eyes and careful dramatic motivation gives mere chance little scope. With A. W. Schlegel Tieck finds that the story teller may be taken at his word (and here chance and "wonder" may play a large part), but no such privilege is accorded the dramatist, of whom we demand verisimilitude through careful motivation ${ }^{4}$ ). The admission of this element of chance in the one genre and its exclusion in the other forms for Tieck an impassable gulf between the two. He can not see with Schlegel and Spielhagen how closely related they are, viewed from another angle.

Subconsciously perhaps, though it would almost seem deliberately, Tieck has sought in this utter segregation of the novelle as a literary species to give it a place not less exalted than the drama or the novel. Like them it has its mission, its.

1) loc. cit. LXXXIV.

$\left.{ }^{2}\right)$ Dramaturgische Blätter. 3 Bde., Breslau 1826 u. I852, I, 124 f.

$\left.{ }^{3}\right)$ op. cit. I, I 29.

4) op. cit. III, 227, a review of Oehlenschläger's Correggio. The same thesis - ,eine dramatisierte Erzählung ist noch lange kein Drama" - is defended in the review of Auffenberg's Der Löre von Kurdistan, op. cit. III, $214 \mathrm{ff}$. On the other hand the debt of Tieck in many of his novellen to the dramas of Calderon and Lope de Vega was by no meansinconsiderable. Cf. J.-J. A. Bertrand, L. Tieck é le théatre espagnol, Paris 1914, pp. 146-166: Le théâtre espagnol et les nouvelles de Tieck. 
high moral import, but dealing as it does with the unusual, the abnormal in life, it may rightly insist on being judged from an ethical standpoint which admits exceptions: „.. . . . . so kann die Novelle zuweilen auf ihrem Standpunkt die Widersprüche des Lebens lösen, die Launen des Schicksals erklären, den Wahnsinn der Leidenschaft verspotten, und manche Rätsel des Herzens, der Menschentorheit in ihre künstlichen Gewebe hineinbilden, daß der lichter gewordene Blick auch hier im Lachen oder in Wehmut, das Menschliche, und im Verwerflichen eine höhere ausgleichende Wahrheit erkennt. Darum ist dieser Form der Novelle auch vergönnt, über das gesetzliche $\mathrm{Ma} \beta$ hinwegzuschreiten, und Seltsamkeiten unparteiisch und ohne Bitterkeit darzustellen, die nicht mit dem moralischen Sinn, mit Konvenienz oder Sitte unmittelbar in Harmonie stehen'1). As among German poets Tieck was the first to come to best and highest expression in the novelle, so among critics he was first to raise the form to a preëminent and independent position in literature.

In the theory of the novelle the work of Theodor Mundt marks the transition from the purely aesthetic literary standards of Goethe and the Romanticists to what might be called the purely propagandist standards of the Young German movement. Fortunately the bulk of his critical work in this particular field falls within the period before 1834 , while he was still interested in the form as a literary genre. In the years 1826-27 Mundt published no less than five novellen in the literary supplement of a Berlin paper ${ }^{2}$ ), and in $1827-28$ a series of six critical articles dealing with the history and theory of the novelle also reached the public through the pages of the newspaper ${ }^{3}$ ); - all this while the author was still a student at the University of Berlin.

1) Schriften, XI, p. XC.

2) Cf. Otto Draeger, Theodor Mundt und seine Beziehungen zum fungen Deutschland, Diss. (Teildruck), Marburg 1908, p. 6. The five novellen, all mediocre products of the Romantic type, appeared serially in the Beiwagen zur Berliner Schnellpost, $1825-27$.

2) Cf. Draeger, op. cit. $6 \mathrm{f}$. The articles in question are:

1. Über Ludwig Tiecks Novellen, Berliner Schnellpost, Beiwagen, 1827. Nrs. 2-4. Reprinted in Kritische Wälder (1833), I62 ff.

2. Die Poesie der Sagen, Märchen und Novellen, Berliner Konversations-Blatt, 1828, Nr. 25. 
We know that he planned an exhaustive monograph with the title Geschichte der Novellenliteratur and that the plan was not finally relinquished till I834, when he joined in the Young German movement ${ }^{1}$ ), but what proved to be his last word on the theory of the novelle from the viewpoint of aesthetic criticism appeared in his Kritische Wälder (I833) under the title Uber Novellenpoesie ${ }^{2}$ ).

Here he shows that the novelle had its origin in Italy and was developed from the anecdote: ,Aus der Anekdote hat sich die Novelle zu einer poetischen Produktion erhoben, sie hat sich durch Cervantes zuerst zu einem eigentümlichen und vielseitiger gestalteten Kunstwerk ausgebildet, aber ihr ist immer der Unterschied vom Roman geblieben, daß sie mehr den Verlauf eines bestimmt gegebenen, in sich konzentrierten Verhältnisses, das sie bis zu einer Auflösung und Entscheidung bringt, darstellt, während dieser an einer Reihe von Verhältnissen die Bewegung des Lebens in die Ferne ausdehnt"3). „Die Novelle . . . . . ist gleichsam nur eine Episode aus dem Roman des Lebens, ein in sich abgeschlossener Mikrokosmos gegen den Makrokosmos eines ganzen, in allen seinen Teilen, auch dem Verlaufe der Zeit nach erschöpften Lebens. Wenn man den Roman mit seinen im Fortschritt der Zeit sich aneinander reihenden Begebenheiten einer Linie vergleicht, die sich in einer geraden Richtung und allmählicher Verlängerung fortbewegt, so ist die Novelle dagegen eine Zirkel-

3. Zur Geschichte und Kritik der Novellenpoesie, loc. cit. 1828, Nrs. 101-4.

4. Tiecks „Der Alte vom Berge", loc. cit. 1829, Nrs. 48 ff. Reprinted in Kritische Wälder, $150 \mathrm{ff}$.

5. Italienische Novellenpoesie, loc. cit. 1829, Nrs. I6I ff.

6. Über deutsche Romane und Novellen in ihrer Entwicklung, loc. cit. 1829, Nr. 2 I4.

I regret to say that these articles, with the exception of the two reprinted in the Kritische Wälder, proved to be inaccessible. However, the article here discussed is clearly a resume of of all Mundt's thought on the theory of the ncvelle and covers all essential points.

1) Cf. Draeger, op. cit. 7. Numbers 2 and 6 listed above were fragments of the projected monograph.

2) Kritische Wälder. Blätter zur Beurteilung der Literatur, Kunst und Wissenschaft unserer Zeit, Leipzig 1833, pp. 131-149: Über Novellenpoesie.

2) loc. cit. 133 . 
linie, die in sich selbst zusammengeht und die bestimmte Beziehung auf ein gewisses Zentrum hat, um dessentwillen sie da ist und ihren Lauf vollführt. Die Novelle behandelt ein von einer gesamten Lebenstendenz abgesondertes, einzeln für sich bestehendes Lebensverhältnis, auf dessen Verlauf und Entwicklung es zunächst abgesehen, und strebt von ihrem Anfange an zu einem notwendigen Schlusse hin, der aus dem Mittelpunkte des Stoffes organisch hervorgeht. Im Verhältnis zu einem solchen Schluß der Novelle ist der Schluß des Romans gewissermaßen mehr willkürlich, indem er sich gleichsam nur als letzte Begebenheit an eine Reihe von Begebenheiten, freilich zur vernunftgemäßen Befriedigung anschließt, das Leben der Novelle aber, als in sich gedrungenes und konzentriertes, keine große Bewegungen in die Länge der Zeit hinaus unternehmend, sich, wie schon bemerkt worden, in seinem Innern organisch zusammenschließt, somit ihr Schluß oder die Pointe, worauf die Begebenheiten hinstreben, und aus dem sich der Ausgang entwickelt, als das entschiedenste und ihrem Interesse wesentlichste Moment anzusehen ist; das Interesse des Romans hingegen nicht sowohl in dem Resultat des Ausganges, als in der fortlaufenden, mannigfach wechselnden Richtung des Lebens selbst im beweglichen Fortschritt der Zeit beruht. Der Roman beginnt gemeiniglich vom Ursprung der Dinge, von wo aus er seine lange Wanderung bedächtig antritt; die Novelle dagegen fängt zumeist mit solchen Verhältnissen an, die sich schon auf einer gewissen Bildungsstufe, oder in einem gespannten, leidenschaftlichen und erregten Zustande befinden, und sich aus einer bestimmten Sphäre herausentfaltend, durch eine gleichsam dialektische Bewegung nach allen möglichen Auswegen und Richtungen hin, zur Ruhe gebracht, vermittelt, ausgesöhnt oder vernichtet werden soll“" 1 ).

Fr. Schlegel and Schleiermacher had been badly confused as to the line of demarcation between the novel and the novelle, A. W. Schlegel too had failed to come to any clarity in the matter, and neither Goethe nor Tieck had raised the question at all; but. Mundt, apparently with no difficulty whatever, gives us the first satisfactory differentiation between the two forms in his simile

3) loc. cit. $140 \mathrm{f}$. 
of the straight line and the circle drawn about a given center. The question of bulk, which had earlier proven such a stumbling block, he simply disregards as immaterial. So sure is he of his position that he goes on to say that the novel and the novelle, both of them modern forms of the epic, are so essentially different that it is absolutely impossible to confuse them except in name, and that a confusion in name should not be allowed to lead to a confusion in genre. Thus Goethe's Wahlverwandtschaften, which centers about the conflict between duty and inclination, is essentially a novelle, but the complexity of the situation leads to an epic breadth of treatment which is not characteristic of the more compact structure of the novelle. „Dem ungeachtet bleibt die Anlage der Wahlverwandtschaften dennoch novellenartig, wenn man die Behauptung will gelten lassen, da $B$ Novelle und Roman zwei verschiedene Gattungen des Epos, zwei verschiedene künstlerische Konstruktionen sind, und zwar so verschieden, daß die Novelle die Dialektik nur eines einzelnen Verhältnisses und Lebensmomentes ist, das nicht weiter als nach den ihm innewohnenden, möglichen Richtungen entwickelt und fortgesetzt wird; der Roman aber ein Zyklus von Verhältnissen und Momenten ist, die sich allmählich in der Zeit aneinanderreihen, die sich in keinem zirkelförmigen Verlauf entwickeln und in sich zurückgehen können, die in die ferne $\mathrm{Zu}$ kunft des Lebens zu einem noch ungewissen Ziel hinaussteuern .... Goethe nennt sie einen Roman; der Name tut's freilich nicht, und man kann über die Pedanterie der Nomenklatur vornehm lächeln, aber auch ein Name muß sein Recht behalten, er muß nicht zufällig gewählt erscheinen“" ${ }^{1}$ ).

Mundt then undertakes to defend the title novelle for Tieck's Aufruhr in den Cevennen which, because of its bulk, had excited considerable discussion among the reviewers. Some had attempted to defend the title on the ground that the story lacks a "hero", which would be essential to the novel, but Mundt takes a very different position. He finds the story to be a novelle like any other, because its action revolves about a definite central point, only in this case the central point is a great historical event through which alone the actions of the various

1) loc. cit. $143 \mathrm{f}$. 
characters have any meaning. The definite close - which unfortunately was never added - would, on its appearance, justify the claim to the title ${ }^{1}$ ).

Another bulky novelle of Tieck, where the situation is still more complicated, he then proceeds to defend on the same grounds, but with the addition of a new element which he is the first to introduce into the discussion of the species: „In wiefern Novelle und Roman verschiedenartige Gestaltungen und Konstruktionen sind, zeigt sich besonders deutlich an Tiecks D i c h t e rle be n, das seinem biographischen Stoffe nach eine unverkennbare Anlage zum Roman in sich trägt, durch Darstellung und Behandlung aber in einer entschiedenen Form zur Novelle geworden ist. Das Leben der beiden Dichter Marlowe und Green ... . . erscheint, statt sich der Länge nach im allmählichen Fortgang der Zeit zu entwickeln, mit seinen Strahlen zusammengedrängt in den Kristallspiegl der Novelle. Der Charakter Marlowes und Greens ist schon in einer dem Anfang der Dichtung vorhergehenden Vergangenheit ausgebildet und angelegt, und wird bei ihrem Auftreten in . . . . . Reden und Gesprächen, die . . . . . den Ausdruck eines ganzen Gemütes durch und durch erschöpfen, nachgeholt. Sie tragen beide, schon bei ihrem anfänglichen Erscheinen, den Keim des Todes in sich, welcher in der ihm möglichen Richtung in seiner Blüte aufsteigt, und in schnellem Wachstum die Frucht der Vernichtung reift; für Marlowe mehr auf eine innerliche und geistige Weise . . . . ; für Green aber von der Eitelkeit des Lebens her..... So erscheint die Dichtung in sich abgerundet und konzentriert, und ist durch die Zusammengedrängtheit ihres Stoffes umso ergreifender in ihrer tragischen Wirkung, mit dem gleich daneben stehenden Gegensatze in dem hellen, freundlichen Bilde Shakespeares. Dies ist eine echt novellenartige Darstellung. Als Roman würde das Gedicht sich ganz anders gestalten müssen. Das Leben der beiden Dichter, das die Novelle als ein schon angelegtes und ihrem inneren Charakter nach völlig entschiedenes aufnimmt, und nur nach der ihm noch möglichen Entwicklung zu seinem Untergange entfaltet, würde der Roman erst in den Anfängen seiner Bildung aufsuchen, er

1) Cf. loc. cit. 144 . 
würde uns die Bildungsgeschichte dieser Charaktere nach äußeren und inneren Verhältnissen erst entwickeln und motivieren müssen, er würde mehr biographisch erzählen, während die Novelle mehr in pittoresken Bildern darstellt" $t^{\prime}$ ).

This conception of fixed characters in the novelle and still developing characters in the novel Spielhagen later took over as one of his two distinguishing criteria for the briefer form. The other was capability of dramatization, which he held to be inherent in every good novelle and lacking in the novel ${ }^{2}$ ), but this idea does not go back to the same source. Mundt does indeed assert that epic material cast in dialog form is not a drama, but an abortion ${ }^{3}$ ). However, in contrast to Spielhagen, he seems to have the novelle in mind here, for he goes on to condemn Goethe's dramas as novellen in dialog and as lacking in all that is specifically dramatic. For him the essential difference between the epic and the dramatic is the difference between passivity and activity: „Das Dramatische, wenn es seinem Begriff entspricht, zeigt das Individuum, wie es von der Energie des Lebens ergriffen, sich auf das Leben mit seiner $\mathrm{T}$ a $\mathrm{t} \mathrm{kr}$ a $\mathrm{ft}$ richtet; das Individuum des Dramas e r ze ugt und voll b r ing t $\mathrm{H}$ a $\mathrm{nd} \mathrm{l} \mathrm{u} \mathrm{ngen}$, das Individuum in einer epischen Auffassung erlebt Begebenheiten ....."4) Therefore Goethe's Tasso is not dramatic, but rather lyric-epic; Tasso's condition is the same in the end as at the beginning; the poet has not become reconciled with the world, but on the contrary, the gap between them has only become wider. „Daher fehlt dem Stück durchaus aller AbschluB und einer wahrhaft dramatischen Entwicklung ist gerade der bestimmte AbschluB eigentümlich, zu dem die handelnden Personen, die Verwicklung ihrer Verhältnisse zu durchbrechen, hinstreben, in dem ihr Streben seine Ruhe und

1) loc. cit. I45 f. A. W. Schlegel had already touched upon the idea that characters in development belong rather to the novel (see above, p. I7), but he advances the idea in explanation of the relative bulk of the two forms, while both Mundt and Spielhagen (cf. p. 19, note 2) make of it a chief distinguishing characteristic.

2) Cf. p. 19, note 2 and p. 20, note 2. A. W. Schlegel (see above, p. 17) was not prepared to go so far in this matter as Spielhagen.

3) Cf. Kritische Wälder, 146.

4) loc. cit. 147. The spacing is Mundt's. 
Lösung findet"1). Oddly enough Mundt fails to see that he has hit upon one of the connecting links between the drama and the novelle, for earlier in the essay he has designated this definite ending, toward which all the action moves, as an essential element of the novelle. But his whole endeavor centers upon separating the different genres even within their various groups, and he closes the essay with a condemnation of dramatized fairy tales, which drag all that is dreamy and imaginative into the world of reality, where its charm is lost.

For Mundt then the novelle is very definitely a species which is essentially distinct from every other. It is a story built up around a given central theme and rounded to a definite close, the nature of which is organically inherent in the central theme and is determined by it. The novelle deals with a single, definite, self-centered situation which it brings to a definite solution at the close, and herein it differs essentially from the novel, which deals with a series of situations and closes as it may. An unusually complex situation may demand unwonted breadth of treatment, but mere bulk has nothing to do with the essential nature of the story. Mundt's utter independence of his predecessors has the advantage that multiplicity of detail has not blinded him to the main issue, which, as he rightly discerns, lies in the fixing of the outer form of the species; but it also has its disadvantages. He misses, for instance, the affinity between the novelle and the drama, and also the element of paradox in the novelle, which had occupied his predecessors without exception and had furnished Tieck with the very core of his theory. On the whole, however, Mundt's theory is by all odds the fullest and clearest general statement before $185^{\circ}$, and it is especially valuable for its excellent distinction between novelle and roman, a difficulty which no one before him had attacked with any success.

\section{Theory of the Novelle from Young Germany to Heyse:} $1834-1871$.

The years between the appearance of Mundt's Kritische Wäl der (I833) and Heyse's introduction to the Deutscher Novellen.

1) loc. cit. 148 . 
schatz $(\mathrm{I} 87 \mathrm{I})$ are, indeed, barren of any contribution to the theory of the novelle that is of really prime importance. Nevertheless, what did appear in these years is deserving of study, for it reflects with all accuracy the fall and rise of aesthetic standards in the literature of the time. Here and there some slight additions are made to what has gone before, or some good point attains to clearer statement. To cast it all aside as negligible would seriously hinder a proper evaluation of Heyse's great services in fixing the form of a literary species which is perhaps Germany's most characteristic contribution to Igth century literature. The rise of a new sense of form in the middle of the century divides this period between Tieck and Heyse rather evenly into two halves which contrast very sharply with eachother. The first half is essentially the so-called Young German period, and what the critics of this time have to say on the theory of the novelle is most interesting because of their attempt to bring the theory of the species into line with certain phases of their new literary movement. It is virtually an attempt to square the older theory with the younger practice, and it is not surprising that the attempt was unsuccessful at a time so lacking in sense of form, whether judged by the standards of either an earlier or a later day.

The novelle played a larger part in the beginnings of Young Germany than any other form of literature, and it came in for criticism almost immediately after the inception of the movement. This is usually dated from the appearance of Ludolf Wienbarg's Ästhetische Feldzüge in the spring of 1834, though as a matter of fact Wienbarg did little more than furnish a set program for certain literary currents which had already been apparent for some time, in the work of Gutzkow for instance, and point out the direction which, as he thought, these currents were to follow. For Wienbarg the novel (roman), not the drama, is the great literary genre of the future as well as the one best suited to the needs of the movement with which he has cast in his lot. But his friend Theodor Mundt finds in the novelle a form still better suited to the immediate purposes of the younger generation as a bearer of their social and political propaganda: „Die Novelle nistet sich noch am meisten in Stuben und Familien ein, sitzt mit zu Tische und belauscht das Abendgespräch, und 
man kann da dem Herrn Papa zur guten Stunde etwas unter die Nachtmütze schieben oder dem Herrn Sohn bei gemächlicher Pfeife eine Richtung einflüstern, die vielleicht einmal für die ganze Nation Folgen haben mag. Die Novelle ist ein herrliches Ährenfeld für die politische Allegorie . . . . . Die Novelle steht sich mit der Polizei besser, und sie flüchtet sich auf die Stube, wo es keine Gendarmerie gibt . . . . Mitten in der Trägheit der Novellenleserei, wo er [der Deutsche] recht zu faulenzen glaubt, muß sie ihm einen Floh ins Ohr setzen . . . . . So fasse ich die Novelle als deutsches Haustier auf, und als solches ist sie mir jetzt die berufenste Kunstform, das Höchste darzustellen" ${ }^{1}$ ). It was precisely in this sense that the novelle played a most important part in the activities of the Young Germans up to about 1840 , when the drama came to be their favorite form of expression, if not their chief vehicle for propaganda ${ }^{2}$. That Wienbarg showed the keener discrimination and the finer aesthetic sense in thus relegating discussion and debate to the novel, is beside the point, but it is interesting to note in passing that the Young Germans failed to produce a single novelle that has other than historic interest for the present day. Like Tieck they failed to see that discussion of the questions of the day lies outside the province of a literary species, one of whose chief characteristics is its conciseness.

The passage just cited shows how definitely Mundt had left the aesthetic standards of his Kritische Walder behind him and how completely he had gone over to the standards of the Young Germans. The change was, however, not quite as sudden as would appear at first sight. The articles in the Kritische Wailer (1833) which deal with the novelle all go back to an earlier date $(1827-29)^{3}$ ), and they represent a stage in Mundt's critical development which he had begun to leave behind him as early as 1830 , three years before the volume of collected essays appeared. The transition to the Young German stand-

1) Th. Mundt, Moderne Lebenswirren. Briefe und Abenteuer eines Salzschreibers, Leipzig 1834, p. I56 f. Cf. H. H. Houben, Fungdeutscher Sturm und Drang, Leipzig 1911, p. 446.

2) Cf. H. H. Houben, Heinrich Laube als Novellist, Beilage zur Allg. Ztg., 1906, Nrs. 212-213.

3) Cf. p. 38 , note 3 . 
point is evident in a letter to Brockhaus of April 21, I830: „Ich hoffe durch diese Novelle besonders deshalb Eingang beim Publikum zu finden, weil das Thema derselben, welches das Verhältnis der Musik zur Zeit behandelt, sich so enge an die Interessen der Gegenwart und beliebte Tagesbeziehungen anschließt. Ein solches Thema mußte ebensosehr einen bunten pikanten Novellenstoff hergeben (Schicksale berühmter Sängerinnen, satirisch aufgefaßt, Porträts und Modewelt und dgl.) als es von der anderen Seite durch seine Bezüge auf Kunst und Leben in das Gebiet einer zeitgemäßen Reflexion führte, die, wie es scheint, heutzutage von der Novelle nicht mehr ausgeschlossen werden darf .... "1).

The "Novelle" in question is Mundt's first novel, Das Duett, written in 1829 but not printed till I83I. Here the influence of Tieck's Musikalische Leiden und Freuden is everywhere apparent, especially in the role played by mere chance (zufall), in the lengthy reflections of the author, and in the constant reversion to the discussion of topics of current interest ${ }^{2}$ ). As we have already $\operatorname{seen}^{3}$ ), there is an intimate connection between Tieck's idea that the present is eminently worthy of poetic treatment and the Young Germans' conception of ,,das Zeitgemäße". It is significant that Tieck's preface to his collected novellen appeared only a year before Mundt's change of front in the letter to Brockhaus. Four years later his transition to the Young German attitude toward literature was complete.

In contrast with Mundt (in his Young German phase) Laube is interested in the novelle for itself as a literary form. He attempts to compare it with other forms and to mark the boundary between it and the novel. To this end he attempts to trace its development historically from the Italian novella and the German schwank down to the work of Tieck: „Der Begriff Novelle ist allmählich ein so weiter und vager geworden, daß es sehr schwer ist, seine vielen Richtungen unter eine gemeinschaftliche Beziehung zu bringen. Vielleicht war er anfangs das Söhnlein der Einfachheit ..... In dem tiefen Sumpfe unserer früheren Erzählungsliteratur erinnerte man sich jener kleinen, verführe-

i) Draeger, op. cit., I3.

$\left.{ }^{2}\right)$ loc. cit., $14 \mathrm{f}$.

2) See above, p. 36 and note 3 . 
rischen Geschichten des losen Boccaccio, die da Novellen hießen ..... Man bemühte sich, einfache Geschichten zu schreiben ..... Man ging noch weiter und schob die Begebenheit ganz in den Hintergrund, suchte die gewöhnlichen Verhältnisse hervor und stellte die Gedanken der Menschen, ihre Entwicklung und Einwirkung in den Vordergrund. So entstanden die rationellen Erzählungen .... . wo die Menschen als Körper ganz verschwanden und Systeme miteinander verkehrten, glücklich oder unglücklich wurden, Hochzeit machten und starben .... . Tieck . . . . hat doch so viel gesunde Sinne, und so viel sinnliche Gesundheit, $\mathrm{da} B$ er diesem Kasteiungswesen nie ganz verfiel - er schrieb seine schönen Novellen, und sie sind zumeist als Typus der bis jetzt noch herrschenden besseren Erzählungsform geworden.

Novelle und Roman verhalten sich in einer Hinsicht zu einander wie Romanze zu Ballade. In der Ballade und im Romane ist die Begebenheit selbst die Hauptsache, in der Novelle und Romanze die Begebenheit, wie sie e mpfunden wird. Die Novelle beschäftigt sich mehr mit dem Werden, der Roman mit dem Gewordenen. Die Novelle e $\mathrm{n} t \mathrm{w}$ i c k e $1 \mathrm{t}$ mehr Gegebenes, der Roman $\mathrm{s} \mathrm{ch}$ a $\mathrm{f} \mathrm{t}$ mehr. Sie bilden zusammen die Ehe eines heißen, fruchtbaren Weibes des Südens mit einem klaren, geläuterten Nordländer. Das Weib, der Roman, ist die Empfindung, der Mann, die Novelle ist der Gedanke. Ich halte darum die Roman-Novelle für die vollendetste Form dieser Gattung. Sie kann dem größeren Reichtum des Romans der größeren Klarheit, Einfachheit der Novelle zubringen" 1 ).

Of Laube's predecessors Mundt alone had succeeded in making the line of demarcation between roman and novelle at all clear, and it is not surprising that Laube, too, should fail. In times of revolution in literature there is always a lack of that aesthetic clearness of vision which allows the different genres to stand out sharply. It is at any rate a fact that this particular boundary line remained blurred throughout the Romantic and Young German periods and attained to clear definition only with the dawn of a revived sense of form at the middle of the century ${ }^{2}$ ).

1) Zeitung für die elegante Welt, 33. Jhg. (1833), Nr. I08, p. 429 f.

2) Mundt's excellent differentiation between the two genres, in the Kritische Wälder, is the single exception. Apparently it made absolutely 
Laube's idea that the novel is creative, while the novelle, rather develops given characters and situations, was later to be revived and further developed by Spielhagen ${ }^{1}$ ) to serve exactly this same purpose of differentiating the two forms, but Laube quite fails to grasp the potentialities of the idea and lets it go at a bare statement. Utterly bizarre and most characteristic of the aesthetic confusion of the day is his contention that the ,RomanNovelle" would be the perfect form for fiction. Only at a time when literary aesthetics is at its lowest ebb could one of the leading critics of the day hazard a statement so glaringly indicative of an absolute lack of appreciation for even external literary form ${ }^{2}$ ). The statement came, to be sure, just at the time when the reaction against Romanticism was most violent and was carried to the most extreme exaggeration. Some fifteen years later a better and saner sort of criticism was to flow from Laube's ever active pen, when the young revolutionists of his group had become leaders of assured position in literature, and when what he styles the "Romantic Dogma" had been definitely banned to oblivion.

Like a faint reminiscence of A. W. Schlegel's dictum that the novelle must depict men and conditions as they really are, without idealization ${ }^{3}$ ), and Schleiermacher's permitting the novelle alone ,das Gemeine und Unwürdige mit auf den Schauplatz zu bringen“" $)$ is Laube's: „Die Novelle bedarf keiner Vorzüglichkeiten ..... Sie ist die Lehre von der Gleichheit vor dem Angesichte der Kunst, denn sie schildert alles. Eine Figur, die zum Helden zu schlecht, zum Bösewicht zu gut ist, war früher

no impression on contemporary critics, and even of late years it is almost never referred to. From what follows it is evident that Laube was not acquainted with it, strange as that may seem in view of his intimate association with Mundt.

1) Cf. p. 22, note 3. The idea was originated by A. W. Schlegel and first fully developed by Mundt. Laube seems to have worked it out independently, and Spielhagen to have taken it over without giving any of his predecessors credit for it.

$\left.{ }^{2}\right)$ But cf. Richard M. Meyer's review of C. Alphonso Smith's Amerikanische Literatur in Euphorion, XX (1913), $292 \mathrm{f}$., where he risks the following remarkable statement: "Mir scheint die rechte Short-Story doch eine Vereinigung von Roman und Novelle, ein gleichsam nachträglich zur Novelle kondenzierter Roman: die Entwicklung des Romans mit der Moment-Technik der Novelle zusammenzubilden, ist, glaube ich, ihr eigenstes Problem."

3) See above, p. 18.

4) Cf. p. I9, note' 1 . 
nicht zu brauchen, der Novellist kauft sie, beschreibt sie genau, um einen Beitrag zur Lehre vom großen, mannigfaltigen Mechanismus der Gedanken zu geben. Die Novelle begnügt sich mit den einfachsten Zuständen; sie ist nüchterner, aber reifer. Sie hat etwas Naturphilosophisches an sich und behauptet, daB alles, was ist, sich schön darstellen lasse" $\left.{ }^{\prime 1}\right)$.

Here we have another characteristic ailment of the early stages of the Young German movement: a surprising lack of selection. When later the revived sense of form begins to make itself felt in literature there is a decided swing of the pendulum in the opposite direction, and the writers of that day are equally given to over-selection. This is characteristic of Heyse, for example, in nearly all his work. There is no turning away from the present or from reality, but the poet is over cautious to avoid all that is coarse and unlovely in his depiction of life in this workaday world. The result of such an attitude was ultimately a superrefinement in choice of subject and in technic which led directly to the Naturalistic revolt of the eighties with the attendant over-emphasis of all that is brutally ugly and degrading in modern life. And so the circle back to under-selection was complete.

Laube here seems, however, in the light of later developments, rather to be taking a more or less conscious step toward modern realism than seeking to establish a trait characteristic of the novelle alone. It is true that the brief tale in prose attained realism long before the novel. It is the older form, and it is oral and vulgar in its origin; it has always clung to the real despite its love for the unusual. Even in the thirties the novelle was already sharing with the novel this tendency toward realism, and gradually during the course of the century realism has made its way into the drama and even, though to a lesser extent, into the lyric. Realism is now no longer exculsively characteristic of any single literary genre, though Laube at this time was not so very far wrong in claiming it for the novelle only, if that indeed be his purpose in the paragraph above.

3) Zeitung f. d. elegante Welt, 33. Jhg. (1833), Nr. 108, p. 430. 
Thus far Laube has been concerned only with the attempt to define a literary species, apparently without ulterior motive, but now the Young German comes to the fore: how can the novelle be moulded to the service of the new movement; what is its raison d'être, its purpose? "Im wesentlichen spaltet sie sich in die kurze, prägnante Erzählung, und dahin gehören die neuerdings aufgekommenen Genrebilder, eine Gattung, die einer flüchtigen Zeit vorzüglich zusagt, weil sie dem rasch Vorüberjagenden schnell und mit scharfen Zügen ein ganzes Bild vor Augen bringt - und in die Tendenzerzählung. Sobald die letztere nur [nicht?] zum Rechenexempel, zur pedantischen Schulstube verkehrt wird und somit alles poetischen Blütenstaubes sich entledigt, kann sie eine außerordentlich wichtige Erfindung neuer Form genannt werden"'1). He evidently realizes that the Young German novelle was lacking precisely in this ,poetischer Blütenstaub" so eminently characteristic of the best novellen from Boccaccio and Cervantes down to Eichendorff and Tieck, and he wishes to justify the product of his own day through its didactic tendency. In a preceding paragraph he expresses the conviction that the novelle must needs become critical in an epoch so eminently critical in its purpose ${ }^{2}$ ), and this again is solely in justification of the abundance of purpose and lack of poetic inspiration in the literary production of the group in which he was a leading spirit.

Another side of the Young Germans' program, one which was as fruitful for Igth century German literature as their educative propaganda was sterile, is their sincere purpose to bring about a closer contact between literature and everyday life and so to enlarge the scope of literature. We have seen that the point of contact between Tieck and the Young Germans lies precisely here in this resolve to reconquer the domain of the present for literature in direct opposition to the Romantic flight from the present to the past $\left.{ }^{3}\right)$. In closing the article under discussion Laube touches

1) loc. cit. 430 .

$\left.{ }^{2}\right)$ loc. cit. 430.: "Sie ist vollkommon das Ergebnis unserer Tage, die im kritischen Studium kreisen, sie ist die kritische Phase der Erzählung."

2) See above, p. 36 . 
upon this point, demanding for the novelle a more flexible form and a breadth of outlook commensurate with the growth of modern intellectual and social life: „Man hat meisthin keine Form für vollkommener gehalten als die Tragödie, und es kann die Novelle alle innere Gesetze der Tragödie in sich aufnehmen, und sie kann im Åußeren weniger beengt, sich viel fesselloser bewegen ..... Die Erfindung der schmucklosen, einfachen Novelle fällt in Deutschland mit einer Zeit zusammen, wo die Schriftsteller das höhere gesellschaftliche Leben nicht beachteten und sich nur im geselligen bewegten. Dieser Richtung war die friedlich, langsam entwickelnde Novelle mit ihren kleinen Schritten vollkommen angemessen. Unterdessen sind die Literaten Staatsbürger geworden, die Weltgeschichte ist größer geworden, denn sie hat mehr Teilnahme gefunden, alle Verhältnisse haben sich somit erweitert, die Schritte verlängert - die der Novelle sollen sich nun auch ausdehnen, die früheren Vorzüge sollen in weitere Kreise ausgebildet, die Erzählung soll einfach bleiben, aber reicher gemacht werden"1).

A year later (I834) Laube attacks the problem once again ${ }^{2}$ ), this time with less assurance in the correctness of his definition. He now finds that every author has his own idea of what constitutes a novel, and what a novelle. Though formerly he had found Tieck's novellen "beautiful" and had declared them typical of what is best in the prose tale, he now finds that this "Hauptschöpfer der neueren deutschen Novelle" is the cause of all the existing confusion, since he had called all his stories by the name novelle, from the earlier "Zeitnovellen" down to his Tod des Dichters (I834), which exceeds the bounds of the earlier definition $\left.{ }^{3}\right)$. In aiming at the all-inclusive definition Kleist's Erzählungen - he does not call them novellen -

1) Ztg. f. d. eleg. Welt (1833), p. 430.

2) Ztg. f. d. eleg. Welt, 34. Jhg. (1834), Nr. 137, p. 547.

3) Laube's attitude toward Tieck became constantly more disparaging, reaching its culminating acidity in the article Ludwig Tieck in the Moderne Charakteristiken (1835). Cf. Laubes Ges. Wke, hgb. von H. H. Houben, Leipzig o. J., XLIX, 284 ff. Calmer and more nearly just is his treatment of Tieck in his Geschichte der deutschen Literatur (1839-40), III, 173. ff. 
should be taken into account ${ }^{\mathbf{1}}$ ). He continues: „Der Begriff Novelle, wie wir ihn von Boccaccio erhalten haben, der Name selbst kommt fast mit dem überein, was wir früher einfach ,Erzählung' nannten. Es ist eine frisch und einfach dargestellte neue Begebenheit. Der Roman e n t w i c kelt Charaktere, Verhältnisse, Zeiten, die Novelle ste $11 \mathrm{t}$ s i e dar. Sie tritt auf, sie erscheint nie wie eine ganze Statue, ihr Zweck ist mehr die schöne Erscheinung. Der Roman, ein Produkt viel größerer innerlicher Bewegtheit, nimmt ein ausgedehnteres Moment in Anspruch. Es kann in der Novellendarstellung ebenfalls eine Entwicklung liegen, aber der Zweck ist ein anderer: sie will das Erscheinungsleben vorüberführen. Auch das Erscheinungsleben von Meinungen, Gedanken, geistigen Welten. Der Begriff Roman ist umfassender, er will das ganze Leben eines Kreises erschöpfen und als wichtigsten Teil die inneren Begebenheiten des Menschen, die Romantik der Seele. Man hat ihn oft neben die Romanze, und die Novelle neben die Ballade gestellt, und es ist viel Verführerisches darin; auch die Romanze ist ein Wald, der ins Freie führt, die Ballade ein freier Weg, der in den nachdenklichen Schatten der dichten Bäume leitet“'2).

Here Laube recedes from the position taken in the earlier article, where he compares the novel with the ballad, and finds on the contrary that it is the novelle which bears the closer relationship to the ballad, while the novel is more akin to the romanze..$^{3}$ It is surprising that the comparison of the novel with the epic, rather than with the romanze, did not immediately suggest itself to him. He retains the thought of developing and already developed character, in the novel and novelle respectively, stating it more clearly and precisely than for-

1) Even in his Geschichte der deutschen Literatur (1839-40) he still avoids the term novelle for Kleist's work and clings to erzählung. (III, 186)

2) Ztg. f. d. eleg. Welt, (1834), Nr. 147, p. 547.

3) Despite the statement: „Man hat ihn [den Roman] of $t$ neben die Romanze und die Novelle neben die Ballade gestellt", I have found no critic associating the novelle and the ballad, with the single exception of Goethe (see above, p. 29), till long after this date. Today this comparison has become a commonplace of criticism. Modern works on poetics no longer attempt to distinguish between romanze and ballade. 
merly. A. W. Schlegel had already developed this idea in his search for a characteristic element present in novelle and drama, but absent in the novel1); however it must be remembered that the Berlin Lectures, though delivered in I80I-1804, did not appear in print till $I 884$, and so Laube may well have come to this conclusion independently. The idea that the novelle may treat of ,das Erscheinungsleben von Meinungen, Gedanken, geistigen Welten" is doubtless rather of a piece with that phase of the Young German program, which demanded an enlarged content for literature, than a return to the bloodless unrealism of the tales which flourished under Rationalism, and which Laube himself had condemned only a year earlier.

As time goes by Laube seems to grow ever more keenly concious of the disparity between the type of novelle produced under the Young German régime and that of the Romanticists, Goethe and Kleist. At any rate he is quite dissatisfied with his own attempt so to define the term novelle as to include both the earlier type and that of his own day. In the Moderne Charakteristiken (I835) he makes the statement that from Goethe's Wilhelm Meister the principle had been deduced that the hero of a novel must be passive, not active, that he may be held responsible only for his intentions ${ }^{2}$ ). And this is not his only quarrel with the Bible of the Romanticists: "Wilhelm Meister ist auch mehr oder minder Veranlassung geworden zu dem berühmten Schisma zwischen Roman und Novelle, dessen erschöpfende Definition auf ein literarisches Concilium wartet. Es geht diesen Worten wie den Poeten und Dichtern, den Dichtern und Sängern und ähnlichen Verwandtschaften: jedes neue Individuum gebiert eine neue Definition.

Wenn wir historische Rücksichten nehmen, so müssen wir die Novelle eine Gattung des Romans nennen. Sie war ursprünglich eine kleine Erzählung, eine Neuigkeit, und das Tatsächliche, die äußere, wirkliche Welt war ihr Element. So hat Boccaccio und Cervantes Novellen gegeben. Der Gedanke, die Kombination

1) See above, P. I 7 and P. 49, note I.

2) Moderne Charakteristiken, 2 Bde., Mannheim 1835. II, 406. Houben's edition of the collected works unfortunately gives the second volume only in extract. 
derselben, das Räsonnement, lag nicht in ihrer Wesenheit, ein gewisses Eigenartiges war ihr natürlich. Der Roman aber, wie er sich in den letzten 40 Jahren bei uns ausbildete, war umfassender, äußeres und inneres Leben in allen Ausdehnungen vindizierte er für sich, das Erschöpfen war seine Bestrebung.

Und mit ihm sind wenige Veränderungen vorgegangen, aber im Begriffe der Novelle ist viel Verwirrnis entstanden. Ludwig Tieck nannte seine Erzählungen Novellen, in denen just das Räsonnement die Hauptsache, die eigentliche Fabel beiläufig war, und am Ende sind die Beziehungen so willkürlich durcheinander gebraucht worden, da $B$ es dem Laien fast unmöglich dünkte, sich aus der Verwirrung herauszufinden. Ursprünglich war die Novelle eine kurze, markige Form, und mancher sieht sie noch dafür an, den Roman in ihr zu einem gedrungenen Körper zusammenzudrängen, eine andere Richtung dagegen hat geradezu mit der Novelle den Versuch gemacht, den Roman geistiger, stoffloser zu machen. Indessen wird der Unsichere immer noch am besten zurechtkommen, wenn er sich unter der Novelle einen Ausschnitt des großen Lebenskreises denkt, es kann deshalb doch alles darin zu finden sein, nur schärfer, spitzer, kürzer, wiederum einseitiger, überraschender. Dies ist eine moderne Form der Novelle: das Leben schnell, in einzelnen Åußerungen und darin doch ganz, wenigstens als ein Ganzes zu finden. Die Genremalereien sind ihre Domestiken. Nach dieser Ansicht wären auch die ,Wahlverwandtschaften" eine Novelle ....."1).

Here for a third time Laube seeks to develop historically a definition for the novelle that will cover all existing types adequately. $\mathrm{He}$ is constantly drawn to this form because of its intimate connection with the real world, its innate realism. But he is unwilling to admit the lack of form in the later type, for that is tantamount to admitting that the Young German novelle is no novelle at all. Throughout the entire discussion, however, one thing is clear amid all the confusion: he sees an essential difference between the novel and the novelle, not merely a difference in bulk. The only passage that could possibly admit any misinterpretation is: ,..... mancher sieht sie noch dafür an, den Roman in ihr zu einem gedrungenen Körper zusammenzudrängen."

1) Op. cit. II, $406 \mathrm{ff}$. 
But this is not his own view of the matter ${ }^{\mathbf{1}}$ ). He condemns Tieck for failing to live up to his own standards when he substitutes discussion for action in his novellen, and he seems to oscillate between demanding a more flexible norm for the postRomantic novelle and tacitly reproaching the product for not measuring up to Tieck's demands for the species.

Four or five years later in the course of his Geschichte der deutschen Literatur Laube attacks the problem for the fourth and last time. Here he mentions Goethe's ,viele kleine Novellen, um die dann später das etwas spröde rauschende Band der "Wanderjahre" geschlungen wird", and the Wahl verwandtschaften still seems to him essentially a novelle despite its bulk and the fact that Goethe himself labels it roman. On this point later criticism is inclined to agree with Laube, who gives good reasons for his view: ,Davon haben sie auch jetzt noch den Charakter der Novelle, wie ihn die jetzige Zeit definiert, als einer Begebenheit, eines Ereignisses, einer Schilderung, die sich um ein hervorstechendes Moment gruppiert, und wobei nicht wie beim Romane eine weit umgreifende Entwicklung beabsichtigt ist" ${ }^{\prime 2}$.

This is a good definition as far as it goes. It is by far the clearest statement that Laube ever made in the matter. Yet in his discussion of a contemporary, A. von Sternberg, he immediately confuses the issue again, and he characteristically fails to suspect that the trouble might lie rather in the product of his own day than with the standards of a previous generation.

1) Paul Pryzgodda in his Heinrich Laubes literarische Frühzeit (Berl. Beitr. z. german. und Roman. Philologie, German. Abt., Nr. 29) Berlin 1910, closes his discussion of these passages as follows; "In dem großen Streite um das Verhältnis von Roman und Novelle neigt Laube hier zu der Meinung, die beiden Gattungen seien nur dem Umfange, nicht dem Wesen nach voneinander verschieden, wie er es später in den ,Modernen Charakteristiken' deutlich ausgesprochen hat." This statement is, to my thinking, in direct contradiction to the evidence, particularly as we find it in the last sentence quoted from the Charakteristiken.

$\left.{ }^{2}\right)$ Heinrich Laube, Gesch. d. dtsch. Lit., 4 Bde. in 2, Stuttgart 1839-40, III, 407. The same idea had already been better developed by Mundt (see above, P. $4 \mathrm{I}$ ), and this would seem to show again that Laube was not acquainted with the Kritische Wälder. 
Sternberg's novellen, he says, ,,sind eben darin zum Unterschiede vom Romane Novellen, da $B$ ihnen dem Stoffe und der Idee nach eine volle Erledigung aller Konsequenzen des Themas versagt ist, und sie sind auch da immer am gelungensten, wo der Autor sich eines förmlichen Abschlusses begibt, und damit in jenem Punkte endigt, welcher für eine poetisch unfertige Zeit der einstweilige wirkliche Endpunkt ist .... . Was einer ganzen Geschichtsentwicklung obliegt, kann nicht einer einzelnen künstlerischen Produktion als unerlässliche Lösung zukommen ${ }^{1}$ " ". That is to say, form may be cheerfully sacrificed to content if only this content be in accord with the spirit of the time. A better illustration of the Young Germans' contempt for aesthetic standards in literature could hardly be found. For them such standards simply had no meaning, and so the Young German historian of literature, when passing judgment on his contemporaries, must needs discard every encumbrance of this sort. Accordingly Laube concludes lamely enough: ,Glücklichen Taktes hat sich auch die neue Zeit darum so vorzugsweise die Novellenform aufgesucht, die, ihrer alten Bedeutung entsprechend, wo sie einen vereinzelten Vorfall darstellte, jetzt eine unausgemachte Situation innerer und äußerer Ereignisse darstellen soll. Denn wie viel Unterscheidungszeichen auch aufgesucht worden sind, sie kamen entweder darauf hinaus, daß der Roman mehr ein größeres, in sich vollendetes Gemälde, eine vollständige Entwicklung zu geben habe, oder sie verirrten sich in Nebenkennzeichen. Eine durchgreifende Bestimmung ist noch nicht gegeben worden ${ }^{2}$ "“.

Perhaps the best comment on his unsuccessful struggle with this perplexing question is furnished by Laube himself as he looks back in later years (ca. 1875) upon the critical work of this period: „Meine Aesthetik selbst war recht wunderlich. Sie hat mir als abstrakte Wissenschaft nie Dienste geleistet; ich habe ihre Regeln immer nur erkannt und verstanden, wenn ich sie bereits getroffen oder verletzt hatte $)^{3}$ ". In the end, as we have seen, he was

1) op. cit. IV, I67. Note the sharp contrast to Mundt's demand for a definite close for the novelle (see above, p. $39 \mathrm{f}$.).

$\left.{ }^{2}\right)$ op. cit. III, 167 .

3) Erinnerungen (I. Teil: $181,-40$ ) Ges. Wke. (Houben), XL, 211. 
forced to renounce the attempt at a definition of this form which he felt to be so congenial to his purposes as a member of the Young German group. It seems to him that each period, if not each individual author in every period, must be a law unto itself. Consequently any search for a norm is destined to failure from the very start.

How general at this time the interest in this question was is shown by the fact that even authors as far as possible removed from all that Young Germany stood for, men, that is to say, quite without ulterior motive, are seeking for a criterion that will establish the novelle as a distinct and independent form. Such was Franz Grillparzer. In I839, with as yet only a single novelle in print (Das Kloster bei Sendomir, r828), he writes: „Unterschied von Roman und Novelle: Die Novelle ist das erste Herabneigen der Poesie zur Prosa; der Roman das Hinaufsteigen der Prosa zur Poesie. Jede gute Novelle kann man in Verse bringen, sie ist eigentlich ein unausgeführtes poetisches Sujet; ein versifizierter Roman wäre ein Unding. Daher im Roman die Begebenheiten vielfach vermittelt, in der Novelle positiv auftretend, so $\mathrm{da} B$ in ersterem die Ursachen vorherrschen, in zweiter die Wirkungen. Der Roman psychologisch, die Novelle psychopatisch; der Roman, wie schon Goethe bemerkt hat, retardierend, die Novelle fortschreitend ${ }^{1}$ )". Outwardly at least this statement shows all the confusion of the time, and though it contains a good idea or two, especially in the closing sentences, it adds no new element to the discussion, and consequently hardly demands extended comment and interpretation. A literal interpretation reduces to sheer nonsense such expressions as: "Jede gute Novelle kann man in Verse bringen, sie ist eigentlich ein unausgeführtes poetisches Sujet . .... or : „die Novelle psychopathisch“; and such thoughts as may be accepted literally had been more fully and clearly stated long before this time.

Another poet of this period, at least equally out of sympathy with the aesthetic standards of the Young Germans, was Friedrich Hebbel. Like Grillparzer, he knew that his real domain was

1) Studien II. Zur Ästhetik: III.. Zur Poetik, Nr. 99 (1839). Cf. Grillparzers Wke. hgb. von Stephan Hock. Berlin o. J. XII, $5 \mathrm{I}$. 
the drama, not the novelle $\mathbf{1}$ ), but his conception of the nature of the novelle was much sharper and clearer than Grillparzer's, and though he brings no new element into the discussion, still his conception is remarkable for its definiteness in a period of confusion and vagueness in critical standards. What he had to say on the theory of the novelle did not take shape as a full and lengthy formal statement, but between I835 and I860 his critical essays, diaries and letters show that his conception of the genre was essentially that of the Italians, Goethe and Tieck, and that he was acquainted with the theoretical statements of both the latter and accepted them on the whole, for he quotes them almost verbatim.

The first statement regarding the novelle in his diary (I835) is characteristic and not altogether promising: „Vorrede zum Roman: Gefühl, womit ich ihn schrieb: Novelle eine präzise Geschäftsreise, Roman-Pubikum eine dicke Kaffeeschwester ${ }^{2}$ )". And the essay Uber Theodor Körner und Heinrich von Kleist, written earlier in the same year, is scarcely more definite regarding the relation between the novelle and the drama: „Das Drama schildert den Gedanken, der Tat werden will durch Handeln oder Dulden; die Erzählung ist eigentlich schon keine reine Form mehr, sondern ein Gemisch des lyrischen und dramatischen Elements, welches sich vom Drama dadurch unterscheidet, daß es das äußere Leben aus dem innern entwickelt, während bei diesem das innere aus dem äußern hervorgeht $t^{3}$ )". And further: "Ich hätte hinzufügen müssen, daß ich das Lustspiel nicht zum eigentlichen Drama rechnen kann, sondern unter die Kategorie dialogisierter Erzählungen bringen muß $\left.\beta^{4}\right)$."

1) Letter to Elise Lensing, Easter $1836:, \ldots \ldots$ da ich um die Ehre, als deutscher Novellen-Dichter mit genannt zu werden, blutwenig gebe." Fr. Hebbels Sämtliche Werke, hist.-krit. Ausg., hgb. von R. M. Werner, Briefe I, 5 I. More than twenty years later Hebbel writes to Gutzkow in much the same vein: ,Ich machte von Ihrer Erlaubnis [Ihnen meine Novellen einzusenden] keinen Gebrauch, denn das Büchlein schien mir nicht bedeutend genug dazu, da es nur die ersten schüchternen Versuche eines sich selbst noch nicht verstehenden Talents enthielt, die wohl psychologisch, aber nicht artistisch ins Gewicht fallen." Br. VI, 8o. (15. Nov. 1857).

2) Tagebücher, I, Nr. 98. (8. Okt. I 835 ).

3) Wke., IX, 35 .

4) Wke., IX, 56 . 
Two years later (1837) he defends the right of the novelle to deal with what is unusual and exceptional: ,Goethe sagt mit Bezug auf Michael Kohlhaas, solche Fälle müsse man nicht im Weltlauf geltend machen. Das ist wahr, insofern man daraus keine Schlüsse zum Nachteil des Allgemeinen ziehen darf. Doch scheint mir, der Dichter muB eben auf Ausnahmen der Art seine Aufmerksamkeit richten, um zu zeigen, da $B$ sie so gut aus dem Menschlichsten entspringen, wie die Dutzend-Exempel1).“

In the following year (1838) Hebbel points out a defect in the technic of Tieck's novellen, for which, however, he at this time still has a hearty admiration: „Tiecks Novellen sind eigentlich durchaus didaktischer Art, aber es ist bewunderungswürdig, wie sehr bei ihm alles, was anderen unter den Händen $\mathrm{zu}$ frostigem Räsonnement gefriert, in den farbigsten Lebens-Kristallen aufschieBt. Auch das ist ihm ganz eigentümlich, daß er nichts zusammenbringt, was nicht unbedingt zusammengehört, was nicht zusammenkommen müßte, wenn es sich in seiner echten Wesenheit, in seiner Bedeutung für die Menschenwelt, entwickeln soll . . . . Dennoch möchte ich . . . . dieser Art der Novelle nicht den Preis zuerkennen .... S Sie kommentiert die Natur eigentlich mehr, als sie meines Erachtens soll und darf. Die höchste Wirkung der Kunst tritt nur dann ein, wenn sie nicht $f$ e $r \mathrm{ti} g$ wird; ein Geheimnis muB immer übrig bleiben und läge das Geheimnis auch nur in der dunklen Kraft des entziffernden Worts ..... Eben deshalb gehört ja das Didaktische, das ,beschränkte Sittliche' nicht hinein, weil es in der Idee den Widerstreit ausschließt, weil es nichts gebären kann, als sich selbst. Aber auch in der Novelle und Erzählung finde ich zu viel Licht bedenklich und gebe darum Kleists Arbeiten und Tiecks eigenen früheren den Vorzug 2)." It is significant that this element in Tieck's technic, which brings him into close touch with the Young Germans, appears to Hebbel an artistic blunder. As a critic his sympathies are all with the higher aesthetic standards of the Romantic period. At just about this same time another side of Tieck's technic is criticised by Hebbel, but whether adversely or not, is not quite

1) Tb. I, Nr. 720. (13. Apr. 1837.) Heyse takes much the same position in this matter; see below, p. 79 and note 3 .

2) Tb. I, Nr. I057. (3. Apr. I838.) 
clear: „Die einzige Spannung, die Tieck in seinen Novellen zu erregen sucht, wurzelt darin, daß man fühlt: die Menschen können nicht so bleiben, wie sie sind, deswegen betrachtet man auch alle Situationen, die anderswo die ganze Aufmerksamkeit in Anspruch nehmen, nur als Hebel und Schrauben, welche die innere Katastrophe herbeiführen solien. Ich glaube, Tieck teilt dem Roman die gewordenen, der Novelle die werdenden Charaktere $\mathrm{zu}^{1}$ )." Apparently this is meant as an adverse criticism, for a year later Hebbel condemns Scott's novels for their lack of character development. However he immediately proceeds to praise Goethe's Wahlverwandtschaften and Kleist's novellen for their keen psychology in the development of character ${ }^{2}$ ), and so it would seem that Hebbel makes no distinction here between roman and novelle, but rather is condemning any specimen of either genre that fails to lay emphasis upon the psychological.

Hebbel's never uncritical admiration for Tieck $^{3}$ ) was later (1847) turned into most disparaging criticism: „Eben durchblätterte ich Tiecks Novelle: Eine Sommer-Reise. Potz Tausend, Novelle! Achtung vor dem Publikum kann ein großes Talent nicht haben, aber hat es denn auch keine Achtung vor sich selbst? Von dem ProzeB, worin dergleichen Produkte entstehen, habe ich gar keine Vorstellung. Eine Erfindung drängt den Verfasser nicht zum Schreiben, denn es ist keine da, ein Charakter auch nicht,

1) Tb. I, Nr. 982. (10. Feb. I838).

2) ,Zum Teil zeigt er [Scott] seine undichterische Natur dadurch, daB er immer nur das Außere der Lebensprozesse, das Handgreifliche und in die Augen Fallende darstellt; überhaupt nur das Entwickelte, niemals das Werdende. Es ist freilich das Höchste, Seelenereignisse und Geistes-Revolutionen ohne Zergliederung und Beschwätzung unmittelbar durch das Tun und Leiden des Menschen zu zeichnen, wie es Goethe in seiner Ottilie, Kleist in seinen Novellen getan haben, doch, bei Scott geht innerlich gar nichts vor, seine Personen sind und bleiben, was sie sind, sie gewinnen oder verlieren wohl an Glück und Unglück, aber das Schicksal greift nie den Keim ihres eigenen Wesens an." Tb. I, Nr. I522. (4. März 1839).

3) As late as 1839 he still shows warm admiration for Tieck: ,Des Lebens UberfluB, neueste Novelle von Ludwig Tieck, macht auf innig ergötzliche Weise anschaulich, daß der reine Mensch dem Schicksal gegenüber immer seine Selbständigkeit $z u$ behaupten vermag, wenn er Kraft und Mut genug besitzt, mit der ihm aufgebürdeten Last zu spielen, sie als ein nur zufällig ihm nah gerücktes Objektives zu betrachten." Tb. I, Nr. 1498. (16. Feb. 1839). 
denn es tauchen nicht einmal Tapeten-Figuren auf, und eine Reihe interessanter Gedanken ebensowenig, denn es wird nur geschwatzt, wie beim Umbinden der Krawatte oder Anprobieren der Handschuhe. Woher die Beharrlichheit im Kontinuieren ?')"

Still later (1855) Hebbel compares his own novellen as a genre with those of Tieck, and to the disparagement of the latter: „Nächstens werden meine Erzählungen und Novellen .... . die Presse verlassen . . . . E Es sind das äußerst knappe, konzise Produktionen, die aus sehr verschiedenen Zeiten stammen, aber darin übereinstimmen, daß der Akzent ausschlieBlich auf Charakter und Situation gelegt ist, denn die Mischlinge, die zwischen Roman und Novelle hin und her schwanken und in denen Tiecks Alter sich so gefiel, habe ich nie gebilligt und es in meinen Epigrammen auch ausgesprochen $\left.{ }^{2}\right) . " \quad$ The epigram referred to closes as follows:

„In der Novelle dagegen vermag ich Dich nicht zu bewundern, Diese reizende Form hast Du erweiternd zerstört $\left.{ }^{3}\right) .{ }^{\text {. }}$

It must not be assumed, however, that Hebbel's conception of the novelle was confined to considerations of bulk or character development alone as criteria for determining the nature of the species. In the preface to his collected novellen, written in I84I but not published, he states that in practice his novellen follow the model of the older Italian novella, while his theory evidently is essentially that of Goethe: „Man erlaube mir bei Gelegenheit der wenigen Novellen, Erzählungen usw., die ich jetzt der Offentlichkeit übergebe, meine Konfession über die Gattung. Ich habe ihnen den Titel: niederländische Gemälde! vorgesetzt. Dadurch wollte ich andeuten, daß sie aus dem Leben, und zwar großenteils aus dem Leben der niederen Stände geschöpft sind. Nicht so, als ob ich wirkliche Vorgänge kopiert, oder auch nur zugrunde gelegt hätte, aber doch so, daß ich mich nach dem Vorbild der alten, stilkeuschen Meister alles dessen streng enthielt, was man in neuerer Zeit unter Dialektik verstehen gelernt hat, da $B$ ich also den Gehalt ausschlieBlich in die Erfindung und Charak-

1) Tb. III, Nr. 3880 . (3. Jan. 1847.) But in 1856 he says in speaking of Tieck's novellen: „...... Einiges davon [kann] den Kampf mit den Jahrhunderten ruhig aufnehmen." Br. V, 304.

2) Br. V, 253. An Fr. v. Uechtritz (25. Juli 1855).

2) Wke. VII, 228. 
terzeichnung, nicht aber im Räsonnement, oder gar in die Beschreibung zu legen mich bestrebte . . . . D Doch, das Epos hinterließ Söhne und Töchter: Roman, Ballade, Novelle. Auch dieser Formen, der einzigen, welche noch zur Erschöpfung und Darstellung ihres großen Gege n s a t z e s blieben, droht die Individualität, sich zu bemächtigen; man solle sie daraus entfernt halten! . . . . Die Novelle namentlich sollte, statt der Herzens- und Geisteszerfaserungen, worin sie sich mehr und mehr zu gefallen anfängt, die Begebenheit, die neue, unerhörte bringen und das aus dieser entspringende neue, unerhörte Verhältnis. Natürlich wird hier ..... unter Novelle nicht das entsetzliche Jelängerjelieber der Taschenbücher [verstanden] $\left.]^{1}\right)$."

Here Goethe's final definition of the novelle is given almost word for word, and it is repeated in the preface of 1844 , which was published together with the novellen: „Wenn ich übrigens Novellen im alten Stil bringe, solche, die durchaus auf die neue, unerhörte Begebenheit und das aus dieser entspringende neue, unerhörte Verhältnis des Menschen zu Leben und Welt gebaut sind, statt auf Herzens- und Geisteszerfaserungen, so sehe man hierin die tatsächliche Darlegung meiner Úberzeugung, da $B$ die Novelle keinen Fortschritt machte, als sie, sich scheinbar erweiternd, den geschlossenen Ring ihrer Form durchbrach und sich wieder in ihre Elemente auflöste ${ }^{2}$ ). " In the first of these prefaces Tieck's "Dialektik" meets with condemnation; in the second his expansion of the form of the novelle to the breaking point, an idea which appears again in the letter of 1855 and in the epigram on Tieck quoted above ${ }^{3}$ ). In 1838 , as we have seen, Hebbel had commented on the fact that Tieck portrays developing character in the novelle, and from these two prefaces he would seem to have reached the conclusion that the novelle is quite definitely unsuited as a genre to character portrayal, or at least that any detailed development or analysis of character is here out of place. The idea is by no means original with Hebbel, nor was he the last to enunciate it, but apparently he came to it independently.

1) Wke. VIII, $417 \mathrm{f}$.

2) Wke. VIII, $420 \mathrm{f}$.

') See above, p. 62 . 
In the end Hebbel's theory of the novelle became essentially a compound of both Goethe's and Tieck's. This becomes evident in a letter to Arnold Schoenbach of a date some ten years later than the published preface just cited: ,..... die Erfindung, die neue, unerhörte Begebenheit, welche dem Charakter plötzlich eine eben so neue und unerhörte Seite entlockt, ist und bleibt in der Novelle die Hauptsache ... . . Greifen Sie in die moderne Welt hinein und lassen Sie sich nicht einreden, daß unsere Zeit unpoetischer sei, wie irgend eine andere; es läßt sich mit Stoffen, ibr entnommen, nur schwerer täuschen, wie mit antiken und mittelalterlichen, weil die Vergleichung näher liegt und die Nullität leichter aufgedeckt wird ${ }^{\mathbf{1}}$."“

Though he contributed no new element to the discussion, it is at least evident from the foregoing that Hebbel had definite ideas on the theory of the novelle at a time when criticism in general was most confused, especially as regards this particular literary species. As late as $1855 \mathrm{Hebbel}$ himself finds little hope for fair treatment of his novellen at the hands of contemporary criticism: ,Die Novellen werden schwerlich gefallen, können es auch nicht wohl in einer Zeit, die sogar den Begriff der Gattung verloren hat $\left.^{2}\right)$.“

Just at the time when Laube was in the midst of his first struggle for a definition appeared Eduard von Bülow's Novellenbuch with an introduction by Tieck and a foreword by the editor of the collection. Tieck avoids the issue altogether, and Bülow does nothing more than give expression to the universal confusion of the time regarding a standard for the novelle: „Eine angenehme Überraschung würde ich empfinden, wenn diese meine Novellensammlung dazu beitrüge, über das eigentliche Wesen und den Begriff der Novelle klarere und festere Ansichten zu verbreiten, als die seither anscheinend allgemein bestehenden, und unter den beliebten sogenannten Novellisten unserer Tage und Stunden die falschgültige Meinung zu beseitigen, als dürfe man sich für berechtigt halten, jedwede breit vorgetragene Erzählung eine Novelle zu benennen. Von den Urhebern unserer neuen un-

1) Br. V, 2 I6. (10. März 1855.)

2) Br. V, 291. (30. Dez. 1855.) 
gleich vollendeter als jene alten Novellen sich erweisenden, wenn auch ursprünglich an ihnen èrwachsenen Kunstschöpfung dieses Namens abgesehen, erinnere ich mich keines einzigen Dichters untergeordneter Größe, außer Heinrichs von Kleist, der Novellen im Geiste der alten mit klarem Bewußtsein geschrieben hätte" Like Laube, Bülow (doubtless through Tieck) has come to something like a proper appreciation of the fine sense of form displayed by Kleist in his novellen, but he too hesitates to deduce from them any general laws governing the conception of the genre. Yet he hopes that his collection of stories from the different modern literatures will at least furnish examples of the practice from which the theory may be deduced, and so be a contribution, however modest, to the final solution of the question.

Soon after Laube had definitely relinquished all hope of a satisfactory definition Prof. O. L. B. Wolff in his history of the novel attempts to define this and the other most closely related forms of prose fiction. „,Die Erzählung unterscheidet sich dadurch vom Romane, daß sie nicht einen ganzen Lebenskreis und das Verhältnis eines Individuums innerhalb und zu demselben darstellt, sondern nur einzelne Ereignisse von eigentümlichem Interesse und deren dauernde Einwirkung auf den einzelnen Charakter, zu dem sie in besonderer Beziehung stehen, entwickelt und schildert .... D Die Novelle leitet bekanntlich ihren Namen aus dem Italienischen her und bedeutet ursprünglich nichts als eine gut erzählte Neuigkeit von allgemeinem Interesse, daher eine einzelne in sich abgeschlossene Begebenheit bestimmt und kurz, aber kräftig und lebendig vorgetragen, irgendeine Lehre des Lebens versinnlichend, ohne sie mit klaren Worten auszusprechen, oder wie bei der Fabel am Schlusse nachdrücklich mit wenigen Worten hervorhebend. So fassten Boccaz und seine Nachfolger sie auf, die Spanier dehnten sie aber zur Erzählung aus und die Franzosen folgten ihrem Beispiele. In Deutschland hat man nie das ursprüngliche Wesen derselben festgehalten; was wir so nennen ist ein $Z$ witter von Erzählung, Novelle und Roman, oft dies alles zusammen. Ein guter Roman ist nichts, als eine Reihe geschickt miteinander verknüpfter Novellen, aber eine Reihe zusammenhängender Novellen noch kein

1) Eduard von Bülow, Das Novellenbuch, 4 Bde., Leipzig 1834. Vorrede des Verfassers, I, p. XXV. 
guter, wenigstens kein kunstgerechter Roman, wie das z. B. Steffens Walseth und Leith beweist......"

Wolff's definition is adequate for the Italian novella, but he fails to point out that the expansion which the novella underwent in Spain and France was not necessarily only a question of bulk. In the case of Cervantes, for example, the development was rather toward a keener psychological penetration in the portrayal of character with a consequent expansion of the form. It was not true, even at the time this was written, that Germany had never held to the "original essence" of the novella, as Wolff might easily have convinced himself by a study of the work of Kleist, but it was unfortunately all too true of the novelle of the Young German period, which was doubtless chiefly what Wolff here had in mind. Goethe's Wilhelm Meister, then still the great norm for the novel in Germany, doubtless inspired the statement that the novel is nothing but a series of skillfully connected novellen. This is quite true for the early stages in the development of the species, as we find it in the Greek romances and in the medieval romances of chivalry, but when applied to modern literature Wolff's definition of both branches of fiction and his attempted distinction between them must be regarded as an utter failure. He quite misses that difference in the very essence of the two species which even Laube had felt, though it eluded him, and which Mundt had drawn so sharply in the Kritische Walder.

In the same year with Wolff's Allgemeine Geschichte des Romans (I84I) another professional student of literature published what has proven to be the most ambitious attempt at a theory of the novelle in this entire period. Georg von Reinbeck's Situationen: ein Novellenkranz contains, aside from a half dozen novellen long since forgotten, and that not undeservedly, an interesting preface of fourteen pages entitled: Einige Worte über die Theorie der Novelle ${ }^{2}$. The first three or four pages of this

1) O. L. B. Wolff, Allgemeine Geschichte des Romans von dessen Ursprung bis zur neuesten Zeit, Jena I $84 \mathrm{I}$, p. I $8 \mathrm{f}$.

2) Situationen. Ein Novellenkranz. Nebst einigen Worten über die Theorie der Novelle. Von Dr. Georg von Reinbeck, Kgl. Württ. Hofrat und Professor, Ritter des Ordens der Württembergischen Krone. Stuttgart 1841. Since the book 
treatise are devoted to a somewhat ponderous discussion of the various branches of poetry (lyric, epic, descriptive, didactic, dramatic), and the author comes slowly but surely to the conclusion that the confusion of the various divisions and subdivisions is a dangerous business, ,nicht bloß in der Theorie, sondern auch in der Praxis". This is especially true of the existing confusion between the two conceptions, novelle and roman, prevalent not among the reading public alone, but also among critics of repute. „Ja, wie weit diese Unkenntnis, oder auch Leichtsinn und Nachahmungssucht darin gehen, davon zeugt, da $B$ der Verfasser eines neueren Romans diesen sogar als - Romanze bezeichnet hat, wahrscheinlich weil der englische Namen für den Roman $\mathrm{R}$ o m a n c e ist, wobei er denn nicht bedacht, oder nicht gewußt hat, daß der Engländer für das episch-lyrische Gedicht, das wir wohl Romanze nennen, nur den Namen Ballade gebraucht, und folglich für ihn der Name $\mathrm{R}$ om a n ce eine eigentümliche und bestimmte Bedeutung hat, wenn er damit den Roman bezeichnet.

Der armen Novelle geht es aber überhaupt sonderbar. Wenn einige sie und den Roman für das einzig mögliche Epos der neueren Zeit erklären, ..... so wollen sie andere nicht einmal für Gedichte anerkennen."1). The fact, he continues, that most tales bearing the name novelle are poorly constructed and lack poetic inspiration, that they are written in prose to give the outward form an air of reality, must not be allowed to blind us to the just claim of the species to be classed as poetry. „Wenn die Novelle uns ein von der Phantasie nach einer Idee mit Absicht und Zweck zu dichterischer Wirkung freigeschaffenes Bild darbietet, so ist sie ein Gedicht, und ihr Verfasser ist ein Dichter ..... “2).

is as good as inacessible in America I quote from it perhaps more fully than Reinbeck's relative importance would otherwise warrant.

$\left.{ }^{1}\right)$ op. cit. p. XIV. Interesting in this connection is Tieck's comment on the similar abuse of the word novelle (see above, p. $33 \mathrm{f}$,). As late as 1846 J. Hillebrand speaks of "die novellistische Fruchtbarkeit" of Luise Mühlbach (Deutsche Nationallit., Hamburg u. Gotha 1845-46, III, 575). Even in the 3d ed. of the same work (1875) we meet with the expression: ,diese im Fache der Novellis tik überaus fruchtbare Dichterin" (III, 368), and mention is made of the „Reichtum ihres Novelle $\mathrm{n}$ fle i Bes" (III, 448).

2) loc. cit. XV. 
Having determined that the novelle belongs in the realm of literature and is hence worthy of serious critical consideration, Reinbeck proceeds to a definition: „Die Novelle ist eine poetische Erzählung. Eine poetische Erzählung ist die Mitteilung einer in der Menschenwelt möglichen Tatsache für die Phantasie als geschehen, um zu ergötzen oder zu erschüttern. Nicht jede poetische Erzählung ist aber eine Novelle. Es kommt dabei auf die Beziehung (Sphäre) an, in welcher eine solche Tatsache steht, dann auf die Verhältnisse, in welcher sie sich bewegt, und dann auf den größeren oder minderen Ümfang derselben. Steht eine Tatsache (Begebenheit) von größerem Umfange, in der sich also eine Reihe von Tatsachen $\mathrm{zu}$ einem organischen Ganzen vereinigen, in den höchsten allgemeinen Beziehungen der Menschheit, so bildet sie die Epopöe; steht sie in Beziehung zum Kulturleben, den Roman; zum Naturleben, das Idyll. Bewegt sie sich nicht bloß in den Verhältnissen der Menschen- und Naturwelt, wie die Wirklichkeit sie darbietet, sondern in einer von der Phantasie geschaffenen Welt, so entsteht die phantastische Dichtung (zu welcher auch das Märchen gehört, wenn diese Phantasiewelt eine Zauberwelt ist). Ist die Tatsache von minderem Umfange, begreift sie nicht Reihen von Tatsachen in sich, die sich zu einem organischen Ganzen vereinigen, sondern stellt sie eine einzelne Situation des Menschenlebens dar, so entsteht die poetische Erzählung im engeren Sinne, welche nach ihren Beziehungen und Verhältnissen verschiedene Namen erhält. Der Erzählung aus dem Kreise des Naturlebens bleibt der Name Idyll, sowie der aus dem Kreise einer Zauberwelt der Name Märchen; die aus dem Kreise des Kulturlebens aber erhält den Namen Novelle, die aus dem religiösen Kreise den Namen Legende, und die der Volks-Tradition angehörig den Namen Sage"1). By this thorough and very laborious process of elimination Reinbeck reaches the conclusion that the distinguishing characteristic of the novelle among all related epic forms is that it alone portrays a single situation in the real life of civilized man, whether it take the outward form of verse or prose. To avoid confusion with the ballad (and, by implication, with the anecdote, which however he may have relegated tacitly to the limbo of the unpoetic) he

1) loc. cit. XV f. 
continues: „Die Erzählung dagegen, welche nicht sowohl eine Situation, als einen einzelnen, in keiner weiteren Verbindung stehenden Vorfall mitteilt, behält den Namen poetische Erzählung par excellence, wie zum Beispiel, Der Handschuh' von Schiller, ..... Schwabenstreiche' von Uhland und ähnl. (Die lyrisch-epischen und episch-lyrischen, Ballade und Romanze, gehören nicht in die reine Epik, von der hier die Rede ist) "1).

The novelle having thus been contrasted with the other members of the epic group, Reinbeck proceeds to emphasize the two most important characteristics of the species: the element of the unusual and the concentration upon a central theme. "Die Erzählung, welche ergötzen oder erschüttern soll, muB Interessantes interessant erzählen .... E Ein ergötzendes oder erschütterndes Interesse wird aber nicht durch gewöhnliche Lebensvorfälle angeregt, sondern durch ungewöhnliche, in welchen ein menschliches Schicksal auf irgendeine Weise (heiter oder ernst) entschieden wird. Dies letztere, daß ein menschliches Schicksal entschieden werde, ist wesentlich zur Bildung eines Ganzen, zur Vollendung in sich; so wie, daß ein Mittelpunkt da sei, auf den sich unmittelbar oder mittelbar alle Einzelheiten beziehen. In einer Erzählung menschlicher Tatsachen kann ein solcher Mittelpunkt nur die Person sein, die bei der Entscheidung vorzüglich interessiert ist, insofern diese sie besonders trifft oder von ihr ausgeht. Man nennt eine solche Person den Helden der Erzählung“" $)$. In this thought that the central pivot in the novelle must needs be the hero of the story, Reinbeck has departed from Tieck's doctrine of the turning point (wendepunkt) in which the element of the unusual and, accordingly, the very essence of the novelle lies. From Tieck's point of view the hero of any sort of story may hold the center of the stage, but the one great characteristic of the novelle lies in the fact that the action somewhere takes a sudden turn leading to a conclusion not predicated by the beginning, yet, under the circumstances, perfectly natural. Later critics, with Heyse in the lead, have reverted to Tieck's theory of the turning point and have seen in it real in-

1) loc. cit. XVI.

2) loc. cit. XVIf. 
spiration. Indeed, Heyse's celebrated "Falcon Theory" is nothing else than this.

However Reinbeck, too, seems to feel that this element of the unusual should have strong emphasis, and he discusses the point at some length: „Bei jeder Tatsache der Menschenwelt entstehen aber die drei Fragen: Was ist geschehen? Wem ist es geschehen? Wie hat es geschehen können? Für alle drei Stücke müssen wir uns interessieren können, also für den ungewöhnlichen Verlauf, für die durch ihre Erlebnisse oder durch ihre Eigentümlichkeit, oder durch beides, ungewöhnliche Person, und für die ungewöhnlichen (inneren und äußeren) Verhältnisse. - Dieser ungewöhnliche Verlauf, diese ungewöhnliche Person-Eigentümlichkeit (die sich nicht bloß als Charakter, sondern auch als Empfindungs- und Äußerungsweise darlegt), diese ungewöhnlichen Verhältnisse müssen aber innere Wahrheit haben, das heißt, von der Phantasie als möglich können aufgefaßt werden: alles muß gehörig motiviert sein" "1). He then goes on to show that allegory, fable, parable and fairy tale may all have this same "inner truth", but they belong in the world of fancy, the novelle on the contrary in the world of reality. More specifically: „Die Novelle ist die poetische Erzählung einer Tatsache, welche als dem wirklichen Kulturleben eines bestimmten Zeitraumes angehörig erscheinen soll. Dies hat sie mit dem Roman gemein. Der Roman aber umfaßt einen bedeutenden Teil eines ungewöhnlichen Menschenlebens, ja wohl ein ganzes und oft mehr als e in Menschenleben: der Roman bildet eine poetische Biographie; dagegen hat die Novelle nur eine einzelne Erscheinung eines Menschenlebens, eine ungewöhnliche Situation zum Gegenstande. Wenn in dem Roman das Leben des Helden mit seinen mannigfaltigen Abwechselungen und Lagen interessieren soll, so soll das Interesse der Novelle sich dagegen auf eine einzelne Situation, als auf eine einzelne Tatsache konzentrieren. Welch ein bedeutender Unterschied wird daraus in der Behandlung hervorgehen" ${ }^{\text {"2). }}$

If the novel "embraces an important part of an unusual human life", then the element of the extraordinary would seem

1) loc. cit. XVII.

2) loc. cit. XVIII. 
to lapse as a preëminently important criterion for distinguishing the novelle from related forms. It is evident that Reinbeck does not attach the same importance to this phase of the question that Tieck did. The matter of concentration divides the novelle from the novel, but not from the drama, a fact which Reinbeck recognizes: „Durch diese Konzentrierung des Interesses auf eine einzelne Tatsache, in welcher ein menschliches Schicksal entschieden wird, nähert sich die Novelle dem Drama, bei welchem dies ebenfalls eintritt, daher auch aus einer Novelle leichter ein Drama sich bilden läßt (wie von Shakespeare aus den Novellen italienischer Dichter), als aus einem Roman; nur nicht aus jeder Novelle, weil bei dem Drama das Interesse vorzüglich auf die Erreichung oder Verfehlung eines bestimmten Zweckes und auf den Kampf dafür fälit, nicht aber so in der Novelle, wo es auf einen bestimmten $Z_{\text {weck }}$ und einen Kampf dafür nicht ankommt"'1). This last statement would hardly hold true for all cases, - not in Kleist's Michael Kohlhaas, for instance, whose structure is, indeed, dramatic ${ }^{2}$ ) - but it is an idea which neither A. W. Schlegel nor Spielhagen advances when discussing this point ${ }^{3}$ ).

Another element which the novelle has in common with the drama is the rapid forward movement of the action: „Ein Leben, auch das bewegteste, entwickelt sich nur nach und nach in einem längeren Zeitraum und hat mehrere Perioden; die Situation gehört einem einzelnen Zeitmomente an. Daher wird der Verlauf in der Novelle, wie im Drama, rascher vonstatten gehen, und das sogenannte epische Ausmalen und Verweilen, und alles, was nicht unmittelbar zur Tatsache gehört, wird wegfallen müssen, also alle Episoden, alle ausführlicheren Charakterzeichnungen und Schilderungen und Reflexionen und Räsonements, die schon im Romane leicht breit und langweilig werden . . . . Daß die Novelle eine Idee durchführt, darf ihre Natur nicht verändern; eine räsonierende Novelle - und wäre das Räsonement noch so geistreich — ist ein Unding .... . Die Novelle ist rein erzählend, und zwar

1) loc. cit. XVIII f. Mundt states precisely the opposite; see above, p. 40.

$\left.{ }^{2}\right)$ Cf. H. K. Becker, Kleist and Hebel, a Comparative Study. Chicago r9o4, p. $16 \mathrm{ff}$.

3) See above, p. I7 f. and P, 20, note I. 
vertritt sie, wie dies sich schon aus ihrer historischen Entwicklung bei Boccaccio ergibt, weit mehr als der Roman die mündliche Erzählung. Nun will der Zuhörer einer mündlichen Erzählung nicht wissen, was der Erzähler denkt und fühlt, sondern was geschehen ist, und das will er ohne Unterbrechung erfahren. Wenn daher der Roman, der mehrere Stadien durchläuft, seinem Interesse unbeschadet von Zeit zu Zeit aus der Hand gelegt werden kann, so würde es ein schlimmes Zeichen für den Wert einer Novelle sein, wenn dies eben so füglich anginge" ${ }^{\prime 1}$ ).

Much of Tieck's work, then, and practically all the novellen written under Young German inspiration, top heavy as they are with political and social propaganda, fall artistically below the standard set here by Reinbeck, and the critic of the present day can only agree with him. His notion that a novelle should be sufficiently brief to allow the reader to finish it at a sitting finds a striking parallel in a dictum of Poe, put forth shortly after this time. It is of course most improbable that Poe had ever heard of Reinbeck when he penned that famous essay on Hawthorne which laid the foundation for the theory of the short story in America, but the similarity of idea is peculiarly interesting. Poe says: "I allude to the short prose narrative, requiring from a half-hour to one or two hours in its perusal. The ordinary novel is objectionable from its length, for reasons already stated in substance. As it cannot be read at one sitting, it deprives itself, of course, of the immense force derivable from totality. Worldly interests intervening during the pauses of perusal modify, annul, or contract, in a greater or less degree, the impressions of the book. But simple cessation in reading would, of itself, be sufficient to destroy the true unity. In the brief tale, however, the author is enabled to carry out the fulness of his intention, be it what it may. During the hour of perusal the soul of the reader is at the writer's control. There are no external or extrinsic influences resulting from weariness or interruption"'2). Reinbeck is unique, in Germany, in discussing the length of the novelle from just this angle, but American theory and practice, follow-

1) Situationen, p. XIX f.

2) Works of Edgar Allen Poe, ed. by John Ingram. Edinburgh 1890, IV, $215 \mathrm{f}$. 
ing in the wake of Poe, have always stressed the matter of brevity after a fashion quite foreign to the German novelle down to the present day.

In conclusion, there is one heresy that Reinbeck hopes he has crushed for all time: the delusion that novelle and roman are essentially the same except in size. „Es erhellt also wohl, $\mathrm{da} B$ es eine irrige Einsicht ist, wenn die Novelle, wie gewöhnlich in unseren Poetiken, und auch von mir früher, als ein kurzer Roman bezeichnet wird. Manche Erzählungen sind allerdings kurze Romane, aber dann sind sie eben keine Novellen"1).

For all his verbosity Reinbeck has stated the matter rather well, and though modern criticism would certainly disagree with him in detail, still his statement as a whole is deserving of respect. Gervinus certainly regarded it in this light ${ }^{2}$ ), and Reinbeck surely deserves all credit for thinking and writing with clarity at a time when the boundaries between the different forms of fiction were blurred and critics were in revolt against the aesthetic laws laid down by classicism. Born in 1776 he had grown to manhood under the classic tradition, was accordingly not at all in sympathy with the formlessness of the Young Germans, and could approach the subject without their bias. He stood for form in a formless epoch, and so in the development of the novelle he would almost seem to be a forerunner of Hettner and Heyse. As a matter of fact, however, there is nothing to show that either of them knew his work or was influenced by it.

Just at the close of the first half of the century a new generation in literature was beginning to make itself felt, a generation

1) Situationen, p. XX. Prof. Brander Matthews (op. cit. 77) says, "As far as the author is aware, he had no predecessor in asserting that the Short-Story differs from the Novel essentially, - and not merely in the matter of length". This is probably a fact, as far as America and England are concerned, but evidently Reinbeck was his predecessor in Germany by a half-century, and even he was by no means the first to feel an essential difference between the two species.

2) G. G. Gervinus, Geschichte der deutschen Dichtung, 5. Aufl. hgb. von Karl Bartsch, Leipzig $187 \mathrm{I} \rightarrow 74$, V, 775: „Die Novelle verhält sich zum Roman wie die poetische Erzählung zum Epos, wie eine vereinzelte Begebenheit zu einer zusammenhängenden Handlung; sie ist wesentlich, wie sie ganz kürzlich Reinbeck noch genannt hat, eine Situation." (The first edition of Gervinus' work appeared 1835-42.) 
for whom form was the paramount consideration. And it is on the threshold of this new epoch that we meet with a satisfactory definition of the novelle which disregards the product of the Young German movement entirely and goes back direct to Tieck, giving incidentally with pregnant brevity an excellent distinction between roman and novelle. Toward the close of Hermann Hettner's work on the Romantic School, which appeared in I850, we find the following definition, all the more remarkable in coming, as it does, at the close of a long period of aesthetic chaos and before the new movement with its over-refined sense of form was well under way: „Das Wesen der Novelle besteht darin, daß, während der Roman die Totalität eines ganzen Welt- und Zeitbildes vor uns aufrollt, die Novelle ihrerseits sich auf einen einzelnen, großen oder kleinen, Vorfall beschränkt und diesen nach allen Seiten hin ins hellste Licht setzt. Im Leben des einzelnen gewinnt aber oft die scheinbare Macht des Zufalls, ein plötzlich und unerwartet eintretendes Ereignis, mit seinen tiefgreifenden Folgen eine wahrhaft dämonische Bedeutung. Es verursacht neue überraschende Wendungen und Verknüpfungen von Persönlichkeiten und Verhältnissen, bringt neue Bezüge und Gesichtspunkte, drängt schwankende Richtungen und Stimmungen zu klarer Entscheidung und löst dadurch Irrungen und Verwicklungen nicht selten in einer Weise, die man früher für unmöglich gehalten und hintendrein doch als die einzig mögliche und vernünftige anerkennen muß. Die Novelle liebt es vorzugsweise solche auffallende Wendungen und Umkehrungen, die man mit der Aristotelischen Peripatie vergleichen kann, zum Vorwurf zu nehmen, ja sie unterscheidet sich, wie Tieck ..... hervorhebt, einzig hierdurch spezifisch von allen anderen Gattungen der Erzählung"'1).

This is by all odds the sharpest, clearest, most definite statement produced by the entire half century of discussion. Its brevity, of course, precludes all treatment of the various side issues, many of them important in their bearing upon essentials; but the chief essentials are stated with a greater clarity and force than any critic in this field, before or since, has been able to muster

1) Herm. Hettner, Die romantische Schule in ihrem inneren Zusammenhange mit Goethe und Schiller, Braunschweig 1850, p. $196 \mathrm{f}$. 
in one brief paragraph. Hettner pretends to no originality whatever; he is attempting nothing more than a restatement of Tieck's theory, omitting all that was non-essential and even false, and testing what is really good in it by Tieck's practice at its best. As a student of literature Hettner was doubtless aquainted with Mundt's definition of the novel, but here there is no hint of it. In any case he has given us in all brevity the second successful differentiation between the two forms, and his definition of the novelle is an improvement on Tieck's both in being less diffuse and in being applicable as well to the species in general as to Tieck's personal conception of the form.

Although literature had returned to aesthetic standards after I850, criticism, at least in the field of the novelle, was slow to follow. Characteristic for the little that appeared in this field between 1850 and 1870 is Gutzkow's discussion in 1868 of the terms roman, novelle and erzählung: ,Roman nennt man die Entwicklung von Menschenschicksalen durch Bedingungen universeller Natur. Solche Bedingungen sind die Geschichte, die Sitten eines Landes, die Sitten einer Zeit, die Stimmungen einer Zeit, die Voraussetzungen der Religion, der Philosophie, der Kunst oder eines ganzen Standes, einer Familie. Die Novelle ist die Entwicklung von Menschenschicksalen durch Bedingungen partikulärer Natur. Hier steht der Geschichte die Chronik gegenüber, den Sitten des Landes die Sitten eines Ortes, den Sitten einer Zeit einzelne Moden, den Stimmungen einer Zeit eine akute Krankheit derselben, den Voraussetzungen der allgemeinen Wissenschaften irgend etwas Besonderes an ihnen, z. B. an dem Gelehrten- oder Künstlerleben. Die Novelle beruht, was das Sckicksal und die Führung unseres Erdenlebens anlangt, auf dem Zufall. Die Laune des Zufalls ist ihre wesentliche Triebfeder und, mechanisch gesprochen, ihre Unruhe. Es kann nur Kunstromane geben, es gibt Künstlernovellen. Es gibt Sittenromane, aber es gibt nur Dorfnovellen. Die einfache ,Erzählung', um auch diese dritte Gattung zu erwähnen, ist die Entwicklung von Menschenschicksalen durch die Bedingungen ihrer selbst. Sie schließt die Nebenbedingung, irgend etwas Universelles oder noch etwas Partikuläres besonders zur Anschauung zu bringen, aus. Sie beruht auf ihren eigenen Voraussetzungen und nähert sich deshalb am meisten dem Drama. Aus 
Romanen und Novellen ein Drama zu schaffen, ist gefährlich und beinahe unmöglich. Die Erzählung ist aber schon an und für sich selbst ein objektiv berichtetes Drama. Der Roman und die Novelle streben höher als die Erzählung, denn sie lassen keine andere als eine künstlerische Leistung zu, während die Erzählung nur die Merkmale der Glaubwürdigkeit und Folgerichtigkeit an sich zu tragen hat. Vorzugsweise die schwierigste Form ist die Novelle. Da in ihr der Zufall nicht blind walten darf, sondern nur das als Zufall den beteiligten handelnden Personen zu erscheinen hat, was im höheren Sinne doch Verhängnis ist, so kann ihre Aufgabe nur durch Humor gelöst werden, diese höchste Gabe des dichterischen Schaffens, die selbst bedeutenden Dichtern nur spärlich verliehen war" $\left.^{\prime \prime}\right)$.

Such a jumble of sense and nonsense as this would not be worth quoting except for the startling contrast it affords to Heyse's admirably sane and keen sense for the definite boundaries separating the different genres. Nothing could bring before us more clearly the entirely different standards of the two generations, here represented by two poets who were about equally prominent in the literary movements with which they were associated, and whose best work lay in closely related fields, Gutzkow's in the novel, Heyse's in the novelle.

\section{Heyse's Theory of the Novelle: 1871-1912.}

When in I87I Paul Heyse and Hermann Kurz began the publication of their Deutscher Novellenschat ${ }^{2}$ ) they found it necessary to establish a norm by which to explain and justify their selections for the anthology, and the task naturally fell to Heyse. Heyse's fame as a poet stood just then nearly at its zenith; in Germany he was undisputed master in the field of the novelle, and he had enjoyed an enormous popularity as a writer of novellen ever since the immediate success of his L'Arrabiata on its appearance in 1853 . Even at that time Heyse had already attained considerable clarity as to the

1) Karl Gutzkow, Vom Baume der Erkenntnis. Denksprüche, 2. Aufl. Stuttgart 1869, 209 ff. (1. Aufl. 1868).

2) Deutscher Novellenschats hrsg. von Paul Heyse und Herm. Kurz, 24 Bde., München o. J. (1871-76). 
laws governing the technic of the genre ${ }^{\mathbf{1}}$ ), but his first general statement and definition appeared in $187 \mathrm{I}$ as the introduction to the first volume of the Novellenschatz.

Like most critics who precede him, he approaches the problem from the historical side. After its origin in Italy in the $13^{\text {th }}$ century the novelle had been raised to a high artistic level by Boccaccio and had then been ,,künstlerisch erweitert und seelisch vertieft" by Cervantes, but not until much later did the form take root on German soil. Among the brief prose tales in German literature before the beginning of the Igth century only those in Goethe's Unterhaltungenn (I795) can lay any claim to the title novelle: „Nicht früher nämlich als zu Ende des vorigen Jahrhunderts und durch Goethe wurde dieselbe in unsere Dichtung eingeführt. Es ist von Gewicht, daß der Begründer der deutschen Novelle eben damals, als er in den Unterhaltungen der Ausgewanderten ein modernes Dekameron anzulegen beabsichtigte, mit jenen spanischen Musternovellen vertraut wurde, in welchen

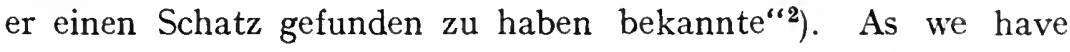
seen, there is no ground for this assumption that Goethe knew the Novelas exemplares soon enough to have been influenced by Cervantes in the composition of the novellen in the Unterhaltungen, $\left.{ }^{3}\right)$, and yet both the Prokurator and Ferdinand are "exemplary" even in the sense in which Cervantes uses the term. In any event he was rejoiced to find in Cervantes a kindred spirit, and whether with or without such influence Goethe's title to the distinction of being the "founder of the German novelle" has never been disputed.

Not until long after their publication in I8II were Kleist's novellen rescued from undeserved oblivion, and so the mantle of Goethe fell upon Tieck and the real rise of the form in Germany as an increasingly important branch of literature dates from the appearance of Tieck's first novellen in 1822. Heyse finds Tieck's immense vogue among his contemporaries wellnigh incomprehensible, yet he is by no means blind to the older poet's

$\left.{ }^{1}\right)$ Cf. Heyse's autobiography, fugenderinnerungen und Bekenntnisse, 5. Aufl. $(=$ 2. Ausg.), Stuttgart und Berlin I9I2, II, 67 .

2) Novellenschatz, I, p. VII.

3) See above, p. 27 and note 3 . 
important services to the novelle: ,So viel man aber auch mit allem Recht an ihnen [Tiecks Novellen] aussetzen mag: zu ihrer Zeit waren sie eine Tat; ein offener Bruch mit der falschen Kunst, zwei für sich gleichberechtigte Erzählungsgebiete, das Wunderbare und das Natürliche, das Märchen und die Wirklichkeit, zu beiderseitigem Schaden miteinander zu vermengen. Goethes recht ausdrücklich ,Novelle' überschriebene phantastisch-mystische Erzählung ..... schien diesen Mißbrauch zu rechtfertigen, und Tieck selbst hatte ihm, besonders in einigen Erzählungen seines Phantasus, nur allzu sehr gehuldigt. Jetzt führte er die Novelle aus der Zaubernacht und Dämmerung der Romantik in das helle Tageslicht heraus"'1).

Tieck's great service to the novelle lay, as Heyse says, in his bringing the form back from its Romantic wanderings in the empyrean to the solid ground of reality, and here Tieck is the forerunner of the Young Germans to whom we are wont to ascribe the beginnings of modern realism in Igth century German literature. A point that Heyse does not touch upon is Tieck's skillful translation of Romantic "wonder" into the marvellous, or at least extraordinary, occurrences of everyday life. This phase of Tieck's work marks the transition from romanticism to realism, and it is besides a return to that basic element in the novelle which demands novelty, not in the realm of the supernatural, but strictly within the limits of reality. Heyse was acquainted both with Tieck's definition of 1829 and with his introduction to Bülow's Novellenbuch published five years later ${ }^{2}$ ), but he enters into no discussion of Tieck's theory of the novelle, which centers about the idea of the "turning point", except in so far as it touches upon the return to reality: ,Denn nicht viele Jahrzehnte sind zu zählen, seit die Novelle das von Tieck gegebene Versprechen, daß sie auch im Wunderbaren stets natürlich sein werde, in gutem Ernste zu erfüllen begann. Damit dies geschehen konnte, mußte erst der soziale und künstlerische Geist im allgemeinen die große Wandlung erfahren, die mit den

1) Novellenschatz, loc. cit. VIII.

2) loc. cit. VIII f.: „Er selbst hat Boccaz, Cervantes und Goethe als seine Muster und Vorbilder in dieser Gattung bezeichnet [1829], und zumal mit Begeisterung spricht er von den ,leuchtenden" Novellen des Cervantes" [1834]. 
letzten Regungen der Romantik entschieden brach, und die wir mit dem landläufigen Schulwort die Wendung zum Realismus nennen wollen"1). Only an age in which politics and philosophy returned to the firm basis of actuality, in which historical method was founded on investigation of the sources, and that of the natural sciences upon actual experiment, - only such an age could favor a poetic form, in der die Begebenheit, das Ereignis, der einzelne Fall so vielfach ohne alle höheren Ansprüche auf absoluten sittlichen und dichterischen Wert zu ihrem Rechte kommen"2).

The right of the novelle to treat its main theme as an isolated case without involving human standards in general, and moral standards in particular, Heyse has defended repeatedly and energetically. It was an essential part of his theory of the species, a fact which many of his hostile critics in the eighties and early nineties quite failed to $\left.\operatorname{grasp}^{3}\right)$. By nature the novelle is the most hospitable of literary forms to the singular and exceptional personality or event in real life, and the psychological treatment of the "case" in question may rightly differ from that of the novel whose sphere is so different. This phase of "inner" form is one in which Heyse's theory and practice were ever remarkably definite and consistent, but in this instance he merely touches upon the idea in passing and returns at once to matters of "outer" form.

The rise of journalism in Germany, which was approximately synchronous with the beginnigs of the Young German movement, had both a good and a bad effect on the development of the novelle. Newspapers and periodicals opened their columns readily to all forms of prose fiction and brought authors into immediate touch with a larger public than ever before, but they also encouraged mediocrity, and serial publication was fraught with grave dangers for the novelle in particular: „Die abgerissene Form des Erscheinens nämlich entwöhnte die Leser bald genug, auch eine Novelle als ein kleines Kunstwerk, ein abge-

1) loc. cit. IX.

2) loc. cit. $X$.

3) Cf., e.g., Otto Kraus, Paul Heyses Novellen und Romane, Frankfurt a. M. 1888, which in the last analysis is an attack on Heyse's low moral standards and lack of psychological penetration. Hebbel's position on this question is essentially: the same as Heyse's; see above, p. 60. 
rundetes Ganzes zu genießen und selbst an diese bescheidenste dichterische Form die Ansprüche der möglichsten Vollendung zu machen"1). Thus the attention of the author was distracted from essentials in the composition and form of the whole, and his endeavor centered more and more upon so constructing each separate segment as to whet the reader's appetite for the next instalment. The result was that the novelle was largely forced into the background by various bastard forms of little literary merit, such as "Reisenovellen", „Feuilletonphantasieen“", "Capriccios" and the like. In the preface to her Jeanne (1852), a part of which Heyse quotes, George Sand has complained of a similar state of things in France, and there can be little doubt that the relative brevity and compactness of the American shortstory is the result of a compromise between the author's demand (first voiced by Poe) for "unity of impression" on the one hand and the exigencies of periodical publication on the other. Here the monthly magazine, not the daily paper, has been a determining factor, and so the evils of serial publication have been avoided; but practically all short-stories make their first appearance in the magazines, extreme compactness of structure is hence the norm, and the "long short-story" (The Man Without a Country, Dr. Jekyl and Mr. Hyde), which most nearly approaches the form of the novelle, is the rare exception and is viewed askance by the critics. The novelle of the present day by no means always makes its first appearance in a periodical, and when it does the author does not scruple to divide it between two numbers if need be. Totality of impression may be lost, but there is a compensating gain in the better motivation and broader psychological treatment of the fuller form.

Turning to the question of content, Heyse, like A. W. Schlegel and Tieck, sets no limit so long as the bounds of reality be not overstepped: „Nil humani a me alienum p u t o . . . . dieser Losung wird die Novelle mit vollster Unumschränktheit treu bleiben müssen . . . . V Von dem einfachen Bericht eines merkwürdigen Ereignisses oder einer sinnreich erfundenen abenteuerlichen Geschichte hat sich die Novelle nach und nach $\mathrm{zu}$ der Form entwickelt, in welcher gerade die tiefsten und wich-

1) Novellenschatz, I, p. XI. 
tigsten sittlichen Fragen zur Sprache kommen, weil in dieser bescheidenen dichterischen Gattung auch der Ausnahmefall, das höchst individuelle und allerpersönlichste Recht im Kampf der Pflichten, seine Geltung findet. Fälle, die sich durch den Eigensinn der Umstände und Charaktere und eine durchaus nicht allgemein gültige Lösung der dramatischen Behandlung entziehen, sittliche Zartheit oder Größe, die zu ihrem Verständnis der sorgfältigsten Einzelzüge bedarf, alles Einzige und Eigenartige, selbst Grillige und bis an die Grenze des Häßlichen sich Verirrende ist von der Novelle dichterisch zu verwerten. Denn es bleibt ihr von ihrem Ursprung her ein gewisses Schutzrecht für das bloß Tatsächliche, das schlechthin Erlebte, und für den oft nicht ganz reinlichen Erdenrest der Wirklichkeit kann sie vollauf entschädigen, teils durch die harmlose Lebendigkeit des Tons, . . . . . teils durch die unerschöpfliche Bedeutsamkeit des Stoffes selbst, da der Mensch auch in seinen Unzulänglichkeiten dem Menschen doch immer das Interessanteste bleibt" ${ }^{\prime 1}$ ).

Here for a second time the rights of the exceptional case to exceptional treatment are asserted, and in this connection a point of dissimilarity between the novelle and the drama receives attention. Heyse evidently feels that the drama demands a solution of the individual problem which is in accord with generally accepted standards, and that dramatic characterization is too obvious in its method to treat successfully certain psychological niceties, which demand the fuller consideration and more detailed treatment characteristic of the method of the modern novelle. It is interesting to note in passing that Tieck, a common source of inspiration to both Mundt and Heyse, is blind to all similarity between the novelle and the drama, and that Goethe, whom Heyse knew so intimately, nowhere points to any relationship between the two forms. Characteristic for Heyse is the self-imposed halt before ,alles ..... bis an die Grenze des Häßlichen sich Verirrende". His .conflict later on with the Naturalists was largely brought. about by his consistent refusal to admit the ugly to a place within the realm of literature. To our modern sense Heyse, like most other poets of his generation, was indeed over-selective. $\mathrm{He}$ and the others reacted a little too strongly 1) loc. cit. XIV f. 
against the Young German lack of a sense of selection, just as Young Germany and the Naturalists went too far in the attempt to include absolutely all phases of life within the scope of literature. Heyse with all his sympathy for ,,alles Einzige und Eigenartige, selbst Grillige" was utterly lacking in that appreciation for la beauté du laid upon which we of today are inclined rather to pride ourselves.

However minute and delicate may be the treatment demanded by many of our modern psychological problems, the story teller must not allow himself to be led astray into a virtuosity which confuses the means with the end: „,.... der Erzähler dürfte nie vergessen, daß, wie bloße Farbeneffekte noch kein Bild machen, ein noch so geistreiches Spiel mit zerflatternden Motiven keine $\mathrm{Ges} \mathrm{ch}$ i cht e ergibt, die unserer Phantasie eingegraben bleibt, und daß auch in diesem Gebiet, groß sein heißt, nicht ohne großen Gegenstand sich regen"1).

This thought that the means must all serve one definite end brings Heyse to his distinction between the novel and the novelle: „Denn wie sehr auch die kleinste Form großer Wirkungen fähig sei, beweist . . . . gerade die Novelle, die im Gegensatz zum Roman den Eindruck eben so verdichtet, auf einen Punkt sammelt und dadurch zur höchsten Gewalt zu steigern vermag, wie es der Ballade, dem Epos gegenüber, vergönnt ist, mit einem raschen Schlage uns das innerste Herz zu treffen. Es kann hier nicht unsere Aufgabe sein, das Kapitel der Ästhetik über Roman und Novelle zu schreiben ..... . So viel aber muB doch ... . gesagt werden, daß wir allerdings den Unterschied beider Gattungen nicht in das Längenmaß setzen, wonach ein Roman eine mehrbändige Novelle, eine Novelle ein kleiner Roman wäre. Da lang und kurz relative Begriffe sind, . . . . . so muB, wenn es sich um mehr als Namen handeln soll, schon im Thema, im Problem, im unentwickelten Keim etwas liegen, das mit Notwendigkeit zu der einen oder anderen Form hindrängt. Und dies scheint, wenn man auf das Wesentliche sieht, in folgendem $\mathrm{zu}$ beruhen.

Wenn der Roman ein Kultur- und Gesellschaftsbild im Großen, ein Weltbild im Kleinen entfaltet, bei dem es auf ein

1) loc. cit. XVI. 
gruppenweises Ineinandergreifen oder ein konzentrisches Sichumschlingen verschiedener Lebenskreise recht eigentlich abgesehen ist, so hat die Novelle in einem e in zig e n Kreise einen e i nz e ln e n Konflikt, eine sittliche oder Schicksals-Idee oder ein entschieden abgegrenztes Charakterbild darzustellen und die Beziehungen der darin handelnden Menschen zu dem großen Ganzen des Weltlebens nur in andeutender Abbreviatur durchschimmern zu lassen. Die Ge s chich te, nicht die Zustände, das E r e ig $\mathrm{n}$ is, nicht die sich in ihm spiegelnde Weltanschauung, sind hier die Hauptsache; denn selbst der tiefste ideelle Gehalt des einzelnen Falles wird wegen seiner Einseitigkeit und Abgetrenntheit - der Isolierung des Experiments, wie die Naturforscher sagen - nur einen relativen Wert behalten, während es in der Breite des Romans möglich wird, eine Lebens- und Gewissensfrage der Menschheit erschöpfend von allen Seiten zu beleuchten"'1).

We have seen that neither Goethe nor Tieck had attempted any formal distinction between these two species; that A. W. Schlegel, with whose work Heyse apparently was not acquainted, had felt an essential difference and had at least discarded the criterion of bulk, but had not succeeded in accomplishing an altogether satisfactory differentiation; that Mundt was the first to arrive at a really satisfactory distinction; and that Hettner had stated the difference briefly but clearly. It is entirely possible, even probable, that Heyse was acquainted with the statements of both Mundt and Hettner, - there is even a faint echo of Hettner's "Totalität eines ganzen Welt- und Zeitbildes" in the paragraph quoted above. And yet Heyse's ,Kultur- und Gesellschaftsbild im Großen, ein Weltbild im Kleinen“ and his ,,ein gruppenweises Ineinandergreifen oder ein konzentrisches Sichumschlingen verschiedener Lebenskreise" draw a much sharper and clearer line of definition about the novel than the work of any predecessor of his. had succeeded in doing. For the novelle the great distinctive characteristic is intense concentration upon the single and singular central theme in all its "onesidedness and isolation", - and here for the third time the right of such a theme to a treatment. allowing disregard of broad general standards is given a prominent

${ }^{1)}$ loc. cit. XVI ff. 
place. A. W. Schlegel's statement, „In der Novelle muß etwas geschehen “1), is put much better by Heyse: „Die G e s c h i c h t e , nicht die Zustände, das E re i g n is, nicht die sich in ihm spiegelnde Weltanschauung, sind hier die Hauptsache".

What importance Heyse attaches to "isolating" the problem in the novelle is evident in his attitude toward Goethe's Wahlverwandtschaften. For Mundt it had been distinctly a novelle whose unusual length is due to the complexity of the central theme, while for Heyse it is a transitional form and nearer the novel than the novelle: „Freilich wird es auch hier an Ubergangsformen nicht fehlen. Hat doch unser größter Erzähler in seinen ,Wahlverwandtschaften " ein echt novellistisches Thema mit vollem Recht zum Roman sich auswachsen lassen, indem er das bedeutende Problem in ein reich gegliedertes soziales Leben hineinsetzte, obwohl vier Menschen auf einer wüsten Insel ebensogut in die Lage kommen konnten, die Gewalt dieses Naturgesetzes zu erfahren" 2 ). Since the problem lacks the proper isolation, the form lacks the necessary concentration and the result is neither one thing nor the other. If Heyse had discussed the two longer novellen of Tieck, which Mundt found to be essentially what Tieck called them, the result would in all likelihood have been the same as in the case of the Wahl verwandtschaften.

Excellent as Heyse's definition of the novelle is, with its clear line of demarcation between the sister forms, it would never have attained to its present wide popularity nor gained the hold it has upon all later theorists except for the fact that it can be summed up in two words: silhouette and falcon. One wonders whether Heyse had the value of a good catchword in mind when he penned the following paragraph: „Im allgemeinen aber halten wir auch bei der Auswahl für unsern Novellenschatz an der Regel fest, d e r Novelle den Vorzug zu geben, deren Grundmotiv sich am deutlichsten abrundet und - mehr oder weniger gehaltvoll etwas Eigenartiges, Spezifisches schon in der bloßen Anlage verrät. Eine s t a rke Sil h o u e t t e-um ..... einen Ausdruck der Malersprache zu Hilfe zu nehmen - dürfte dem, was wir

1) See above, p. 35 .

2) Novellenschatz, I, p. XVIII. 
im eigentlichen Sinne Novelle nennen, nicht fehlen, ja wir glauben, die Probe auf die Trefflichkeit eines novellistischen Motivs werde in den meisten Fällen darin bestehen, ob der Versuch gelingt, den Inhalt in wenige Zeilen zusammenzufassen, in der Weise, wie die alten Italiener ihren Novellen kurze Überschriften gaben, die dem Kundigen schon im Keim den spezifischen Wert des Themas verraten"1). By way of illustration Heyse quotes the brief summary prefixed by Boccaccio to the story of the falcon (Decamerone, V, 9), - a story, by the way, which Goethe thought of dramatizing and which Tennyson among a score of others actually did dramatize, though with no great success. However, the relation between the novelle and the drama does not concern Heyse here, and he continues: ,..... wer erkennt nicht in diesen wenigen Zeilen alle Elemente einer rührenden und erfreulichen Novelle, in der das Schicksal zweier Menschen durch eine äußere Zufallswendung, die aber die Charaktere tiefer entwickelt, aufs liebenswürdigste sich vollendet? Wer, der diese einfachen Grundzüge einmal überblickt hat, wird die kleine Fabel je wieder vergessen ..... Wir wiederholen es: eine so einfache Form wird sich nicht für jedes Thema unseres vielbrüchigen modernen Kulturlebens finden lassen. Gleichwohl aber könnte es nicht schaden, wenn der Erzähler auch bei dem innerlichsten oder reichsten Stoff sich zuerst fragen wollte, wo ,der Falke' sei, das Spezifische, das diese Geschichte von tausend anderen unterscheidet" $\left.{ }^{\prime 2}\right)$.

Heyse's sharp silhoutte is a conception very similar to Mundt's circle drawn about a given center; behind both conceptions lies the idea of an isolated, well rounded structure built up about a definite central theme. Heyse's "falcon" is essentially identical with Tieck's "turning point", or at least it has the same functions; it is the core which gives significance to the encircling action, it serves to distinguish the novelle from all other literary genves, and it sets the one novelle apart from every other in the mind of the reader. Besides it contains for both poets that element of novelty which is the life blood of the novelle. When Heyse refers to the "falcon" as ,eine äußere Zufallswendung, die

\footnotetext{
1) loc. cit. XIX.

2) loc. cit. $X X$.
} 
aber die Charaktere tiefer entwickelt", we hardly need assume that he thereby refuses to accept Mundt's doctrine of fixed and developing character in the novelle and the novel respectively. This question, like that of the elements which the novelle and the drama have in common, Heyse nowhere so much as mentions. Here he would rather seem to have in mind what Goethe means when, in connection with his Ferdinand, he speaks of the ,Begebenheit, die seinen Charakter ins Licht setzt und in seinem Leben entschiedene Epoche machte", and with reference to which later on in the story he calls especial attention to ,ein sonderbarer Zufall, der ihm eine reizende Gelegenheit gab, dasjenige zu tun, wozu er nur einen dunklen und unentschiedenen Trieb gefühlt hatte"1). That is to say, chance has its place in the novelle, but only when made an organic part of the story, not when introduced arbitrarily, as so often in Tieck's novellen, where it militates against that innate realism which is characteristic of the species. In any event Heyse's expression is ill chosen. It can not be taken literally, for there is no development of character in Boccaccio's Falcon novella.

There is one striking difference between the statements of Tieck and Heyse: Tieck gives the novelle a place in literature not less exalted than that of the drama and the novel, while Heyse refers to it somewhat apologetically as a "modest genre". This difference in attitude is, however, rather apparent than actual. Tieck had claimed this exalted position for the novelle because its mission lies in a field apart. Dealing as it does with exceptional cases, it seeks to soften the harsh contrasts in life, to explain the whims of fate, and to find even in evil a higher compensating truth; ,darum ist dieser Form der Novelle vergönnt, über das gesetzliche $\mathrm{Ma} B$ hinwegzuschreiten und Seltsamkeiten unparteiisch und ohne Bitterkeit darzustellen, die nicht mit dem moralischen Sinn, mit Konvenienz oder Sitte unmittelbar in Harmonie stehen" 2 ). By making this exceptional position of the novelle one of the main tenets of his theory of the species Heyse is following directly in Tieck's footsteps and is virtually accepting Tieck's high standard. Why else should he put his

1) See above, p. 26.

2) See above, p. 38 . 
best critical effort into a definition of this ,,bescheidenste Gattung“" ? One feels in Heyse's adjective that conventional editorial pseudomodesty which has very little to do with the personal attitude and convictions of the writer $\mathbf{1})$.

Except for these two minor slips of an over-facile pen one can not but admire the lucidity of the famous Falcon Theory. Goethe's equally famous epigrammatic definition is so brief that it stands in need of considerable comment. Tieck's definition is very good in part, and in part it is, like his practice, anything but acceptable. Hettner's admirable restatement of Tieck's theory is perhaps as good as any statement of equal brevity could be. Finally the Falcon Theory is as brief as an adequate discussion of the matter permits, and it has this advantage over all the rest, that it can be summed up in two striking catchwords which characterize the form in both its outer and its inner aspect and make an indelible impression on the memory.

In Heyse's earlier critical studies, and here and there in the frame story of a novelle, there are passages which foreshadow many phases of this discussion in the introduction to the Novellenschatz. Heyse's aversion from that realism which goes to the extreme of naturalism makes its appearance long before I87I. In a review of Dingelstedt's poems in 1858 Heyse makes vigorous objection to the poet's frankness in regard to certain of his less attractive personal experiences: „Wo aber die nackte Tatsache anerkannt wird, da beginnt das Reich der Prosa. .... . Wer aber dankt es ihm, wenn er uns sein Bild vorhält ge. rade aus einer Zeit, wo eine geistige Krankheit es entstellt, eine vorübergehende Ưberreizung die Züge abschreckend verhäßlicht

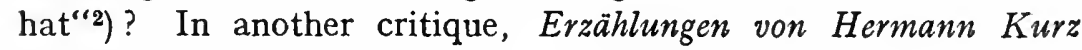
(I858), this hypersensitiveness toward the ugly goes to the

1) Cf. Heyse, Fugenderinnerungen, I, 224: „Auch rechnete er [Graf von Schack] als ein richtiger Platenide Novellen und Romane nicht zur Poesie und sprach geringschätzig von allem, was sich in prosaischer Form hervortat." (Amkg.) ,Wie Wilhelm Jensen, einer der treuesten Jünger und Anhänger Geibels, dazu kommen konnte, auch ihm nachzusagen, da $B$,Prosaschriften für ihn mit der Dichtung nichts gemein' gehabt hätten . . . . ist mir unerklärlich."

2) Gedichte von Franz Dingelstedt, first published in the Literaturblatt zum deutschen Kunstblatt, Sept. I858; reprinted in Fugenderinnerungen II, 22 Iff.; cf. loc. cit. 223. 
extent of praising Kurz for not exhausting the possibilities of an excellent novelle motif: „In der Geschichte von der blassen Apollonia wird das seltsame Bild eines fünfzehnjährigen Mädchens vorgeführt, das vom Dorfe weg als Kindermädchen in die Stadt kommt and dort von so starkem Heimweh ergriffen wird, daß sie, in dem wundersamen dunklen Wahn, nur das Kind, das sie wartet, trenne sie von den Ihrigen, das unschuldige Wesen in einer blinden Aufregung vergiftet. Mit welchem Aufwand tieferschütternder Seelenschau hätte ein Talent wie Otto Ludwig diese Geschichte ausgestattet. Kurz erzählt sie auf zehn Seiten und stellt das Problem nur eben hin. Und freilich tut er wohl daran, und norddeutsche Novellisten sollten sich immerhin bei manchen Stoffen fragen, ob die Anwendung a lle r Kunstmittel für j e de s Motiv ratsam sei, oder nicht vielmehr die Novelle sich ihres alten Vorrechts, seltsame Ereignisse einfach festzuhalten, begebe, wenn sie überall die volle Farbe auftrage, auch wo ein Stoff höchstens in den Konturen für unser Gemüt erträglich bleiben kann"1).

The most definite statement in this connection before the appearance of the Novellenschatz is found in the opening paragraphs of Die Witwe von Pisa (I865), where the poet speaking in propria persona says: „Ich habe nie eine Figur zeichnen können, die nicht irgend etwas Liebenswürdiges gehabt hätte ..... Was mir schon im Leben gleichgültig war, oder gar widerwärtig, warum sollte ich mich in der Poesie damit befassen? Es gibt genug andere, die es vorziehen, das Häßliche zu malen." His interlocutor thereupon objects: „Aber ich habe immer sagen hören, die Poesie solle das Leben wiederspiegeln. Nun denn, das Leben hat doch auch seine Kehrseite. Und zur W a h r he it gehört Licht und Schatten. Glauben Sie nicht, $\mathrm{da} B$ Sie es der Wahrheit schuldig sind, auch von den minder liebenswürdigen Figuren, die zum Beispiel in Italien herumlaufen, Notiz zu nehmen ?" Heyse's reply to this objection rules the ugly out of literature quite as definitely as does the statement of I87I: ,Sobald jch ein Buch über den italienischen Volkscharakter ankündige - gewiB! Aber ich gebe Geschichten. Wenn ich lieber Geschichten schreibe, die mir selbst gefallen, als Schatten-

1) loc. cit. 220. The essay was first published in the Literaturblatt, Aug. 1858. 
risse von der Kehrseite der Natur, wen betrüge ich, als solche, die ihr Interesse dabei finden, sich betrügen zu lassen"1)?

In the frame story to Die Stickerin von Treviso (I868) can be found a forestudy to the later statement that in the novelle the story is above all things of importance: „Der Abstand zwischen der Holzschnittmanier einer alten Städtechronik und der photographischen, stereoskopischen, ausgepinselten Zierlichkeit und Ausführlichkeit so einer modernen Novelle ist auch gar zu himmelweit. Dort alles noch Rohstoff ..... das Material bunt übereinander geschichtet, da $B$ nur der Kenner oder Liebhaber sich das Seinige daraus zusammensuchen mag. Und in unserer kunstgewandten modernen Zeit alles so glatt und blank, so bewußt und bedacht, so in lauter Stil und Form verwandelt, $\mathrm{da} B$ der Gegenstand einem oft ganz entschwindet, das Was vor dem Wie vergessen wird und wir vor lauter psychologischen Finessen des Erzählers uns fast nicht mehr um die Menschen bekümmern, an denen er seine Künste entfaltet. Ich dagegen stehe noch auf dem veralteten Standpunkt, daß mir in jeder Geschichte die G e schichte selbst die Hauptsache ist" ${ }^{\prime \prime 2}$ ).

Heyse's attitude toward the role that chance should be allowed to play in the novelle is not altogether clear in his discussion of Boccaccio's Falcon novella, as we have seen, but two passages from critical essays of an earlier date throw some light on this subject. From the essay on Eduard Mörike (I854) it becomes evident that Heyse considers blind chance an enemy to realism and hence quite as much out of place in the novelle as in the novel (here specifically Maler Nolten): „Lassen wir auch einen Augenblick die unwahrscheinliche Erfindung . . . . dahingestellt, so bleibt es eine poetische Sünde, Menschen, die das gesundeste Wachstum gezeigt, sich nach allen Seiten zu unserer Freude entwickelt, aus Irrsalen aufgerafft, aus Entfremdungen sich heftig (?) und für immer wiedergefunden haben, durch ein plötzliches, unbegreiflich hartes Wundergeschick hinraffen zu lassen, während wir sie im Begriff glaubten, die Frucht so vieler bitteren Erfahrungen zu genießen. Was der Dichter ge$\tan$ hat, jenen herben SchluB von Anfang an vorzubereiten, ist

1) Paul Heyse, Novellen, wohlfeile Ausg., Stuttgart Igo4 ff., I, 23 I f.

$\left.{ }^{2}\right)$ op. cit. II, $65 \mathrm{f}$. 
teils sehr äußerliche (oft mangelhaft motivierte) Zutat, teils im Verlauf der Geschichte jedesmal von den Menschen selbst so herzhaft überwunden worden, $\mathrm{da} B$ nun die neue Häufung und Sammlung nichtiger Momente am Ende teils ungerecht, teils unwahr erscheint" 1 ). In Hebbel's novellen also Heyse finds that blind chance is given too great scope: „Wir erinnern an [Hebbels] . . . . Novellen, in denen eine trostlose Welt- und Kunstanschauung das Häßliche mit Bewußtsein in allen Lebensverhältnissen aufspürte, und im Gegensatz zu der wahren Aufgabe der Poesie, die Widersprüche der Welt in verklärter Gestalt zu versöhnen, es sich angelegen sein ließ, die Ironie eines blind zerstörenden Zufalls als die oberste Macht in den irdischen Dingen hinzustellen"2).

It seems strange that Heyse should never have returned to this matter of "Zufall" which is so important in its bearing upon what Tieck had styled the turning point, but which must ever yield to the demand for verisimilitude. Tieck, for one, was often guilty of disregarding this demand and letting mere chance play too great a part in his novellen, but Heyse's comment, in the introduction to the Novellenschatz, upon Tieck's failings is couched only in very general terms: "Der Meister selbst erlitt große Rückfälle; und was von der Natur gesagt ist, daß sie mit keiner Gewalt ganz auszutreiben sei, das läßt sich zu Zeiten auch von der Unnatur sagen. Die falsche Romantik war in der alten Gestalt überwunden; aber sie wechselte proteïsch ihre Formen und Farben, und noch eine geraume Zeit sollte es dauern, bis ihr wunderlicher Rocken bis auf den letzten Faden abgesponnen war'(3). All this might well be applied to Tieck's attitude toward chance, but Heyse does not specify.

In later life Heyse returned once again to his theory of the novelle. When in Igoo he published his autobiography ${ }^{4}$,

1) Fugenderinnerungen, II, I16. First in the Literaturblatt, Jan. I854.

$\left.{ }^{2}\right)$ loc. cit. 182, from the essay on Fr. Hebbel als Lyriker. First in the Literaturblatt, Jan, 1858 .

3) Novellenschatz, I, p. IX.

4) Paul Heyse, fugenderinnerungen und Bekenntnisse, Berlin 1900. The last ( 5 th) edition in two volumes ,neu durchgesehen und stark vermehrt", Berlin and Stuutgart I912, shows no important change in the chapter, Meine Novellistik, and so I quote from the last edition throughout. 
he included at the end of the volume under the general heading, Aus der Werkstatt, a chapter entitled Meine Novellistik, which, together with matters of his own personal technic, contains a restatement and amplification of the Falcon Theory. Since his first beginnings as a writer of novellen Heyse had remained remarkably consistent in his practice for nearly half a century, and so as a matter of course he now had no essential change to make in his theory. There are, however, interesting minor developments such as, for instance, the transfer of emphasis from Goethe to Tieck in the beginnings of the novelle in Germany: „Goethe selbst, der größte aller Erzähler, hạt zur eigentlichen Novelle nur gelegentlich einen Anlauf genommen, der oft vor dem letzten Ziele stecken blieb und sich in einen größeren Rahmen verlor, wie im Mann von fünfzig Jahren, derPilgernden Törin, den Wunderlichen $\mathrm{Nach}$ b a rskindern ..... und was er selbst schon durch den Titel als eigentliche, Novelle' wollte angesehen wissen, ..... läßt vermuten, daß ihm für den Gattungscharakter dieser Dichtungsart das Wunderbare, Unerhörte, wenigstens Einzigartige maßgebend war.

Was vor und neben ihm Wieland an kürzeren Erzählungen geschaffen hat, hält sich auf dem Grenzgebiet zwischen Roman und moralisierender Skizze und steht den Voltaireschen Romanen näher als deutschen Vorbildern. Erst Tieck setzte das von Goethe Angebahnte erfolgreich fort, durch die Hinneigung der Romantik zu den romanischen Literaturen auf das Vorbild des Boccaccio und Cervantes geführt, deren engere Formen und fast auschließend erotische Themata er selbständig erweiterte, so da $B$ er in der Tat als der Schöpfer der modernen Novelle anzusehen ist. Wir können sagen, daß durch ihn und seine Nachfolger .... dieses ganze Kunstgebiet, die novellistische Provinz, zu dem weiten Reiche unserer Klassiker hinzuerobert worden ist" ${ }^{1}$ ).

Here Heyse deals more definitely with Tieck's shortcomings than formerly: „Tieck selbst aber erscheint in seinen Novellen durchaus nicht immer musterhaft. Da ihm die naive Vollkraft der Phantasie, die den großen Dichter macht, gebrach, die be-

1) op. cit. II, $67 \mathrm{f}$. 
rüchtigte romantische ,Ironie' sich oft als Spielverderberin einmischte ....., gelang es ihm selten, auch eine glückliche Erfindung rein durchzuführen, ohne durch störende Zutaten, witzige oder lehrhafte Gespräche, die den Personen äußerlich angeheftet sind und nicht aus ihrem Charakter entspringen, oder durch willkürliche Führung der Fabel den vollen Eindruck zu schädigen “1). Tieck's "arbitrary structure of the plot" is often the result of introducing chance as an inorganic element, but Heyse does not call attention to the fact.

Heyse would seem by now to have come definitely to the conclusion that his title to fame will rest almost exclusively on his work in the novelle; at any rate the species in its modern development is no longer referred to as „eine bescheidenste Gattung": „Seitdem aber haben wir uns gewöhnt, an die Novelle höhere Forderungen zu stellen, als $\mathrm{da} B$ sie ein müßiges Unterhaltungsbedürfnis befriedige und durch eine Reihe bunter Abenteuer uns ergötze ..... Denn von einer Novelle, der wir einen künstlerischen Wert zuerkennen, verlangen wir wie von jeder dichterischen Schöpfung, daß sie uns ein bedeutsames Menschenschicksal, einen seelischen, geistigen oder sittlichen Konflikt vorführe, uns durch einen nicht alltäglichen Vorgang eine neue Seite der Menschennatur offenbare. Daß dieser Fall in kleinem Rahmen energisch abgegrenzt ist, wie der Chemiker die Wirkung gewisser Elemente, ihren Kampf und das endliche Ergebnis ,isolieren' muß, um ein Naturgesetz zur Anschauung zu bringen, macht den eigenartigen Reiz dieser Kunstform aus, im Gegensatz zu dem weiteren Horizont und den mannigfaltigen Charakterproblemen, die der Roman vor uns ausbreitet. Je gehaltvoller die Aufgabe ist, je tiefere Probleme in dieser äußeren Beschränkung gelöst werden, desto ergreifender und nachhaltiger wird die Wirkung sein, desto wichtiger aber die Sorge des Dichters, keinen störenden Zug in das kleine Bild hineinzubringen" 2 ).

Here the former idea of isolation and entire concentration upon the one central theme receives added emphasis, and the psychological element comes rather more decidedly into the fore-

1) loc. cit. 68 .

2) loc. cit. $68 \mathrm{f}$. 
ground, quite in accord with the development of the species in the last quarter of the Igth century. As the great masters of the form in Germany Heyse names ,,vor allen Gottfried Keller und in seinen letzten Novellen Theodor Storm"'). In general however, he finds his countrymen lacking, when compared with their, French and Russian neighbors, in that "artistic delicacy of touch which is indispensable for the mastery of this peculiar genre", though in other respects they possess as story tellers many qualities which their neighbors might well envy them. „Dagegen sehen wir häufig einen dankbaren Stoff entweder durch Überladung mit Beiwerk, oder durch Ungeschick in der Komposition, oder durch Häufung heterogener Motive seine Wirkung verlieren, so daß es nicht überflüssig scheint, gewisse Grundgesetze der Gattung in Erinnerung zu bringen, ohne deren Kenntnis so manches liebenswürdige oder tiefsinnige Talent stets ins Blaue hinein fabulieren wird ..... Daß es auch für die Novelle eine Technik gebe, die aus einem fruchtbaren Motiv die Handlung so folgerichtig geschlossen entwickeln lehre, wie der junge Musiker durch seinen Meister in der Komposition dazu gelangt, ein Thema von wenigen Takten zu einem Sonaten- oder Symphoniesatz auszubilden, davon haben viele Novellisten so einen Begriff, während das Publikum vollends die dichterische Produktion überhaupt als eine Gabe Gottes betrachtet, die dem Talent in ,Weihestunden' durch In-

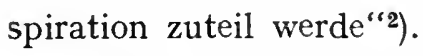

With all due gratitude for the "inspirations" of his own personal experience, Heyse finds them as good as worthless without the foundation afforded by sound technical principles together with a clear conception of the theory of the form. A first requisite is the knowledge of what constitutes a fruitful novelle motif, and here the conception of the sharply defined silhouette again

1) loc. cit. 69. In an early critical essay on Theodor Storm (op. cit. II, I 32 ff.; first in the Literaturblatt, Dec. 28, I854), which dealt with Storm's first novellen, Heyse's attitude had been on the whole rather cool: „Das Außerliche wird bei Storm so innerlich, daß das Innerliche, wenn es sich dann äußert, seinen Vorrang vor jenem einbüßt." (loc. cit. I 34.) His objection at that time was essentially that the lyric element was too strong in Storm to permit the development of a healthy realism. Later his admiration grew with Storm's increasing tendency toward realism.

2) loc. cit. $69 \mathrm{f}$. 
finds application: „Was zunächst die Qualität des Stoffes betrifft, der als spezifisch novellistisch betrachtet werden kann, will ich nur an das erinnern, was ich in der Einleitung zum deutschen Novellenschatz geäußert habe, und was seitdem vielfach als meine ,Falkentheorie" zitiert worden ist: da $B$ man sich fragen müsse, ob die zu erzählende kleine Geschichte eine starke, deutliche Silh o u e $t$ t e habe, deren Umriß, in wenigen Worten vorgetragen, schon einen charakteristischen Eindruck mache, wie der Inhalt jener Geschichte des Decamerone vom ,Falken' in fünf Zeilen berichtet sich dem Gedächtnis tief einprägt" ${ }^{1}$ ). A different sort of story surely has its place in literature, - a well delineated situation, a character sketch, for example; and in exceptional cases even an idyllic situation may be staged with such charm that at the moment we forget all sterner demands for dramatic development of the theme. „Im übrigen werden wir starke Willens- oder Charakterkonflikte nach wie vor vom Drama vorgeführt verlangen, wie von einer echten und gerechten Novelle ein seelisches oder geistiges Problem in einem kräftig begrenzten Fall zum Austrag gebracht werden soll'“2).

Here Heyse neglects the opportunity to discuss the relationship existing between the two forms, though, as we shall see presently, he knew Spielhagen's critical work well and can not fail to have seen how important this relationship is for his brother poet's theory of the novelle. Apparently he wishes to confine himself strictly to the briefer epic forms, for in what immediately follows he goes on to show why the anecdote of the fisherman's son in Goethe's Wanderjahre is not a novelle for all its poetic charm: ,Welch ein Unterschied zwischen einem solchen $\mathrm{F}$ a 11 und einem bloßen $\mathrm{V}$ or $\mathrm{f}$ a $1 \mathrm{l}$ ist, erkennt man leicht, wenn man die kleine Geschichte betrachtet, die im elften Kapitel des zweiten Buchs der Wanderjahre erzählt wird .... . Das novellistisch Unzulängliche, mehr lyrisch Gestimmte des Themas, das in dem bloßen Kontrast der höchsten Wonne und des tiefsten Schmerzes besteht, ist durch die hohe Kunst der Darstellung allerdings ,Ereignis“ auch im künstlerischen Sinne geworden. Da aber aus dem äußeren Geschehnis nichts erfolgt, was eine

1) loc. cit. $71 \mathrm{f}$.

$\left.{ }^{2}\right)$ loc. cit. 72 . 
bedeutungsvoll fortwirkende innere Entwicklung und äußere Handlung einleitete, wird man diese ergreifende Anekdote nur soweit zu den Novellen rechnen können, wie noch viel geringere faits divers im Decamerone mit diesem Namen benannt worden sind"'1).

Heyse then discusses a question of technic, which, however, has direct bearing on his theory. Having found a suitable theme the writer must so treat it as to exhaust all its potentialities, particularly on the psychological side. The result will vary with the temperament and experience of the author, and yet it may be said in general that each fruitful theme is capable of really 'successful development only in one general direction. By way of illustration Heyse draws upon his own experience. As a beginner he had come upon the following theme in a history of literature: „Ein französischer Trouvère, Luco de Grimauld, tötete sich selbst, da ein Mädchen, das er nicht liebte, ihm ein Aphrodisiakum in großer Dosis beigebracht hatte, um ihn für sich zu gewinnen." After a first unsatisfactory attempt in verse form, the poet's riper experience enabled him to grasp all the potentialities of the theme and the result was one of the best of his earlier novellen, Das Mädchen von Treppi (I855). „Wer nun begriffen hat, da $B$ bei der Komposition, novellistischer so gut wie dramatischer, nicht auf ein Zusammensetzen und Ordnen von außen her ankommt, sondern auf ein Entwickeln von innen heraus, wird es sich angelegen sein lassen, bei dem ersten Erfinden so $\mathrm{zu}$ verfahren, daß der Eigenwert des Stoffes, sein spezifischer Gehalt, seine Idee möglichst rein und erschöpfend in dem kleinen künstlerischen Gebilde zur Anschauung komme"

This is the last instance of any comparison of the novelle with the drama. As early as 1858 , in the article on Hermann Kurz, Heyse had called attention to the fact that the North German novelle was mainly dramatic both in conception and in composition, while in South Germany the tendency was more toward the epic depiction of events and social conditions ${ }^{3}$ ), and he says later (I900) of Geibel: „Aber so wie ihm jedes novellistische

1) loc. cit. $72 \mathrm{f}$.

2) loc. cit. 77 .

3) loc. cit. $218 \mathrm{f}$. 
Talent fehlte, stand er auch der Aufgabe des Dramatikers, äußere Umstände zum Hebel innerer Vorgänge zu gestalten, unbehilflich und unlustig gegenüber"1). A possible explanation of Heyse's avoidance of an explicit comparison is hinted at in his discussion of his own work in the drama: „Den Vorwurf freilich habe ich bei vielen meiner Stücke zu hören bekommen, sie seien $\mathrm{zu}$,novellistisch' geartet. Eine nähere Erklärung aber, was darunter zu verstehen sei, sind mir meine Rezensenten schuldig geblieben. Die Sache war ja auch selbstverständlich: da ich als Novellist geschätzt wurde, konnte ich den Novellisten auch auf dem Theater nicht verleugnen" ${ }^{\text {"2) }}$.

As to the manner in which a story may best be told, Heyse's position is that of Goethe, in the Unterhaltungen, and the Schlegels, when they speak of the cultivated story teller in polite society: „Als das Naturgemäßeste ist es mir stets erschienen, was man erzählen will, so vorzutragen, wie man es angeregten und verstehenden Hörern mitteilen würde, die einem in Person gegenübersäßen. Niemand wird es dann einfallen, seine Rede mit rhetorischem Schmuck, sentimentalen Exkursen oder weitläufigen Landschaftsmalereien und Wetterbetrachtungen zu überladen ..... " $\left.{ }^{3}\right)$. This is all of a piece with the demand for that concentration upon the central theme, which should be a point of focus for every element in the structure of the story. For the same reason lengthy descriptions of the personal appearance of the characters are to be avoided: „Es wird darauf ankommen, den Leser in eine Stimmung zu bringen, in der wenige charakteristische Züge ihm genügen, um mit eigener malerischer Phantasie sich das Bild zu vervollständigen. Diese Erregung des inneren plastischen Sinns ist überhaupt für den Erzähler das Wichtigste. Ist er darin ein Meister, so kann er sich alle möglichen Palettenkünste sparen ....." (4). As a case in point Heyse recalls Philine in Goethe's Lehrjahre of whom we learn only that she had beautiful hair, and yet in the course of the story the reader's imagination has been so stimulated that he feels no lack of descriptive detail.
1) op. cit. I, 7 I.
2) op. cit. II, 90 .
3) loc. cit. 82 .
4) loc. cit. $80 \mathrm{f}$. 
Most characteristic of the novelle is its great objectivity. Even such a high priest of subjectivity as Friedrich Schlegel here permits the author only such subjectivity as limits itself to his choice of subject. But Heyse takes issue with Spielhagen's ,strenge Forderung . . . . . sich durchaus hinter seiner Handlung und ihren Figuren verborgen zu halten, mit einer Reflexion oder Gefühlsäußerung sich niemals einzumischen und den Leser dadurch daran zu erinnern, daß es ein so und so gearteter Mensch ist, der ihm die Geschichte vorträgt. Es kommt auch hier nur auf den richtigen Takt und das $\mathrm{MaB}$ in der subjektiven Anteilnahme an." The dramatist is governed in this respect by a law which is not binding for the epic poet. But how temperate Heyse is in the matter of epic subjectivity is evident from the example which he cites to prove his point: „Wen hätte nicht die berühmte Stelle in den Wahlverwandtschaften erschüttert, wo Goethe, nachdem er geschildert hat, wie Eduard und Ottilie in zwei benachbarten Zimmern getrennt übernachten, das Kapitel mit den Worten beschließt: ,Jammervoller brachten kaum jemals in solcher Nähe Liebende eine Nacht zu“"'1).

Heyse closes this chapter with a discussion of the merits of the verse form for the novelle, and here he takes a position somewhat different from that of A. W. Schlegel, who had discarded verse altogether as a non-realistic and therefore unsuitable medium. Heyse does not fail to condemn the extreme devotion to the verse form soon after I850 as ,eine Verirrung des Zeitgeschmacks", and yet Hermann und Dorothea is a novelle in verse which is admirable in every respect, and Heyse himself had enjoyed considerable success in verse as well as in prose. „Sollte ich nun erklären, was diese kleinen Geschichten Besonderes hatten, das zur Ausführung in gebundener Form hindrängte, so ließe es sich am kürzesten so ausdrücken, daß sie schon im Stoff einen gewissen höheren po e t i s c h e n Reiz, einen idealen Zug hatten, der am glücklichsten in Rhythmus und Reim zutage treten konnte. ... . Im wesentlichen lief der Unterschied darauf hinaus, da $B$ das ursprüngliche novellistische Motiv zur Behandlung in Versen verlockte, da sein Reiz sich schon im Umriß, in wenigen andeutenden Zügen erschöpfen ließ. Sobald es

1) loc. cit. 82 . 
aber auf eine tiefere psychologische Durchführung, auf individuellere Charakteristik und schärfere Lokalfarben ankam, wurde es nötig, sich realistischer Darstellungsmittel zu bedienen, die nur im Prosastil zu Gebote stehen"1). In the last analysis A. W. Schlegel and Heyse stand on the same ground; prose is the medium for the serious novelle because it is essentially realistic.

Heyse's final word on the theory of the novelle, which first appeared in the last edition of the autobiography (I9I2), shows him still absolutely faithful to the principles which had governed him in the composition of his first novellen sixty years before. Here the appreciation for the work of his lifelong friend, Theodor Fontane, rests in great measure upon the fact that Fontane's realism was not of the sort that lays all emphasis upon what is ugly and repellent in life: „Was auf dem Gebiet der bildenden Kunst den alten Schadow so gro $B$ gemacht hat und später in Menzel aufs höchste gesteigert worden ist, ein idealer Wirklichkeitssinn, eine Verklärung des Nüchternen und zuweilen höchst Prosaischen, die wieder einen Eindruck hoher Kunst machen, den coin de la nature vu par un tempérament zu etwas unendlich Wertvollem zu erheben - vorausgesetzt, daß das Naturobjekt nicht völlig gleichgültig oder gar abstoßend ist, war auch Fontane eigen"2). But for all his realistic talent Fontane lacked that fine sense of selection, which to Heyse's thinking is a sine qua non for any poet, but particularly for the writer of novellen: „Diese beiden Gaben, die er im höchsten Maße besa $B$, scharfe Beobachtung des Lebens und die Fähigkeit, das Erlebte und Geschaute in reizvoller Lebendigkeit darzustellen, kamen ihm auch für seine Romane und Novellen zustatten, so $\mathrm{da} B$ er bald ..... zu einer führenden Stellung unter den zeitgenössischen Erzählern gelangte und heute als das glänzendste Talent der neuen realistischen Schule anerkannt wird.

Hier aber gingen unsere Wege auseinander. Da ich von einem novellistischen Kunstwerk oder einem Roman einen höheren Begriff hatte, als daß es sich dabei nur um eine interessante Darstellung des vielgestaltigen Menschenlebens handle, um gut erzählte Geschichten, wie sie eben im bunten Wechsel sich oft zu ereignen

1) loc. cit. 86 .

) op. cit. I, 93 . 
pflegen, nicht um bedeutende Fälle sittlicher oder geistiger Konflikte, in denen wir daran teilnehmen, wie sich irrende und strebende Sterbliche mit ihren größeren oder kleineren Schicksalsaufgaben abfinden, konnte mir eine Dichtung nicht genügen, der jeder coin de nature gleich wertvoll war, wenn er nur Gelegenheit bot, von irgend einer malerischen Seite aufgefaßt zu werden. Das Gemeine wurde als ebenso wichtig, wie das Edle, das Alltägliche so berechtigt zur Schilderung, wie das Seltene und Bedeutende betrachtet, das Kranke und Abstoßende sogar gegenüber dem Gesunden und Erquicklichen bevorzugt, da es an pathologischem Reiz diesem überlegen war. .... Während man dem Erzähler folgte, war man im Bann seiner großen plastischen Kunst . ... . War er zu Ende, so fühlte man, daß all seine Kunst nichts Bleibendes, Nachwirkendes in der Seele zurückgelassen, da keine tiefere Idee - wenn das von den Naturalisten belächelte Wort hier einmal gebraucht werden mag - die Handlung zu einer Art organischer Einheit zusammengefügt hatte. Alles war damit erschöpft, daß man wieder einmal Zeuge gewesen war, wie es eben in der Welt zuzugehen pflegt"1).

However unmodern Heyse's attitude may seem, it should not be forgotten that he had stood firmly for form, both in theory and in practice, for over half a century, through all the various phases in the development of a literature which has always laid the emphasis rather upon content than upon form. Heyse aspired to a harmony between content and form, and he had been considerably embittered by the savage attacks made upon him during the sway of naturalism after $\mathrm{r} 88 \mathrm{o}$. This may in part excuse the fashion in which he seizes upon one of the weakest of Fontane's works in the matter of form, Irrungen Wirrungen, and shows that it is not a novelle at all, with the implication that Fontane everywhere lacked that sense of form which is indispensable to the author in this domain of literature: Heyse's first objection is that the story lacks characters that are either novel or individual: ,Weder der junge Baron noch das Gärtnerskind haben sich selbst oder uns etwas zu sagen, was über das Alltäglichste hinausginge, sie sind beide völlig unbedeutende $\mathrm{Na}$ turen, an denen nur die Jugendfrische und äußere Gestalt an-

1) loc. cit. $94 \mathrm{f}$. 
ziehend erscheint, eine Art beauté du diable." What is worse, there is no plot to speak of, and what little there is shows neither novelty nor individuality: ,Aber wenn ein Dichter dieses tausendfach sich ereignenden Falles sich bemächtigt, erwarten wir, $\mathrm{da} B$ es nicht bei der Konstatierung der Tatsache bleibe; daß noch irgend etwas geschehe, was diesen Fall interessanter mache, als tausend ähnliche, ihm einen gewissen sittlichen Wert verleihe. Beide haben nach der Trennung geheiratet, der Baron ein Fräulein seines Standes, das er nicht sonderlich liebt, das Mädchen einen widerwärtigen Menschen, gegen den sie sogar einen stillen Abscheu empfindet. Sie wünschte eben versorgt zu werden. Aber jetzt - jetzt wird doch noch etwas kommen, ein Wiedersehen wird irgendwie stattfinden und vielleicht sogar eine Katastrophe herbeiführen, bei der es zu irgend einem Konflikt käme? Die eigentliche Novelle wird jetzt erst beginnen und zu irgend welcher Höhe gelangen? Nichts derart! Denn in der Wirklichkeit pflegt es dabei zu bleiben, daß eine solche Liebschaft keine Fortsetzung hat ...."1).

In a word, the story has neither silhouette nor falcon, neither an interesting and unusual central theme nor action which focuses entirely on this theme. Without going into the respective merits of "art for art's sake" and naturalism, one can grant Heyse his contention that this particular story is not a novelle, whatever else it may be. If the matter of form has any meaning at all for literature, Heyse has given an excellent working definition for a certain literary species in which he was an acknowledged master. On the formal side Fontane's story has sinned against the postulates of this definition at every turn. But one does feel in Heyse's case that emphasis on form had become overemphasis; that an innate, delicate, almost Romance sense of form. had grown over-sensitive, meticulous; that he, like Tieck, had outlived a present with which he could be in sympathy. When he saw literature apparently sinking again into formlessness, the only attitude possible for him toward the spirit of the time was one of violent reaction. It was his great loss that he was unable, not unwilling, to see the fruitful elements in the younger literary movement.

1) loc. cit. 96 . 


\section{Conclusion.}

When at the beginning of the Igth century the brothers Schlegel made the first serious attempt to define the term novelle, they were pioneers in more than the ordinary sense of the word, for theory is wont to follow in the wake of practice, and as a native German product the novelle, was as yet virtually non-existent. It is not surprising that the few of their predecessors, who had given the matter a thought, were agreed that the novelle was a condensed novel, or at least that the difference between the two forms was purely quantitative. Where only the German novel and the briefer prose tale of the I8th century are concerned, that idea is not altogether beside the point. But in the Decamerone and the Novelas exemplares the Schlegels had found a kind of story that had both high literary merit and a very definite form, and it is not by chance that the first important discussion of the species forms an appendix to Friedrich Schlegel's essay on Boccaccio.

Throughout the entire essay a comparison of the new form with the novel is not so much as hinted at, indeed it is compared with no other literary form whatever. It is a unique species and the critic is concerned only with its essence, not with any matter of outward form. Its most striking characteristic is novelty, if not in subject matter, then in treatment. In either case paradox is an element essential to this novelty $)^{\mathbf{l}}$. Since it is a finished literary product rooted in a highly cultivated society - and here there is an implied comparison with allied forms of more vulgar origin - its style will be that of the raconteur in distinguished company, the homo facetus of the Renaissance.

A little later (ca. r803-4) the elder Schlegel, who in his university lectures is addressing a more critical audience than the general public, went much more deeply into the theory of the species. He both enlarges upon the foundation furnished by his younger brother and brings entirely now elements into the discussion. In the first place he raises to prominence the inborn realism of the species and explains at length that prose is the

$\left.{ }^{1}\right)$ By paradox the Schlegels seem to mean a dénowement which the reader is not lead to expect from the beginning of the story. With Goethe and Tieck this is very evidently the significance of the term. 
essential medium for all that is realistic in literature. Within the bounds of realism it is peculiarly the task of the novelle to deal with events that are unusual to the point of uniqueness and yet of typical occurrence. All elements of the story that smack of the usual and ordinary should be only lightly touched upon in order that all emphasis may be thrown upon what is unusual. It is here that the idea of paradox becomes prominent: „Das Unwahrscheinliche darf dabei nicht vermieden werden, vielmehr ist es oft gerade das Wahrste". That is to say, what is unusual and unique may still be entirely realistic, and accordingly quite within the scope of the novelle.

The drama and the novelle have in common the elimination of all extraneous elements and concentration upon the problem in hand. „Möglich mag es vielleicht sein, alle Novellen zu dramatisieren," and farther than this Schlegel is not willing to go. But the novelle is definitely not a shortened novel, and the novel can not be dramatized successfully. Later Spielhagen carried this idea to its logical conclusion and made capability of dramatization one of two criteria which distinguish the novelle from the novel. Another element common to both the novelle and the drama is the need of "decisive turning points" which help along the action and obviate the necessity of full motivation, which is reserved for the more leisurely development of the novel. Finally the manner of the cultivated story teller in polite society furnishes the novelle a model in style.

Goethe's famous definition of I827: „Was ist die Novelle anders als eine sich ereignete, unerhörte Begebenheit?" is only the quintessential result of his investigation into the nature of the species, not a formal statement of its theory. In its beginnings this investigation antedates even that of the Schlegels. Like theirs, it owes its inspiration to the study of models furnished by the Romance literatures. As early as I795 the novelle had already taken shape in Goethe's mind as a story which is unusual within the limits of real life, whose novelty must lie either in the theme or in its treatment, whose theme is single and epoch making for the action, and whose structure should approach the unity of the poem. Theoretically emphasis is laid on the high social origin of the species, and in practice Goethe agrees to the Schlegels' 
doctrine of the cultivated raconteur. In one novelle of the Unterhaltungen Goethe is conscious that chance enters organically into the structure of the story, and he deliberately allows it to play the role that Tieck would assign to the "turning point" and Heyse to the "falcon". In $\mathrm{r} 797$, in his correspondence with Schiller, Goethe first touches explicitly upon the element of paradox in the novelle, and this point receives greater emphasis in the introduction to the story of Die wunderlichen Nachbarskinder (1809) and in his conversations with Eckermann regarding the composition of the Novelle (I826-27). It is here that Goethe states, in agreement with A. W. Schlegel, that prose is the necessary medium for the realistic. He nowhere discusses the relation to allied species except when he writes Schiller that he fears his "Jagd" may finally take the ballad form.

Tieck, on the contrary, is intent upon drawing a sharp line of division between the novelle and the briefer epic forms in-particular. In structure the novelle must concentrate upon a single event, and Tieck's is the first statement to place due emphasis upon the singleness as well as the singularity of the central theme. The elements of paradox and novelty lie in a single "turning point", which gives the action a new direction leading to a conclusion that the beginning of the story has not led the reader to expect. The "turning point" gives character to the novelle in a double sense: it sets this species apart from every other and it gives each separate specimen its individuality. Tieck had shared with the other Romanticists their characteristic longing for a Golden Age long past, but this conception of the "Wendepunkt" is now so fundamental with him that it reconciles him with the present by enabling him to see how the marvelous has never been lacking in any age. Accordingly the present day is as worthy of poetic treatment as any other epoch, and here Tieck's realism makes him a forerunner of Young Germany. Since the novelle deals with what is both actual and unusual, it must often treat of the abnormal, and for that reason it should not be held too strictly to conventional standards of conduct. Indeed the great raison d'être of the species lies in the fact that its field is outside the limits of the normal and typical; and so it enlarges the scope of 
literature by cultivating a field which is left untouched by the other great literary genres.

The first critic to base his theory of the novelle almost entirely upon a comparison with that of the novel was Theodor Mundt (I833). He likens the structure of the novel to a straight line which begins and ends more or less indefinitely; that of the novelle to a circle drawn about a center which controls the course of the line at every point and determines the end absolutely. The novel is a series of events, with one of which it closes; the action of the novelle is concentrated upon a central theme which imperatively demands one certain definite close and no other. The two forms are so different in their very essence that the question of bulk is of absolutely no importance. Another essential difference between the two forms is that the novel develops its characters, while the novelle simply shows how an already fixed character acts and reacts under the impulse of that with which it comes in contact. A. W. Schlegel had already touched upon this difference in tentative fashion, but Mundt develops it definitely and gives it considerable prominence in his theory of the two forms. Of later critics Spielhagen alone has given the idea considerable prominence: it is the second of his two main criteria for distinguishing the novelle from other forms. The first was capability of dramatization, but this idea did not come from Mundt, who like Tieck compares the novelle with the drama only for the sake of emphasizing points of difference.

During the Young German régime (ca. I834-50) the theory of the novelle floundered about in the dark, chiefly because it was found impossible so to expand the theory of a very definite form as to make it cover a formless literary product. Hettner's restatement ( 1850 ) of Tieck's theory of the novelle added a brief but adequate differentiation between the novelle and the novel. This definition is remarkable chiefly for its absolute clarity and keen penetration to essentials after a long period of aesthetic chaos.

In Heyse's Falcon Theory finally (I87x) the theory of the species found the first statement which has met with general acceptance in all quarters. It carries with it the authority of a recognized master in the genre it defines, but this would not have- 
been sufficient to give it lasting popularity, had it been based to any considerable extent upon the practice of a single author, as is the case with Tieck's definition. Outwardly it bears a strong resemblance to Mundt's theory in contrasting sharply the novelle and the novel; and Heyse's conception of the silhouette is very similar to Mundt's circle. However the simile of the silhouette is superior to that of the circle, in that it can not be misunderstood as implying that the action should move in a circle and end where it began. And Heyse's definition of the novel is more specific than Mundt's. It is doubtless as definite as any inclusive definition of this species can be made as yet $^{1}$ ). Heyse's "falcon" is only partially to be identified with Tieck's "turning point". For one thing it is not made to include the idea of paradox, an element which Heyse nowhere specifically mentions. Ultimately however the function of both is the same: the "falcon" like the "turning point" is the very quintessence of the individual novelle; it includes the element of novelty, and it is the one characteristic of the species to give it a unique position in literature. Like Mundt, Tieck and Goethe, but unlike A. W. Schlegel and Spielhagen, Heyse does not discuss elements of similarity in the drama and the novelle, though in passing he more than once drops a hint as to a certain resemblance between the two forms. Mundt's conception of fixed and developing characters, though it found such favor with Spielhagen, is not met with in any of Heyse's various statements. Either he considers the question non-essential or he avoids the issue. Certainly a novelle like C. F. Meyer's Der Heilige would present great difficulties to a critic attacking the problem from Mundt's standpoint, but it yields readily to classification under the silhouette-and-falcon theory.

In one point Heyse is explicitely in disagreement with his predecessors: in content the novelle must submit to a sharp

1) Cf. Hermann Herrigel, Novelle und Roman, Lit. Echo, XVI (15. Okt. I9I3), 8I ff: „Erst jetzt gestehen wir uns, daß der Roman als solcher keine Kunstform ist, da er keine innere, ihm eigentümliche künstlerische Einheit besitzt. Die Novelle ist in sich selber abgeschlossen, aber dem Roman fehlt das Prinzip, durch das er sich zum Scllusse rundet wie ein Kreis." For his theory of the novelle Herrigel owes an unacknowledged debt to Mundt. 
check at the dividing line between the beautiful and the ugly, the healthy and the pathological. This is a limitation which the novelle of the present day does not recognize as binding. And since Heyse would impose this limitiation not on the novelle alone, but also on all literature, we should do best to disregard it as an unessential element of his theory, which is so excellent as regards fundamentals.

Otherwise Heyse's sense of selection was of great benefit to him in the formulation of his theory. With admirable judgment and tact he has discarded non-essentials and thrown proper emphasis upon the elements he has retained as really fundamental. Without any thought of disparagement it may be pointed out that Heyse borrowed what he needed from his predecessors and shaped their thoughts to his purpose without the addition of any important new element. His theoretical statement is thoroughly eclectic, but critically so, and he constantly tests it upon the classic exemplars of the species he is attempting to define. With real discernment he casts the absolute essentials into a mold which is both striking and self-explanatory. In a statement which is the extreme of brevity and clarity his theory has met with a general comprehension and acceptance that had never fallen to the lot of any previous statement.

The question as to whether Heyse's is the definitive statement in the matter is doubtless futile. The trend of literary criticism today is all toward greater emphasis upon the psychological, and here, as always, criticism and theory have followed practice. One recent critic ${ }^{1}$ ) finds that the novelle has outgrown Goethe's definition by the substitution of „Einheit der Stimmung" for unity of action, that the form has developed along subjective rather than objective lines, as in Storm's novellen for example. But this is nothing new in literature: Tieck's Der blonde Eckbert, to cite a single example, aims at nothing less. Whatever may be the case with Goethe's definition, the application of Heyse's silhouette-and-falcon theory to Storm's masterpieces meets with no unsurmountable difficulty. This theory

1) Paul Joh. Arnold, Der Ausbau des Novellenbegriffs, Lit. Echo, XV (I5. Sept. 1913), 1676 ff. 
is by no means a theory of "outer", objective form alone; Heyse is very careful to specify an "Entwicklung von innen heraus". As yet the modern German novelle has not outgrown the Falcon Theory, and there is nothing to indicate a further devel-. opment on the formal side. To a psychological broadening and deepening of the content the theory would oppose no obstacle; it is sufficiently broad to include the best work of Boccaccio and Cervantes, of Storm and Keller. With the rise of realism all forms of art have been forced to work toward a compromise between an older form and an enlarged content, and in literature the novelle has had less difficulty in this respect than most genres, because realistic content has ever been one of its most characteristic elements. Many a story of real literary merit is a novelle only in name: why not grant it a right to existence along with the novelle? Why undo the critical work of a century to include a certain type of story under a rubric where it does not belong? The German novelle has won its way to prominence, like the American short-story, through its fidelity to a certain very definite form, and German literary critics and theorists would do well to take to heart the words of one of their greatest novellisten, Theodor Storm: „Die Novelle ist die strengste und geschlossenste Form der Prosadichtung, die Schwester des Dramas." 




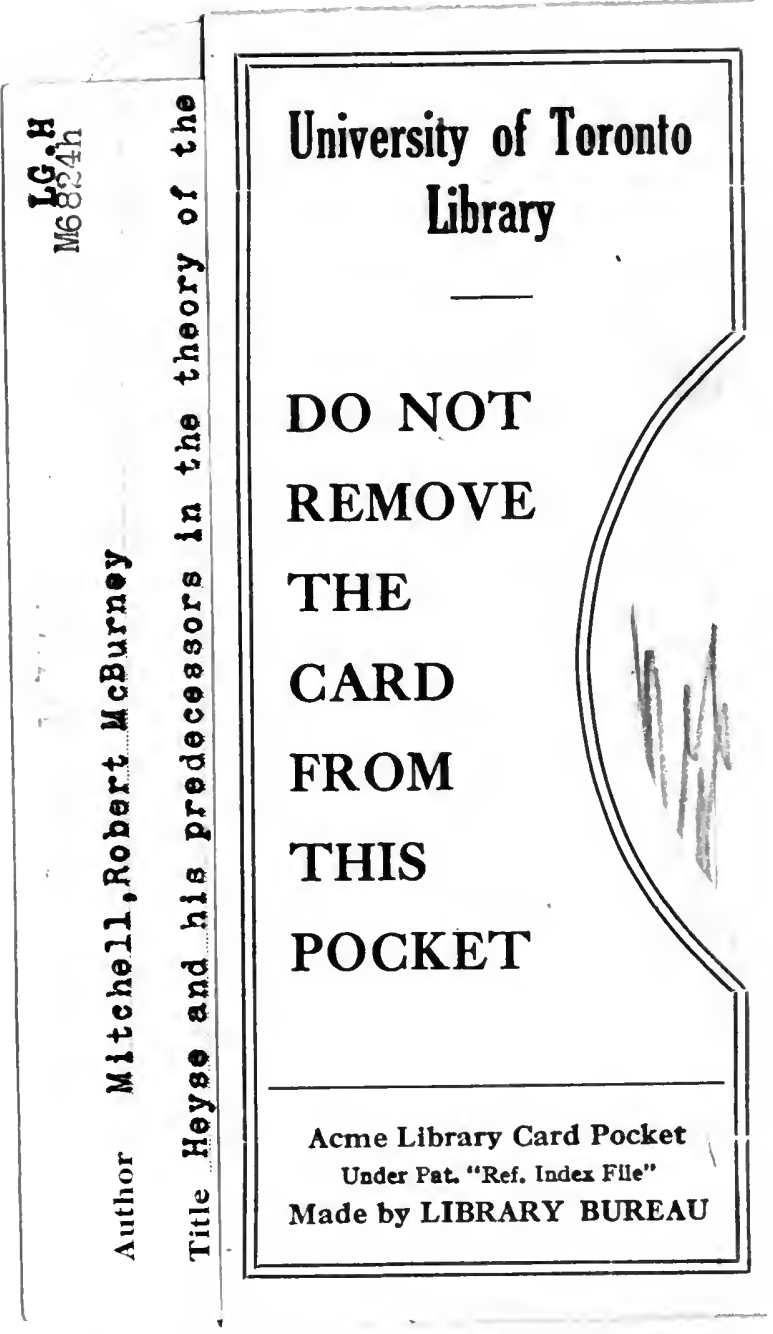


